Univa at

Tarome

Lotanghy 


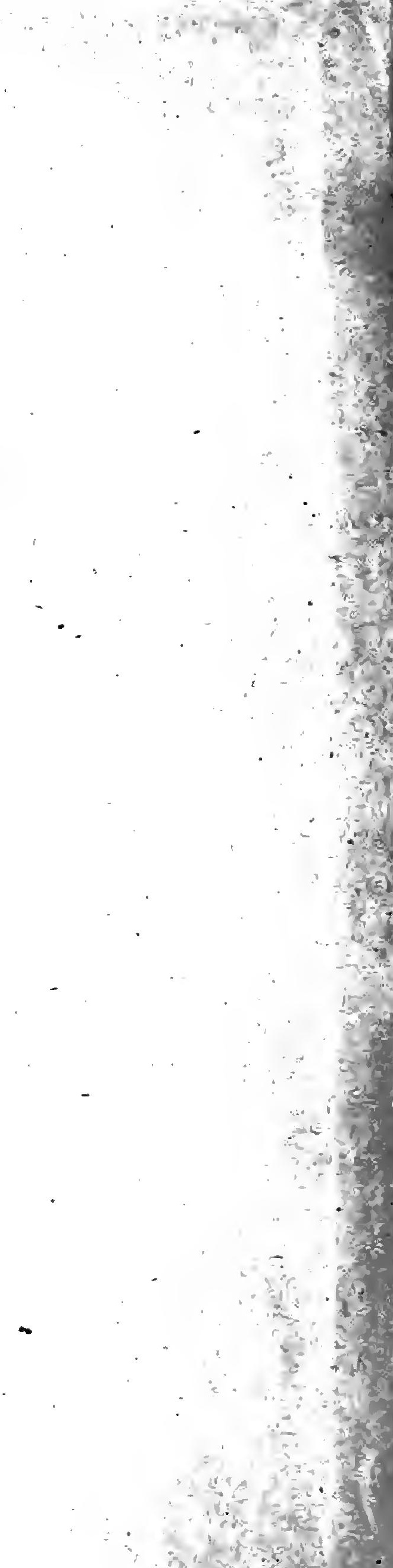




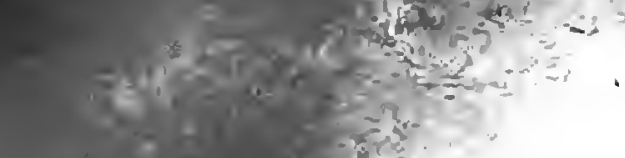

8.4

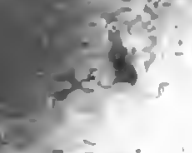

$\because+20$

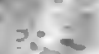

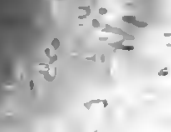

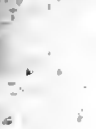

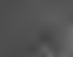

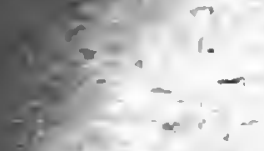

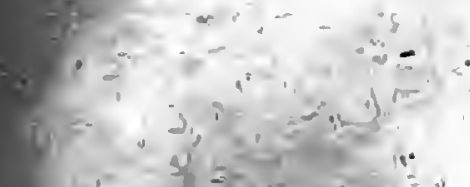

$i_{i=}^{2}=$

$y=y_{5}, \therefore \quad \cdots$

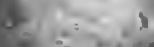

$x_{2} x_{0}+x$

Cois $: 5$

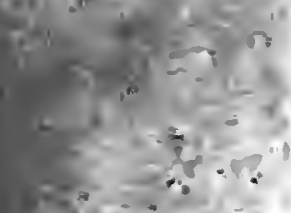

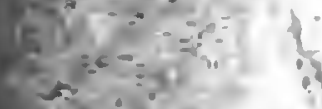

fing

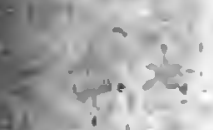

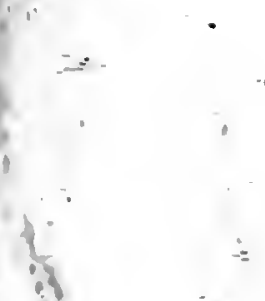

$3, x_{2}=$

if

(4). 10

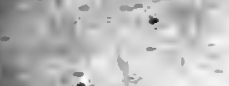

$\div$

Q.-?

S.

$-1,8 ?$

$a^{\circ}$ 


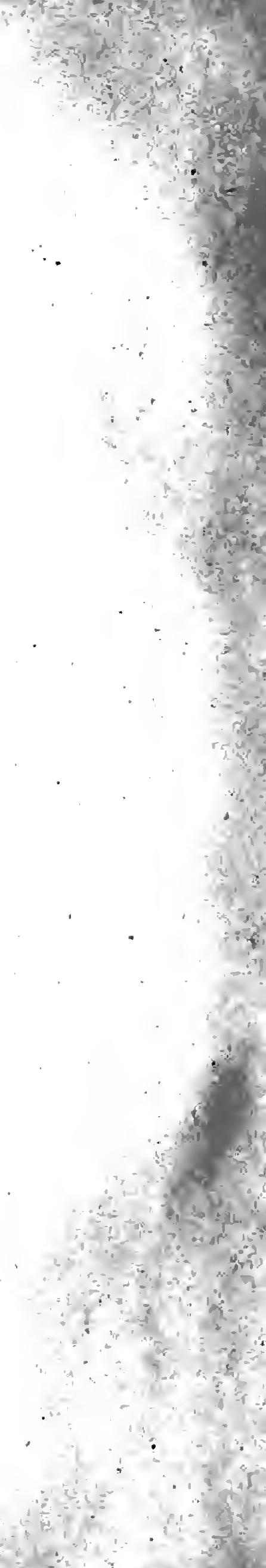


i

.- 


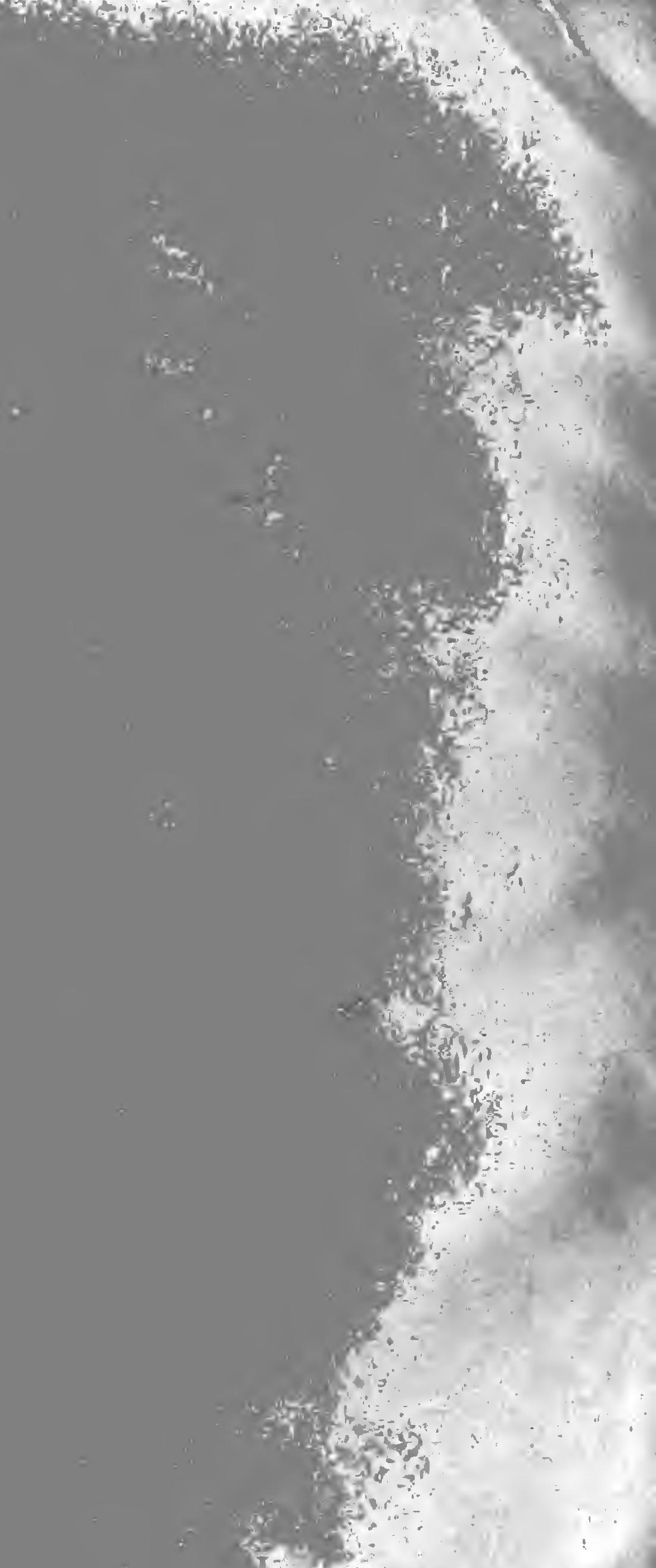




\title{
AMERICAN JOURNAL OF CARE FOR CRIPPLES
}

\author{
Published by the
}

JFederation of Associations for Cripples

EDITED BY

\section{Douglas C. McMurtrie}

EDITORIAL BOARD

Gwilym G. Davis, M.D.

Hastings H. Hart, LL.D.

Russell A. HibBs, M.D.

Artuur J. Gillette, M.D.

KonRad BIEsalski, M.D.
Charles H. Jaeger, M.D. Robert W. LOVETT, M.D. H. WINNETT ORR, M.D. John Ridlon, M.D.

RoberT JONES, F.R.C.S.

\section{PUBLICATION COMMITTEE FOR THE FEDERATION}

Miss Adelatde B. Baylis Mrs. Henry B. Barnes
Mrs. Helen K. Travers

Mrs. George F. Shrady

\section{Volume I}




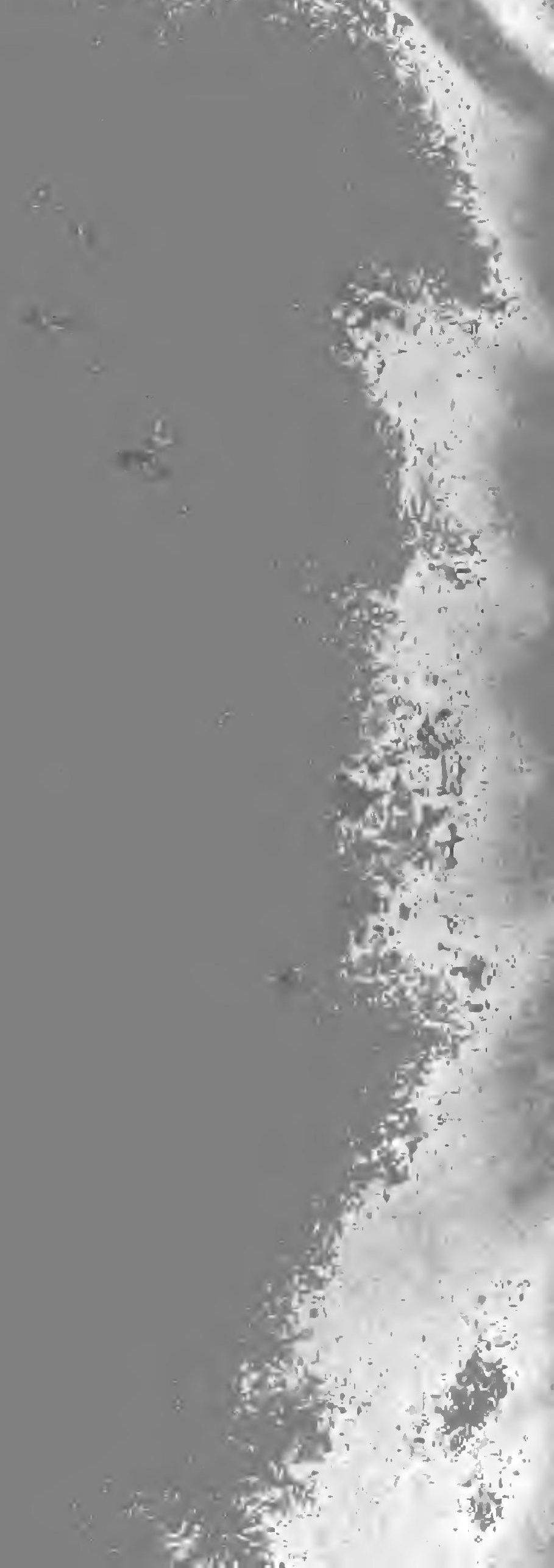




\title{
AMERICAN JOURNAL OF CARE FOR CRIPPLES
}

\author{
Published By the \\ JFederation of Associations for Cripples \\ EDITED BY \\ Douglas C. McMurtrie \\ EDITORIAL BOARD \\ Russell H. Hibis, M. D. Robert W. Lovett, M. D. \\ Charles H. Jaeger, M. D. H. Winnett OrR, M. D. \\ Konrad Biesalski, M. D. Robert Jones, M. D. \\ PUBLICATION COMMITTEE \\ FOR THE FEDERATION \\ Miss Adelayde B. Baylis. Mrs. Helen K. Travers. \\ Mrs. Henry B. Barnes. Mrs. George F. Shrady.
}

\section{Volume I Number I}

NEW YORK

I 9 I 4 
AMERICAN JOURNAL OF CARE FOR CRIPPLES

VOLUME I. NUMBER I.

NEW YORK, I9I4.

\section{CONTENTS.}

Federation of Associations for Cripples . . . . . . . . . 3

The education of crippled children. GwILym G. Dav1s . . . 5

Industrial training for crippled children about Boston. AugusTUS THORNDIKE . . . . . . . . . . . . . . . I4

The history of the Federation of Associations for Cripples. Katharine W. A. Shrady . . . . . . . . . . . 2 I

Notes on the early history of care for cripples. Douglas C. MCMuRTrie . . . . . . . . . . . . . . . . 27

A statistical estimate relative to the number of cripples in the United States. H. WinnetT ORR . . . . . . . 43

A course in basketry and cane-seating. GRACE F. HARDY . . 45

Contributed Notes . . . . . . . . . . . . . . . . 48

New work in Brooklyn, Walter Truslow.-Central States Orthopedic Club, H. Winnetr OrR.-The New England Peabody Home, Clara M. Thurston.-New Building for Nebraska Hospital, H. WinnetT OrR.-Mutual Alliance in Cleveland, Marion A. Parsons.-A system of industrial education, LILIAN GILBERT FISH.-Trade classes of the Brearley League, Louise BALDwIN.

Editorial Notes . . . . . . . . . . . . . .

Public School classes in Chicago.-The first state institution for cripples.-A Philadelphia report.-Institution for negro crippled children. - Hospital social service for cripples.-Driving fund for crippled children.-The magazine of an organization.-Other institution organs.An anniversary celebration.-Provision at Atlantic City.

Editorial office, 298 Metropolitan Tower, New York City. .

Application for entry as second class matter at the New York postoffice pending. 


\section{FEDERATION OF ASSOCIATIONS FOR CRIPPLES}

Organizations Members of the Federation

Brearley League Industrial School for Cripples

Crippled Children's East Side Free School

Miss Spence School Society

HARLEM DAY HOME AND SCHOOL

Association for the Aid of Crippled Children

Trade School of the Hospital of Hope for Injured and Crippled

Association of Public School Teachers of Crippled Children

in THE City OF NEW YORK

House OF THE HOLY COMFORTER

New York State Branch of the Shut-in Society

Ethical Culture Visiting Guild for Crippled Children

Women's Auxiltary of the Orthopedic Ward of the Post Graduate Hospital

CRIPPled ChildRen's Driving Fund

Daisy Fields Home and Hospital of Englewood

Darrach Home for Crippled ChILdREN

Brooklyn Home for Blind, Crippled and Defective Children

Free Industrial School for Crippled Children 


\section{FEDERATION OF ASSOCIATIONS FOR CRIPPLES}

\section{President}

Mrs. George F. Shrady

Vice-President

Mrs. Henry Goldman

\section{Treasurer}

Mr. Thomas S. McLane

\section{Executive Secretary \\ Miss Eva W. RoRTy \\ Honorary Vice-Presidents}

The Rt. Rev. David H. Greer Mr. William Jay Schiefrelin

Mr. Robert W. De Forest Prof. Edwin R. A. Seligman

Mr. Edward T. Devine Mr. Oswald G. Villard

Mrs. Joseph B. Greenhut - Miss Lillian D. Wald

Mrs. Florence Kelley Mr. Alfred T. White

\section{Executive Committee}

Mrs. Albert Seligmann, Acting Chairman

Miss Eleanor H. Adler

Mrs. Spencer Lathrop

Miss Adelaide B. Baylis

Mr. Thomas S. McLane

Miss EDith M. Bond

Mrs. John M. Galloway

Mrs. Henry Goldman

Mrs. Richard W. Mead

Dr. Charles H. Jaeger

Miss Eva W. Rorty

Mrs. George F. Shrady

Mrs. Ernest Strauss

Miss Florence S. Sullivan

Shop Committee

Mrs. Albert Seligman, Chairman

Miss Louise Baldwin

Mrs. John M. Galloway

Dr. Charles H. Jaeger

Mrs. Moses Heinemann

Mrs. SPEnCER Lathrop

Mrs. Charles E. Merrill

\section{Publication Committee}

Miss Adelaide B. Baylis, Chairman

Mrs. Henry B. Barnes Mrs. Helen K. Travers

Mrs. George F. Shrady, ex-officio

Legislation Committee

Mrs. Henry Goldman, Chairman

Dr. Charles H. Jaeger 


\title{
THE EDUCATION OF CRIPPLED CHILDREN
}

\author{
Gwilym G. Davis, M.D. \\ Philadelphic
}

When it was suggested that I address you ${ }^{1}$ on the subject of the education of the crippled my first inclination was to decline because I felt that I had not given sufficient attention to it. It is a subject, however, that appeals to me so strongly and seems to be in such an unsettled, early and primitive stage that I thought it best to do what little I could to aid in its discussion and further its progress.

Educators and the general community have not succeeded in establishing any standard for the education of the normal child, and yet we, have not only the problems of general education to deal with, but, in addition, those arising from the crippled condition of the scholars. It is evident that the methods employed in the two classes of cases must be different. It is perhaps recognized that to keep normal people well, exercise and hard work are desirable agents to employ. They can not only endure being driven but they actually flourish under it, but when a person is sick and diseased then rest and soothing and supporting measures are needed. Crippled children seem to me to constitute a sort of middle class, we should not drive them as we would the totally well children nor nurse them as we would the sick ones. In other words, they should have a distinct, separate, special method of treatment of their own adapted to their peculiar needs.

The education of crippled children is intimately associated with their bodily care. The two cannot be separated but must

Read before the Orthopedic Section of the New York Academy of Medicine, December 4, 1913. 
be considered together. We therefore find that we are confronted with the following problems-(r). Their maintenance, (2) the care and treatment of their disabilities, (3) their general education, (4) their character formation or moral education, (5) their vocational training and, finally, (6) their later supervision. While some of these can be isolated and treated more or less alone, as a rule, several of them will have to be dealt with at the same time; this of course adds to the difficulties. To conquer a difficult subject it is well to analyze or dissect it and attack it in sections. To let us begin with the subject of maintenance.

I. Maintenance. Maintenance has to do with the method of living and support of the child. It is influenced by its financial position. The children of the well-to-do usually have those interested in them that have both the ability and desire to see that they are well taken care of in all respects. They do not become public charges and do not frequent our charitable institutions; therefore, for the present at least, we can leave them and confine ourselves to those less favored. It is the poor child that is to be considered. These constitute by far the greater number of the crippled. How shall they be taken care of? We know that their home conditions are such that in many cases it is absolutely essential that they be removed elsewhere. It is generally recognized that it is best for the child to live in its own home provided it is a good home but many of these children are orphans, with no home at all, others have dissolute parents. These and many other reasons necessitate that the child be maintained elsewhere if it is to be made a fairly useful member of the community and not become a burden and public charge. The number of cripples is so great and their education and maintenance so expensive that in the present state of society it has been found necessary to establish institutions for them. While the substitution of an institution for a home is admitted by all as an undesirable thing from many points of view, still in somecasesitseems to be the only solution that we have at present. 
In the dim future I believe cripples will be provided with true home life, but in the meantime it is our duty to see that our institutions resemble the home as much as it is possible to have them. Bodily health has considerable to do with mental development. The inmates of our institutions are usually sufficiently well fed but it is different with those living in their own home. For these some sort of Social Service is necessary so that the food and home surroundings of the child may be improved. When the child attends a day school it has now become the custom in some schools to provide it with suitable nourishment, lunches, etc., which tend to improve and conserve its bodily health. I an convinced that the question of maintenance should be better looked after than was formerly the case. We owe more to the child than simply to furnish it with a brace, and I look for a great field of usefulness in our modern Social Service to enable us to meet this need.

2. Disabilities. If a child can walk to school the problem of its education becomes simplified. If a deformed hand is bettered it may be able to work, therefore orthopedic treatment is of the first importance. The more successful it is the broader is the child's sphere of capabilities. For this reason it is essential that institutions for crippled children should be so equipped as to provide the constant orthopedic treatment that these cases require. Even in the day schools there should be some one capable to do the more simple dressings and adjustment of apparatus that may be needed. The orthodox orthopedic hospitals may relieve the educational institutions of a certain portion of this work but never of all of it. It is, however, just as bad for a school for crippled children to be exploited by ambitious operators as a hospital as it is for a hospital to be allowed through incompetence and neglect to degenerate into a low grade home.

3. General Education. The crippled child has a greater need of a good elementary education than has a normal one. A normal child, owing to the possession of all of its faculties, has a 
greater opportunity of acquiring knowledge; a normal child can run around and almost insensibly imbibe knowledge that a crippled child has to have brought to it. For education to be successful one should not forget that it should be sufficiently thorough for the child eventually to become, to at least some degree, self-supporting. The wider the education the greater will be the choice of vocations in later years. For a cripple to be a bookkeeper it is necessary that he should previously have learned to read and write. In these days when professional educators are at variance as to methods we need not take time to discuss them, but we can all agree that what has been called a "common school" education is just as essential to the cripple as it is to the well child. If the state pays for the instruction of the latter it should also contribute for the former. Parents especially are apt to be neglectful and allow a cripple to grow up ignorant. It is our duty to teach them the error of their ways. Family teaching is of the greatest value. There used to be a lot of time lost by the child being in the hospital but we are now remedying that by having teachers come daily into our wards and instruct the patients. To care for the out-patients we have our social workers and our day schools to which the children are brought and from which they are taken back to their homes. Only recently in our city has the public school system provided special facilities for the education of crippled children but it is making good progress. It is not possible to teach cripples in the same manner as well children. They are so few in number, comparatively, and their disabilities so various that it is necessary to devote a large amount of individual attention to each child. Therefore, there should be a larger number of teachers than is necessary in our ordinary public schools. The classes should not be so large.

The question of age here demands consideration. The objection of attempting to instruct a very young child is that it is apt to be so conducted as to prejudice its general health and physical development. We must decide as to when it is best for an in- 
dividual child to sacrifice a certain portion of its outdoor life for indoor instruction. How are we to look upon the kindergarten with its pupils, some of whom have not been long out of the diaper stage? Also the Montessori and Fröbelian methods? To my mind all these various educational methods have their special good points but we must exercise care in imposing them on the individual cripple. Even in a normal child it is frequently difficult enough to have it develop a normal body, and a cripple burdened with his infirmity demands still greater care and is not fit physically to be given instruction at so early an age as is the well child. A well-fed child living out of doors is my ideal. If you want a puppy to grow up to be a big, strong, healthy dog feed it liberally on table scraps and allow it to run at large. Mental pabulum will not make an emaciated tuberculous child strong. A word to the wise, however, is I think, sufficient.

4. Character Formation or Moral Education. While intellectual development is of importance it is insignificant as compared with good character. A cripple, like others more favored, may be well educated and intelligent but if his knowledge is not used rightly it is a detriment rather than a benefit to society. The problem is how to rear them so that they shall develop into industrious, unselfish, honest and reliable citizens. How can they ever be made to be self-supporting if they are lazy and unwilling to work? How can ambition be infused into them so that they will endeavor to help themselves instead of being content to be parasites on the body politic? How can they be made to view life in a broad, humanitarian way and not devote all their energies to satisfying their own selfish desires? A failure in the moral training of a cripple means the evolution of an individual, detestable in character, a menace and burden to the community, who is only too apt to graduate in to the mendicant and criminal classes.

There are, of course, many things which influence the formation of character. I think it is generally recognized that pre- 
cept or example is the most powerful. If we can surround the cripple with good associations we have the best possible guarantee that he will develop correctly. The greatest influence is exerted by good home life. Children are imitative and are impressed by the people with whom they come in constant contact. In a good home they are shielded from evil associates and influences therefore it is our duty, when possible, to see that the crippled child is not deprived of the benign influence of one or both loving parents. There are some misguided people who think that the best thing for the child is to take it away from its home and parents and rear it in some asylum or so-called "home." This is certainly a mistaken policy. To my mind public charities appear to be possibly necessary evils but evils nevertheless. It is my firm belief that no child should be placed in them that can with justice be kept out. It is far better if we must dole out charity to dispense it in the home. Aid the parents to take care of the child and aid them to educate it and not tempt them to desert it by offering to care for it in a public institution.

Unfortunately it is impossible to provide homes for all the crippled children which exist in our community. Perhaps this is a field of charity which has not been sufficiently tilled. Is not our age both thoughtless and selfish? Is not the public generally too much inclined to hand their charitable duties over to some organized body instead of performing them themselves? Is it not too much the habit for a person to donate a certain sum to charity and then feel that they have done all their duty? The poor do it just as do the rich. A poor person will give to another poorer one a few pennies and concern himself not at all as to whether or not that is the way the unfortunate one ought to be helped; and the rich one does the very same thing, only on a larger scale. While it is best to care for cripples at home, provided it is not vicious, still the number of cripples who lack proper homes either on account of the death of the parents or their deplorable environment and the difficulty of training them 
is so great that at the present time it seems almost a necessity for us to utilize as far as we can the many institutions which have been established for their care. In these institutions it seems to me that the main object should be character development and that the educational aim should be secondary. It is apt, however, to be just the opposite. It is too liable to occur that while great attention is paid to their schooling too little is paid to what might be called home influences. If an institution is going to stand in locus parentis then the greatest care should be taken to see that all the officials and teachers and employees,everybody who comes in contact with the children,-be of the best possible character so that as the child grows up he insensibly acquires the views and habits of thought which will best fit him for a future career. The children should not, so to speak, be handled in masses, but should be brought as far as possible into direct personal and intimate contact with their caretakers and teachers. These take the place of the lacking parents and form the best possible substitutes. It is obvious that this requires that the caretaker, of whatever grade, be a person possessing those peculiar qualities especially suitable for the purpose, and such people are not easy to find. The results, however, will be directly proportionate to the extent to which the teacher or caretaker fulfils these requirements, and surely the selection of such is worthy of most serious attention. If the necessity of character formation is borne in mind many ways will present themselves by which it may be furthered.

5. Vocational Training. Manual training is not necessarily vocational. Its primary object is developmental. It is to teach children to do things for themselves, to think and reason and accomplish something by their own unaided efforts; in other words, it promotes self-reliance and it has its place as an elementary training, whereas the vocational training ends the school period. Cripples, from the very nature of their disabilities, are debarred from many avenues of work; but if the desire to work is present the possible field of employment is so large and varied 
that something that is suitable to his capabilities can be found for almost every individual. I think it a mistake to restrict vocational training to a few stereotyped forms and confining all to a narrow choice. The probabilities of success are directly proportional to the liking of the cripple for the work that he has been taught to do. For this reason the greatest care should be taken to first find out what is most desired by the child and what he is best fitted for and then an effort should be made to fit him in that line. The resources of many institutions are limited and the choice may not be as wide as desired, but I am convinced that more can be done if greater attention is paid to this aspect of the subject. Why should we insist on making a bookkeeper of a boy who is especially gifted as a wood carver! Why make a bad stenographer out of a naturally good milliner or dressmaker? Where the institution cannot itself furnish the needed facilities they can of ten be found outside its walls. In private offices and workshops opportunities may be found if there is only someone who will interest themselves to do it. Here is a field for social service. Recently one of my worst paralytics so learned the trade of a jeweler and watchmaker. Another, eighteen years of age, is earning eight dollars a week by designing stamps for hosiery. And the field is limitless. I am convinced that suitable work, which is practically self-supporting, can be found for every cripple who is possessed of the proper character and desires to aid himself. Of course it is unreasonable to expect a tuberculous cripple to earn as much as a healthy individual, but I have seen so many cripples doing so much for themselves that I have great hopes for the future in this direction.

6. Subsequent Supervision. So many cripples as they approach maturity have lost their home ties that, if they are left to fight their way alone, they are apt to retrograde or fail entirely. They should be made to feel that there is someone who is interested in them and who is watching their progress. They should be encouraged to keep in touch with their alma mater until they have definitely established themselves and formed a 
circle of friends elsewhere. The adult cripple has been too generally treated as a pauper but, if through state aid or private beneficence, a crippled child has been reared and educated and fitted for the duties of life it is certainly our duty to give him that moral support that every beginner in the struggle for existence needs to enable him to safely pass over the bridge which connects the productive and the non-productive periods of life.

These are some of the problems we have to face in caring for crippled children. Time does not permit me to mention all, nor to go into details, but the subject is young. It is but recently that orthopedic surgery itself has become established; our methods of dispensing so-called charity are crude and often misdirected and social service with its great possibilities has just been born. In various localities the conditions are different and the methods vary, but we all have the same ultimate aim. In the institution with which I am connected, the Widener Memorial Industrial School for Crippled Children, it is endeavored to care for, educate and fit for the struggle of life one hundred children - and we are doing what we can. As time passes on its field will no doubt widen and with added experience we are, I feel sure, justified in looking forward to a fruitful future. 


\title{
INDUSTRIAL TRAINING FOR CRIPPLED CHILDREN ABOUT BOSTON
}

\author{
Augustus Thorndike, M.D. \\ Boston
}

Industrial training for cripples began in the vicinity of Boston when the Industrial School for Crippled and Deformed Children opened its doors in a modest way October 4, 1893, under Miss M. M. Perry, teacher, now superintendent. It was incorporated March 27, I894, for the purpose of promoting the education and special training of crippled and deformed childdren. ${ }^{1}$

Dr. Edward H. Bradford, of Boston, was responsible for its inception. 'Traveling in Italy during the summer of 1890 , he saw the institution for rickets in Milan and was inspired with the idea that the crippled children of New England needed a place where they could receive special care and industrial training to fit them for the struggle of life, for hunchbacks and boys with hip disease grew up too delicate to cope with strong healthy men in handling a pick and shovel. His idea was to teach them sedentary occupations which would be remunerative and he aimed to insure their receiving employment by training them to be exceedingly skilful and proficient. It was decided to have a day school, not a boarding school, in order to retain the influence of home and family.

In June, I893, Mr. G. A. Fleischer, of Christiania, Norway, was in Boston for a few days. His daughters conducted an industrial school for cripples, and he showed examples of the work of their pupils at a public meeting: this led directly to the

\footnotetext{
1 Read before the Orthopedic Section of New York Academy of Medicine, Decem-
} ber 4 , 1913 . 
opening of the Industrial School for Cripples in Boston, for an unexpected offer was made by a clergyman to provide quarters rent free in the basement of St. Andrew's Parish House.

After two years the school moved to a house on Turner Street, then to one on Newbury Street, and ten years later, to the present building, 24I St. Botolph Street, built from designs of Peabody \& Stearns, architects, at a cost of $\$$ r 59,000 .

The aim was ever that the chief duty of the school was to make the pupils breadwinners, not to allow them to be hidden away at home leading the lives of shut-ins, only to find themselves bereft of all when their parents died. To accomplish this, it was equally important to provide a grammar school education, and to make them proficient in an industry.

For the early training of the hands, certain forms of manual instruction are used;-clay modeling and paper sloyd classes and elementary basket work; needle work is taught by methods very similar to those at the Pratt Institute, Brooklyn. Cooking classes and wood sloyd follow upon the more elementary classes of manual training. Then advanced sewing, the caneseating of chairs, basket-making, cabinet-making, and the making of wooden toys, shoe repairing, type-setting and press work in the printing room. Other industrial branches will probably be added when the trustees are satisfied that they will prove useful to a large enough class of pupils.

A high standard of workmanship is maintained. To stimulate the children in the upper grades, a system was adopted of paying the pupil for work if it is constantly up to standard. The teacher is the judge of this. The first money earned is always a great stimulus, not only to better workmanship but to the mental development of the cripple, for it awakens a realization of his power to earn his daily bread unaided. This is furthered by the industrial department. It is a workshop for graduates and for other adult cripples unable to find employment outside. The department receives and executes orders for printing, dress-making, needle-work, baskets, cane-seating 
and simple cabinet work. The purchaser is charged in addition to the labor and materials a moderate profit, so that the finished article may cost what it would at retail. Except in the printing department, it is at certain seasons difficult to obtain orders enough to keep the pupils busy steadily. Therefore stock articles are made, to be sold at the annual fair, and for the last two years at a small shop in Manchester, Massachusetts, maintained by private enterprise during the summer season.

The graduates have an association which meets at the school each spring for social recreation and to keep up old friendships. It is interesting to learn from those attending of the successes and failures. But it is indeed seldom one finds any one who is not working steadily.

The Massachusetts State Hospital School for the Care and Education of Crippled and Deformed Children of the Commonwealth is a boarding school, under the charge of the state, and has just completed its sixth year of activity. In March, 1904, the Legislature authorized the expenditure of $\$ 300,000$, for the the purchase of land and the erection of buildings to accommodate three hundred pupils, and it placed the construction and adminstration under the charge of five trustees, appointed by the governor, one of whom retires each year. Dr. Edward $\mathrm{H}$. Bradford has remained chairman of the Board.

Sixty-five acres of land were secured in Canton, fifteen miles south of Boston. It is a wind-swept ridge, covered with scrub oaks and a small pine grove, bordering on an artificial pond, which Paul Revere made to supply power for a copper mill which he built at the close of the Revolution. The first children were received January 14, 1908; at the close of the first year one hundred and four children had been admitted, of whom eighty-seven remained in school. There has been a steady growth in numbers; there are now two hundred and sixty pupils. The superintendent and treasurer, Dr. John E. Fish, a native of New Hampshire, has done much to develop the school on original lines. He has had the assistance of an assistant super- 
intendent also a physician, and during the past year of another doctor as second assistant superintendent. The medical care is entirely in their hands, together with the administration; but there are also consultants.

The school instruction covers the first eight public school grades and there is a primary grade for beginners. Essentially the same ground is covered as in the public schools, but the sessions are shortened and the children divided into small groups. One hour and a half daily represents the school hours of the smaller children, and the older children have two hours Heal thy out-of-door life helps the child to concentrate his attention on his work and to complete it quickly. Vacations are few except public holidays, but each child goes home for two or three weeks twice a year. As soon as a child's health and disability so improve that he can safely attend public school his parents are asked to take him home. And it usually happens that a boy or girl returning after two years at Canton, is advanced a class ahead of his former classmates.

Except for sewing, which is taught in eight graded classes commencing with the stitching of samples and ending in the making of a dress, the instruction in industrial branches follows no set rules. The superintendents, the teachers and the attendants endeavor to become acquainted with each child separately to find out what interests him, what he keeps thinking about; and this, together with the example of others learning to work, is the incentive which leads a child to apply himself for his industrial instruction. When one of them comes to Dr. Fish and asks permission to join an industrial class, he receives deliberate and thoughtful consideration; he is asked what he can make, why he wants to try that particular kind of work; finally the superintendent either grants his request for a few weeks' trial or tells him that he will have to prepare himself in more elementary work first, and that he will arrange for that.

Dr. Fish is often asked: "What can a boy do who has a shriveled right arm and hand?" And he has come to answer: 
"First let me see the boy, let me know him a while, then I can tell you several things he can do." He believes that much depends upon a proper choice. The child's taste and the influences of home environment have to be respected. If a boy or a girl wishes to make a change in his or her industrial training, the same careful attention is bestowed.

The industrial training is taught in a practical way; there are no regular lessons in domestic science, in type-setting and printing, in shoemaking, in woodworking with machine tools; in the boiler room, and in the engine room, where they learn under the engineer. These opportunities are greatly prized by the older boys. Whenever one of the buildings needs repairs, these boys work with the resident carpenter or engineer or painter. They have recently had a chance to paint and glaze the window sashes and window frames of the new barn, and to shingle the roof and walls. The engineer teaches them to make orthopedic apparatus for the school, which with the help of their instruction in cobbling, they cover with leather and padding, and furnish with straps and buckles complete.

The farmer also takes group of boys under his care, learning about the live stock, horses, goats, pigs and chickens (cows are soon to be added). Another group goes to the garden and raises vegetables and farm supplies for the institution. One of them last year gave at the graduation exercises a bright practical discussion on the raising of chickens, based upon his own experience at school in poultry raising.

It is felt that much of this is really vocational instruction, that it should follow, rather than accompany, the grammar school course; but to this practical objections are of ten offered by the parents; in some cases the general health has improved so greatly that the disability is less of a handicap, and he is really able to return to high school to cope with normal children; at other times, the parents are unwilling to have the child remain longer away from home. So far it is often impractical to have vocational or post-graduate industrial pupils. 
The results of industrial training are only to be found in the lives of those who have gone out into the wide world. They are known only by isolated examples. But, all those who graduated last year are at work, excepting one bright girl with double hip disease, who wishes to be a teacher, and is taking the high school course, preparatory to the State Normal School Course. This experience, I believe, is shared in by all teachers of cripples outside of New England.

A fairer estimate of the industrial results would be the occupations of those who graduated five years ago, but these figures I have been unable to ascertain for either the Boston or the Canton school. There is no question but that the cripple finds it difficult to obtain employment and the reasons come both from himself and the employer. All the teachers realize the mental warp of the cripple, and struggle to overcome it. I believe that it arises from sensitiveness, fostered by misguided home influences, and it produces a fixed impression in the mind that "since I am a cripple, I am only an object of pity, so somebody will have to look out for me." At the Industrial School, in Boston, the money a pupil earns by his work does much to dispel this impression; for he knows that his normal friends of his own age cannot do that at their school, although their bodies are strong and healthy. This inspires him with self-confidence, even with a sense of superiority. But he may relapse and is especially apt to when looking for a job.

The employer too has difficulties on his side, largely the result of his own brain. When he sees a young cripple applying for work, he says to himself, "I cannot take that fellow, he is too sick, or he is too lame, or he is too deformed in appearance; he never could work." When we realize how great these difficulties really are, it seems wonderful that so many cripples are steadily employed.

Sometimes an advantage can be obtained in favor of a cripple applying for work if his application be made in writing, instead of by personal interview. It would be well, also, if local 
societies would interest themselves to secure employment for cripples. The social worker can do much in this line.

One of Boston's church clubs, the King's Chapel Club, has organized to secure employment for the handicapped, and employs a salaried social worker exclusively for that object. Under the term "handicapped" the blind and deaf are also included. The agent, Miss Harper, has many applications, but she finds it the part of wisdom to know both the employer and the cripple thoroughly, and only to apply for those who will be satisfactory. She has learned that it is only about one employer in ten who will take a cripple; seldom will more than one be accepted. It is to be hoped that the example of the King's Chapel Club will be followed by others, for this work is much needed to supplement what the schools are doing. It properly begins where they leave off, and without it many jobs will be lost unnecessarily and much discouragement ensue. 


\section{THE HISTORY OF THE FEDERATION OF ASSOCIA- TIONS FOR CRIPPLES}

\section{Katharine W. Ambrose Shrady}

The attempt to amalgamate the work of associations for cripples had its inception in 1908 when the Russell Sage Foundation through its Social Research Committee, co-operating with the Bureau for the Handicapped of the Charity Organization Society, began an investigation of the possibilities of employment for cripples. It was found that women and girls were quite well provided for, but for men and boys without technical training it was extremely difficult to procure employment. As the result of the investigation by this joint committee, an article by Miss Eleanor H. Adler and Miss Serena G. Marshall appeared in The Survey of April 30, I9Io, making a strong appeal for the establishment of trade schools for crippled men and boys. One of the best trade classes in New York was the outgrowth of this appeal, and since then another fully equipped trade school for men and boys has been established. It was also shown by this investigation, as well as by the practical experience of those actively interested, that overlapping and lack of co-operation prevented the attainment of the best results. There are many agencies doing friendly visiting in the city, and a crippled person being somewhat conspicuous, rarely escapes attention. It is a great waste of time and energy, and not productive of the best results, to have a number of persons giving advice to the parents of a crippled child as to its training and general treatment. It is also true, that there was little knowledge among workers as to what associations other than their own were doing to advance educational methods; also an absence of harmony in the interchange of 
information, between societies that might otherwise have been working together along progressive lines for the benefit of cripples. In this way associations frequently wasted valuable time dealing with problems which had been satisfactorily solved by others. There was no central bureau, where information could be obtained pertaining. exclusively to cripples. The logical and systematic way of meeting this want, was through a federation, as being better adapted to do such work than any other existing agency. It was therefore, in response to the wide-felt need for co-operation, that representatives of twenty or more associations met in New York in February, I912, and discussed plans for organizing a federation of associations for cripples. A committee known as the Amalgamation Committee was formed, which consisted of Miss Dorothy Bull of the Brearley League Industrial Classes for Cripples as Chairman, Miss Florence S. Sullivan and Miss Dorothy Truesdell of the same society, Mrs. Henry B. Barnes and Miss Edith M. Bond, of the Association for the Aid of Crippled Children, Mrs. Henry Goldman and Mrs. Moses Heinemann of the Crippled Children's East Side Free School, Miss Helen Sturgis and Miss Elizabeth K. Lamont of Miss Spence's School Society, Mrs. Ernest Strauss and Miss J. F. Benjamin of the Ethical Culture Visiting Guild for Crippled Children, Mrs. John M. Galloway of the New York State Branch of the Shut-In Society, Mrs. Spencer Lathrop of the Harlem Day Home and School, Mrs. B. E. Martin and Miss Spelding of the Darrach Home for Defective Crippled Children, and Miss Eleanor H. Adler of the Bureau for the Handicapped. During the ensuing year frequent meetings were held. A sub-committee, of which Miss Florence S. Sullivan was Chairman, was appointed to consider in detail, and report on the various phases of industrial training for cripples, the advantages and importance of a central shop for the sale of work-room products, and the advisability of allowing cripples to compete with regular factory workers, or work in shops by themselves. The committee suggested ways of 
improving the training of cripples for commercial and industrial life, and recommended the employment of an expert investigator who should report in writing from time to time upon all questions relating to the home life, work-shops, industrial schools, and eleemosynary institutions for cripples. As a result of these preliminary meetings, the Federation was formally established in January, 1913, and its first general meeting was held on the twenty-third of that month. The following April at its second general meeting, a Constitution was adopted and committees appointed. Officers were elected at the first annual meeting held December 10, I913.

The Federation began with fifteen of the leading associations and societies of Greater New York as members, and is in active co-operation with thirty-two other similar organizations.

Its general object is to co-ordinate the work of the various societies interested in cripples by the establishment of a central bureau, where a complete registry is kept of all homes, schools, hospitals, aid societies, fresh air agencies, and industrial schools, so that cripples may be referred there for information, if they require industrial training, positions adapted to their abilities, or work in their homes. An executive or field secretary is employed to investigate all cases that are brought to the attention of the Federation. She has also made a complete survey of the forty-seven institutions and associations in Greater New York and immediate vicinity which includes a history of the work carried on by each agency, and the number and kind of persons benefited. A list of summer homes and fresh air opportunities offered exclusively for cripples has also been compiled. The Federation is intended as a clearing house of information and a registration bureau, and is in no sense a relief agency. Its function is to refer persons to the organization best suited to their needs. Frequently the question is asked, "What benefit does an association derive by joining the Federation?" The greatest benefit outside of the varied in- 
formation which it classifies and places at the disposal of all, is the opportunity it affords of improving the general condition of cripples. It would be impossible for the earnest, experienced members of fifteen leading associations to meet and discuss plans and methods, without some advancement resulting therefrom. Organizations do not surrender any of their individual rights by federating, and their specific lines of work are conducted as independently as if they stood alone. Common-sense methods are followed, and only where benefit will result is co-operation desired. Federation has a tendency to broaden the attitude of those interested, so that instead of being devoted to one given line of work, they will endeavor more fully to help the individual cripple by placing him where he can derive the most benefit from the training he receives. For example, if a boy of artistic and technical gifts has been taught to embroider on linen, work of the very highest excellence, and it is discovered through the Federation that this boy can be taught the more suitable trade of engraving on copper, silver and gold, it surely is a step in the right direction to place him in the school where he may be taught engraving. In the short time that the Federation has existed, instances have frequently occurred where it was found advisable to transfer pupils from one school to another, better adapted to their needs. The possibilities of this have been learned through membership in the Federation. There will always be those who prefer not to unite with others to do the greatest good for the greatest number, for fear that they will not receive recognition or due credit, but the person who loves to work for cripples, primarily to help the individual, will not be restrained by selfish considerations from joining with others to accomplish this purpose.

The importance of a central shop where work done by cripples may be sold, has been strongly urged by those in charge of trade schools. It is conceded that at present there are difficulties which prevent the carrying out of such a plan. Schools, for instance, that are not endowed and depend for maintenance on 
voluntary support and the output of their work rooms, cannot afford to risk any diminution of revenue by an experiment of this nature. On the other hand, it is urged by those who advocate the central shop, that by requiring the workmanship to reach a certain standard of excellence, a larger market would be created, and thus through increased demand, loss from competition of individual schools, would be counterbalanced. Much benefit has thus far resulted from industrial exhibits under Federation auspices. This was satisfactorily tested in New York last December, when the industrial departments of six leading associations gave an exhibit and sale, of the output of their trade classes. At least two of the schools displayed art embroidery on linen and silk that is not surpassed by similar work in any other country. The effect of this excellence was to set a standard for other exhibitors which cannot fail to improve the quality of their work. Another significant feature of the combined sale, was the receipts of individual associations. In every instance they reached a perfectly satisfactory figure, and in the case of one of the largest schools, was several hundred dollars ahead of the amount customarily received from this source. It is felt therefore, that the central shop open for a period of several months each winter, if not all the year, will naturally be evolved from the combined sale and exhibition, given under social auspices for two successive afternoons annually. The value of the Federation to societies whose work is along purely educational and social lines, is the opportunity afforded at Federation Conferences, for the discussion of leading questions. The problem of separating and training mentally defective cripples is one that is brought home daily to teachers and managers of industrial schools. It has been a much discussed subject, presenting many dilemmas, but it is expected that a practical solution will be effected through the efforts of the Federation's Committee on Legislation, which is now studying the question. No greater opportunity has yet been offered the Federation to demonstrate its usefulness in a practical way. 
Although so much is now being done throughout this country and Europe to ameliorate the general condition of cripples by giving them special training to make them self-supporting, there has been an absence of literature relating to these subjects, mainly because no suitable mediums, such as a magazine or news bulletin, existed. It is with the intention of meeting this need that the American Journal of Care for Cripples, a quarterly magazine, is now to be published under the auspices of the Federation. By this means it is intended to keep informed, those who are seeking to improve the methods of helping their afflicted fellow-beings who are handicapped by accident or disease. To make the Journal successful the Federation bespeaks the support of those throughout the world, who are interested in bettering the condition of cripples. 


\title{
NOTES ON THE EARLY HISTORY OF CARE FOR CRIPPLES *
}

\author{
Douglas C. McMurtrie \\ New York
}

The cripple has long been considered, at least in literary fields, as the prototype of the handicapped and miserable creature. We may, therefore, expect a study of the history of the attitude of society toward the deformed to throw considerable light on the growth of a sense of community responsibility for the welfare of unfortunate members. The subject thus touches intimately the general history of medicine.

From the earliest times the lot of the cripple has been a hard one. The first mention of physical deformity carries with it stigma in other respects as well. With primitive peoples the cripple was very commonly exposed or abandoned to perish of neglect. ${ }^{1}$ Among Indian peoples the Chiriguana are reported as addicted to this practice. ${ }^{2}$ Waitz reports that the Salivas, like many others, are accustomed to destroy deformed children, since they attribute the deformity to the influence of evil spirits. $^{3}$ The same practice existed among the Carib tribes of the Antilles. ${ }^{4}$ Among the Aztecs ${ }^{5}$ deformed persons could be

- Reprinted by permission from the Johns IIopkins Hospital Bulletin, Baltimore, 1914, $x \times v, 57-62$. Article in that publication entitled "Early History of the Care and Treatment of Cripples."

1 Albert Hermann Post, Grundriss der ethnologischen Jurisprudenz. Oldenburg and Leipzig, I 894. Vol. 2, p. 10-12.

Thouar, Deulsche geogr. Bläler, vii, 66.

- Theodor Waitz, Anthropologie der Naturö̈lker. Leipzig, 1892, Vol. 3, p. 394. Also see A. O. Humboldt and Bonpland, Reise in die Aequinoctialgegenden des Neuen Continentes in den Jahren I790-1804. Stuttgart and Tübingen, 1845.

- Albert Hermann Post, Bausteine für eine allgemeine Rechtswissenschaft auf vergleichend-ethnologischer Basis. Oldenburg, 1880-1881, Vol. 2, p. 119.

- Joseph Kohler, Recht der Aateken, p. 46. 
sacrificed in time of famine and need. They could also be sacrificed at the death of kings and great men. Deformed infants were abandoned or killed by various tribes living on the islands of the Pacific; Australia, ${ }^{8}$ Hawaii, ${ }^{7}$ and others, ${ }^{8}$ as they were by some negro-pcoples as well. ${ }^{9}$ In the kingdom of Assinie on the Gold Coast, children with six fingers on either or both hands were buried alive. ${ }^{10}$ Among the Indo-Germanic peoples exposure of deformed infants ${ }^{11}$ was a custom of frequent occurrence. In the early law of Northern Germany the right to kill monsters and deformed persons is often mentioned. ${ }^{12}$

Isolated cases of the practice of the exposure of infants occur in Japan, ${ }^{13}$ as in other countries, but it has never approached recognition as a general custom. From the myth of the god Hiruko (leech-child) it may be inferred that the abandonment of deformed infants was not uncommon in the earliest times. The Nihongi tells us that the god had completed his third year and was still unable to walk. His parents, therefore, placed him in the rock-camphor-boat of heaven and set him adrift.

Data concerning the exposure of infants in Persia ${ }^{14}$ are scanty. According to the Avesta, ${ }^{15}$ all deformities were regarded as the work of the Evil One. It is not impossible, therefore, that deformed children were exposed with more or less frequency.

- Albert Hermann Post, Bausteine für eine allgemeine Rechiswissenschaft auf vergleichend-ethnologischer Basis, Oldenburg, 1880-1881. Vol. 2, p. I19. Also Joseph Kohler, in Zeitschrift für vgl. Rechtswissenschaft, vii, 355. Also Waitz-Gerland, Anthropologie, Vol. 6, p. 779.

Waitz-Gerland, Anthropologie, Vol. 6, pp. I39-140.

- Albert Hermann Post, Bausteine für eine allgemeine Rechiswissenschaft an vergleichend-ethnologischer Basis. Oldenburg, 1880-1881, Vol. 2, p. I I9.

- Albert Hermann Post, Afrikanische Jurisprudenz, Oldenburg. I887, Vol. I, p. 285. 10 Globus, I89I, No. II, p. I76, after Reichenbach, Étude sur le Royaume d'Assinie. Bull. Soc. Géogr., I89o, p. 3 I6.

1 Grim, Rechtsaltert, p. 456.

"Maurer, Wasserweihe des germ. Heidentums, r880, p. $44 \mathrm{ff}$.

"James Hastings, Encyclopadia of Religion and Elhics, Edinburgh, 1908. Vol.

I, p. 7. Article by W. G. Aston.

14 Ibid., Vol. I, p. 7, Article by Louis H. Gray.

36 Vendìdād, ii, 29. 
Among the Pima Indians, a North American tribe, with the consent of the parents, deformed infants were taken by the midwife, who watched them until they died of exposure and want of nourishment. ${ }^{16}$ So strong was the feeling of the Pimas against the abnormal that they tried in recent years to kill a grown man who had six toes.

In this connection, James Mooney of the Bureau of American Ethnology, in a communication to me, notes as follows:

Among the Kiowa I knew personally a twelve-year-old girl, of receding forehead and halfwitted, who had been buried alive immediately after birth and rescued and brought to the Catholic mission by a captive woman who knew what was about to be done. The missionary priest, from his experience waiting on their sick in camp, believed that they had killed other defective infants at birth. I know also of instances of abandonment of the helpless aged in the same tribe.

Travelers have asserted the existence of the practice of killing defective infants, in various tribes, and I am inclined to think that it was quite general. Some tribes, especially in Oregon, kill one of a pair of twins. The reason in both cases seems to have been partly economic, to be rid of a future burden, and partly from a superstitious fear of the abnormal.

With the dawn of our present civilization the condition of the cripple did not improve to as great an extent as we should ordinarily expect. Oriental peoples turned forth their cripples to wander in the wilderness. The inhabitants of Ancient India cast them into the Ganges; the Spartans ${ }^{17}$ hurled them from a precipice into an abyss, Apothetos. The Jews in the earliest times banished their cripples so that they had, perforce, to beg by the roadsides. The general attitude was to regard physical deformity as a blight sent by God or as a punishment for sin.

The Hebrew scriptures reflect the attitude that the deformed

16 Frank Russell, The Pima Indians. In 26th Annual Report, Bureau of American Ethnology. Washington, 1908, p. 185.

"Douglas C. McMurtrie, The Primary Education of Crippled Children, New York, 1910 , p. 5 . 
person must be spiritually and mentally unfit as well. In Leviticus ${ }^{18}$ we encounter a passage illustrative of this:

And the Lord spake unto Moses, saying: speak unto Aaron, saying, whosoever he be of thy seed in their generations that hath any blemish, let him not approach to offer the bread of his God.

For whatsoever man he be that hath a blemish, he shall not approach; a blind man or a lame, or he that hath a flat nose or anything superfluous.

Or a man that is brokenfooted, or brokenhanded,

Or a crooktbackt, or a dwarf, or that hath a blemish in his eye, or be scurvy, or scabbed, or hath his stones broken;

No man that hath a blemish of the seed of Aaron the priest shall come nigh to offer the offerings of the Lord made by fire; he hath a blemish; he shall not come nigh to offer the bread of his God.

Later on in the same passage it is stated that the reason for this is that the sanctuaries be not profaned.

There are references to the cripple in the Old Testament in the form of similes showing that physical deformity was familiar to the people. ${ }^{19}$ The first reference to a deformity caused by accident occurs in the Second Book of Samuel.

And Jonathan, Saul's son, had a son that was lame of his feet. He was five years old when the tidings came of Saul and Jonathan out of Jezreel, and his nurse took him up, and fled; and it came to pass, as she made haste to flee, that he fell and became lame. And his name was Mephibosheth. ${ }^{20}$

This accident was probably the forerunner of many subsequent accidents to children in charge of nurses.

Kindly references to the cripple in early times are scarce. In Job's recital ${ }^{21}$ of his circumstances when God was with him, recounting his various benevolences, he says, "I was eyes to the blind and feet was I to the lame."

\footnotetext{
"Leviticus, xxi, I6-21.

"See Proverbs, xxvi, 7 .

20 II Samuel, iv, 4.

« Job, xxix, 15 .
} 
In referring to inheritance, the Dâdistân-î-Dînîk, ${ }^{22}$ one of the Sacred Books of the East, ${ }^{23}$ says " . . . and the share of one of the sons, or even the wife of a son who is blind in both eyes, or crippled in both feet, or maimed in both his hands, is twice as much as that of one who is sound."

The Greeks, worshipping as they did the perfection of bodily form, regarded a cripple as the incarnation of everything unlovely, ${ }^{24}$ not only physically, but also mentally and morally. Homer describes Thersites as possessed of every ugly attribute and equally deformed in body and mind. ${ }^{25}$ Such was the propensity of this crippled soldier of the army before Troy for indulging in vituperative language that he did not abstain from directing it even against Agamemnon himself. It is related that he ultimately perished at the hand of Achilles, while he was ridiculing the sorrow of that hero for the slain Penthesilia.

The advent of Christianity struck a new note in the attitude toward the crippled and deformed. Even in Isaiah's prophecy ${ }^{26}$ of the coming of the Messianic kingdom, he foretells that "then shall the lame man leap as a hart." Christ, referring to His ministry, ${ }^{27}$ says: "the blind receive their sight, and the lame walk. . . ." It is also related ${ }^{28}$ that " the blind and the lame came to Him in the temple and He healed them."

Many cures of cripples are also attributed to the Apostles. "A certain man lame from his mother's womb" was healed by Peter. ${ }^{29}$ It is related that "immediately his feet and ankle bones received strength." During the ministry of Philip ${ }^{30}$ "many taken with palsies and that were lame, were healed."

"Chapter lxii, paragraph 3.

"Sacred Books of the East, edited by F. Max Müller, Oxford, 1882. Pahlavi Texts, translated by E. W. West.

" Douglas C. McMurtrie, The Primary Education of Crippled Children, New York, I910, pp. 5-6.

" Homer, Iliad, ii, $212 \mathrm{ff}$.

"Isaiah, xoxv, 6.

"Matthew, xi, 5. Also referred to in Luke, vii, 22.

"Mattherw, xxi, 14.

"Acks of the A postles, iii, 2. 
During the mission of the Apostle Paul in Lycaonia, he healed ${ }^{31}$ a cripple described as follows: "And there sat a certain man at Lystra, impotent in his feet, being a cripple from his mother's womb, who never had walked." It is interesting to note that this is the first use in the Scriptures of the generic term, cripple. The Greek word $\mathrm{X} \omega \lambda$ ós is used in the original.

The influence of the Christian attitude had some influence upon the lot of the cripple. I recall one illustrative quotation.32

Also cripples and the sick who remained alive were left to themselves ${ }^{33}$ in Iran as in Armenia and they led a wretched existence. In Armenia it was one of the great services of Christianity that it ameliorated the fate of these unfortunates. ${ }^{34}$

But the new influence was not profound and it did not even permeate the Church in its later development. During the Middle Ages, those burdened with physical deformity were considered as targets for contempt and ridicule, and contumely was continually heaped upon them. ${ }^{35}$

The early Romans had the right to destroy a deformed child provided the child were shown to five neighbors and their assent secured. In the Twelve Tables the decemvirs extended the authority of the father so that he, individually, could destroy or remove crippled children immediately after birth. In many instances they were cast into the street or drowned in the lake into which emptied the sewers of the Eternal City. They were exposed in deserts, in the woods on the banks of the Tiber, in the vegetable market, at a certain pillar in the eleventh district of the city, and, ironically enough, in the very vicinity of the Temple of Mercy. Some few of these unhappy children did not die of exposure or hunger and escaped being torn to pieces by

30 Acts of the A postles, viii, 7 .

"Acts of the A postles, xiv, 8.

"Fr. Spiegel, Eranische Alterthumskunde, Leipzig, 1878. Vol. 3, p. 682.

si. e., abandoned.

" See also Faustus of Byzantium, iv, Chapter 4, and Moses of Khorene, iii, 20.

s Douglas C. McMurtrie, The Primary Education of Crippled Children, New York, I910, pp. 6-7. 
dogs or being eaten by swine. But in spite of their lives being saved, their existence became a wretched and miserable one. They became the slaves of the person who took them up and succored them, and they were intentionally crippled to a greater extent if their deformities when they grew older were not conspicuous enough to render them successful in begging alms for their master's profit. Seneca relates how these unfortunates wandered about exhibiting their mutilated members. He goes on to state that they were intentionally deformed by cutting off their arms, by twisting their shoulders so that they became humpbacked. If the master counts over the daily collection of the beggars and the sum is not,enough, he rebukes the wretches, saying: "You have brought in too little, bring hither the whip; you can weep and lament now. If you had appealed this way to the passer-by you would have had more alms and could have given me more." It may be remarked that this system of peonage in mendicancy is in use even to-day in some communities, notably in Italy and Russia. In the former country many children are mutilated so that they may solicit alms in the streets. In Russia a similar practice is indulged in, the cripples being exhibited particularly at ceremonies and processions.

Among the Romans the trade in slave dwarfs became so extensive and profitable that merchants took children and put them in artificial bandages. ${ }^{36}$ This method, instead of making them well-proportioned dwarfs, made them misshapen and miserable men. This gruesome torture and unnatural art of making dwarfs is also mentioned by Cardanus. ${ }^{37}$ Nascuntur ex parvo patre et matre, fasciis arcte colligantur non affatim nutriuntur, sed teniuntur, which might be translated: born of small parents, they are laced with bandages and fed, not heartily, but sparely. Dwarfs were utilized by the emperor Domitian to engage in sham battles with women. ${ }^{38}$

"Sigaud de la Fond. Wunder der Natur. Part 2, p. 495, also K. F. Flögel, Geschichte der Hofnarren, Leignitz and Leipzig, I789, pp. 507-508.

"Cardanus, De Subtilit. Book XI, p. 460.

"Xiphilinus, In Domitiano. 
Blaise de Vigenere in the notes to his Images et Tableaux de platte peinture de Philostrate Lemnien remarks that when in Rome in 1566 he was invited to a dinner by Cardinal Vitelli, where the table was served "by at least thirty-four dwarfs, almost all hideous and badly deformed."

With the opening of the Middle Ages the chief occupation of the crippled came to be that of court fool or jester. These personages almost universally found a place in the retinues of princes, and of ten in the households of noblemen. ${ }^{39}$

These court fools can be divided under two classifications. In the first would come those creatures who by reason of deformity in body or mind were calculated to excite laughter and ridicule. In the second would be placed those chosen for a certain superficial quickness of wit and power of repartee. It is the first class with which we are especially concerned in our study of the attitude of the community toward the crippled and deformed; and they were to be found, unfortunately, in large numbers. The attire ${ }^{40}$ of these jesters was distinctive, though varying slightly during different periods.

To judge from the prints and illuminations which are the sources of our knowledge on this matter, it seems to have changed considerably from time to time. The head was shaved, the coat was motley, and the breeches tight, with generally one leg different in color from the other. The head was covered with a garment resembling a monk's cowl, which fell over the breast and shoulders, and often bore asses' ears, and was crested with a cockscomb, while bells hung from various parts of the attire. The fool's bauble was a short staff bearing a ridiculous head, to which sometimes was attached an inflated bladder, by means of which sham castigations were affected.

The impressing of cripples into service as court fools continued and the institution was firmly entrenched for many

"K. F. Flögel, Geschichle der Hofnarren, Leipzig, 1789. Nick, Die Hof- und Volksnarren. Stuttgart, 1861, 2 vols. Ebeling, Die Kahlenberger, Geschichte der Hofnarren, Berlin, 1890 .

40 Walter Hepworth, Encyclopadia Britannica, Eleventh Edition, New York, 1910, $x, 614-615$. 
years, despite many tendencies operating to improve the situation. Even a number of decrees passed by the Reichstag during the sixteenth century failed to obviate the practice. Not until the time of the Enlightenment was the final stage reached and the custom abolished.

Even after this time the court fool was still in vogue at the Russian court, Peter the Great having so many jesters of this type that it was necessary to divide them into classes.

When the Spaniards under Fernando Cortez accomplished the conquest of Mexico, court fools and deformed human creatures of all kinds were found at the Court of Montezuma.

It will be observed that the most significant fact developed by the history of the court fool is that during the period covered the victims of human deformity were regarded with ridicule and contempt. In the existence of such an attitude on the part of the general public, a sympathetic or merciful consideration can hardly be conceived.

During the latter part of the Middle Ages cripples came to be regarded superstitiously, this attitude being responsible for a miserable existence for those deviating in any way from the normal. ${ }^{41}$

Ignorant people and scholars alike were influenced by such prejudice, and it is easily seen how cripples and deformed people were regarded as devilish monsters. Several circumstances gave rise to the general superstition. One of the most instrumental was the frequent confession on the rack by unmarried pregnant women that they had been seduced by the devil. This led indirectly to the belief that humpbacked and deformed children might have been of diabolical paternity.

Others regarded the deformed as victims of the wrath of God, and put them to death. King Francis I had burned to death at Avignon a woman who had given birth to a mal-

“T. D. Herholdt, Betrachtungen über den medizinischen Aberglauben und über Missgeburten im Allgemeinen. Appendix to Beschreibung sechs menschlicher Missgeburten, Copenhagen, 1830, pp. 83-162. 
formed child. Often, on the birth of a cripple or of a child with superfluous members, the attack of a hostile army was feared. There is a similar legend of Babylonian origin.

Martin Luther shared the belief, current at his time, in the theory of changelings. At the birth of an undesirable child it was believed that some diabolical mother had stolen away the right child and substituted her own offspring instead. Thus the child was known as a changeling. Cripples, rachitics and cretins were regarded as changelings. The idea was that if such children were maltreated sufficiently their mothers would come again to get them and leave the rightful children in their stead. It is easy to conceive the attitude which such a concept would engender. Luther ${ }^{42}$ also regarded malformed children as mere masses of flesh and considered that killing them was a work well pleasing to God.

Another phase of superstition affected the cripple-the belief that offspring could be harmed by "somebody" or "casting the evil eye" upon the pregnant mother. Parents were inclined to bring the deformity of their child into causal relation to a terrifying pre-natal experience on the part of the mother. In 1673 it is related that a citizen's wife was so frightened at the sight of a one-eyed, lame beggar that when she soon after bore a son, the infant lacked a hand and had a crooked leg. Many other similar instances can be found in literature.

One cripple, Thomas Schweicker (died 1602) of SchwäbischHall, came to be highly regarded ${ }^{43}$ on account of his learning and culture.

The first glimmer of hope for the welfare of the cripple began to appear in the eighteenth century, though the progress in this direction was very slow. The first measures did not in a

${ }^{42}$ Martin Luther. Table-Talk. (Table-talk of the devil and his work-Changelings from the devil-History of a changeling at Dessau-Another history of a changeling.) Theo. Kirchoff. Grundriss einer Geschichte der deutschen Irrenpflege, Berlin, 1890, pp. 65-76.

43 Martin Ulbrich. Th. Schweicker, Eisleben, 1909. 
strict sense mark the beginnings of care for cripples, but they operated to the ultimate advantages of those who, by reason of their infirmity, were cast upon the pity of their fellow-men. The actuating motive of provision in many cases, however, was utilitarian in character. One object was that all cripples might be confined so that they should not annoy the community by their deformed appearance.

Some of the many monasteries which had not been utilized since the time of the Reformation were thrown open and converted into orphan asylums, mad-houses, or penitentiaries. In the establishment of the various institutions the cripple was frequently considered.

Those handicapped by deformity were best provided for at a hospital for wretched and pauper invalids established at Pforgheim ${ }^{44}$ in 1722 by Count Luitgard of Baden. This was later transformed by Count Charles Frederic of Baden into an orphan asylum, but made especial provision for young and old cripples. Kirmsse ${ }^{45}$ quotes parts of the official ordinance on this matter as follows:

Cripples, by Margrave Charles Frederic of Baden. The princely ordinance of May II, 1758, says on this:

"Since we now assume the place of a father to those who are orphaned in our territory or who are otherwise afflicted with grave misfortune, we cannot but desire special experience of our most gracious care to those who, in addition to such afflictions, are at the same time stripped of temporal wealth, and who are, therefore, stricken with double affliction."

"And the third class is composed of those who have such physical defects that they are an especial abomination and disgust to other men whenever they come into their sight. There are utterly misformed cripples and more of the sort."

"Zeilschrift für Krüppelfürsorge, Hamburg and Leipzig, I9II, iv, Io ff.

is Ibid. 


\section{Work.}

"As many of these inmates as can be employed in any work shall be obliged to perform it, yet with reference to distinction of age, sex, and their physical infirmities. Here it is necessary to see in the first place-unless their deformities are slight - that there shall be sought out for them such tasks as may be performed in their rooms.

\section{$\mathrm{X}$. Punishment.}

"Since the other inmates consist of crippled persons, no punishment but a few stripes will be allowed, although they may be chastened either with withdrawal of food or of drink or of both, but in every case after careful consideration of their circumstances.

\section{Duty of Physician.}

"In the same (orphan asylum) are found the most utterly wretched of the entire country, including those sick persons who, in consequence of the cross of God laid upon them, are indeed a horror to other men, but all the more a true object of their pity. And, although, according to the measure of our human understanding they are counted among the incurable, nevertheless God has created many means to make their cross endurable. In their case, therefore, the physician must employ all his best science."

Of those capable of instruction it is noted merely that they should be sent to the school of the orphan asylum "when they could stand it." The cripple department was abolished in I 808 , probably because the room was needed for the insane. ${ }^{46}$

Such provision for cripples, however, gave them asylum only and did nothing in a constructive way to better their condition, but the rise of the science of orthopedics was responsible for the ensuing improvement. It is true that one of the earliest Hippocratic treatises was orthopedic in character, but the attention which had been given to human deformity by the medical profession had, up to the time of which we are speaking, been inconsequential. One of the first to give extensive consideration to such work was Andry of Paris, who pub-

${ }^{46}$ Kelp. Irrenstatistik im Herzogtum Altenburg, Allgemeine Zeitschrift für Psychialrie 1847 , iv, $5^{87} \mathrm{ff}$. 
lished ${ }^{47}$ a two-volume work on orthopedics, illustrated. $\mathrm{He}$ encountered much skepticism. For example, Siebold, in his Chirurgisches Taschenbuch ${ }^{48}$ claimed that the cure of club feet was impossible.

Another advance was made in 1780 when $\mathrm{J}$. A. Venel, who was versed in both mechanics and medicine, ${ }^{49}$ founded an institution for the deformed, at Orbe, Switzerland. Several other surgeons also did valuable work. The most complete books on the subject were by Jörg. ${ }^{50}$

The theories of the various orthopedists were best put into practice in an institution and a large number of these were founded in the first decades of the nineteenth century; as, for example, those located at Paris, London, Leipzig, Lübeck, Berlin, and Vienna. One at Würzburg, established by Dr. Heine, gained especial fame, being the first of its kind in Germany.

The first institution for the deformed in Prussia was established at Berlin in 1823 by Dr. J. G. Blömer. This was designed for pay patients from among the upper classes, but indigent crippled children were also admitted. Between the years I 823 and 1827 he treated no less than I I 79 cases of deformity, of which he claimed to cure 65I. In a passage quoted by Kirmsse ${ }^{51}$ he thus describes the purpose and management of his institution:

An institution such as to be described has long been needed in our monarchy; all the more so because the forms of disability and sickness in question yield but indifferently to treatment outside of such

47 Berlin, 1744.

48 Nuremburg, 1792.

"Description de plusieurs nouveaux moyens méchaniques propres à prévenir, borner, et même corriger dans certains cas, les courbes latérales et la torsion de l'épine du dos. Orbe, 1788.

${ }^{50}$ Ch. G. Jörg. Ueber die Verkrïmmungen des menschlichen Körpers, Leipzig. Die Kunst die Verkrümmungen der Kinder zu verhülen und die entstandenen sicher und leicht $z u$ heben. Leipzig, 1816.

31 Zeitschrift für Krüppelfürsorge, iv, 13 ff. 
a sanitarium. The difficulties in private practice are extensive and the curative methods can seldom be applied to as full an extent as is of ten necessary. Here belongs, among other things, the proper combination and joint application of medical and mechanical treatment, together with the requisite arrangement of suitable occupations for the sick, and the obviation of all factors tending to induce or further increase the physical deformities in question. Upon the persistent and accurate co-ordination of these conditions the possibility of a cure depends; that the elements are usually disparate is responsible for failure in many cases.

Since a large number of the sick who visit the institution are still young, special attention must be devoted to their education. That the invalids may not be impeded in their intellectual development by residence-which is often of long duration-at the institution, my endeavors were naturally directed toward providing for them training adapted to their ages and individual capacities-especially in view of the fact that the intellect is usually very acute and active in sufferers of this type. For still another reason I have been led to devote special attention to the subject of education. In ordinary life a certain obstinacy of character is usually attributed to those who suffer from bodily deformity - unfortunately not always without cause. A very natural cause is the mockery to which these unfortunates are often exposed by their frivolous playmates. They are shunned because their infirmity does not permit them to engage in many games of childhood and youth; they are retsricted to their own company, and, imprisoned in their isolation, become not infrequently malicious. These faults, however, can be more easily removed during youth by continuous moral and intellectual training in an institution; more especially since the similarity of infirmity makes for much in common and demands mutual co-operation. The training is entrusted to a special teacher, who watches in a parental spirit over their morals and instructs them in varied school subjects. Naturally it must be my chief care that such an important position as that of teacher should always be filled by persons of intelligence and integrity.

Not desire of gain; but only the warmest interest in the matter itself, and a deep-seated longing to advance so far as possible the common weal, could lead me to establish an institution for the deformed in which even those of the most slender means can find the 
fountain of their healing and so look forward to as happy a future as possible.

The number of those seeking assistance, however, soon demanded a large institution. This at the same time placed me in a position further to extend my observations. Nevertheless, there were many difficulties to be contended with in connection with such an institution; the exactions demanded of the man who becomes its head are so considerable that long preliminary work and the greatest exertions were required before the institution could enter upon full activity. Considering the end in view, the earthly reward to be hoped for is extremely scanty in return for the manifold and ceaseless efforts expended; the sweetest recompense here is the consciousness of having laid a small gift on the altar of humanity, and of having opened to the poor no less than to the rich the fountain from which they may hope to draw, without expensive outlay, the healing of their infirmities.

Blömer had a workroom for making apparatus, bandages and artificial limbs. It is not known how long his institution lasted.

A similar institute was founded in Stockholm, Sweden, in 1827 by Dr. Ackermann. ${ }^{52}$ There was much difficulty encountered in overcoming public suspicion and distrust. Dr. Günther maintained an institution in Hamburg ${ }^{53}$ during the years 1832-I837. While visiting Hamburg, Dr. Zinc of Vienna became acquainted with this establishment and upon his return to Vienna founded a similar one, ${ }^{54}$ May $\mathbf{I}, \mathbf{I} 838$. This latter much resembled the institute of Blömer at Berlin.

In the meantime, however, there had been founded in Munich in 1832 the first comprehensive institution for the care and education of cripples. The Königliche Bayerische Zentralanstalt für Erziehung und Bildung krüppelhafter Kinder was brought in to being by an eminent philanthropist Johan Nepomuk

" C. J. Eckström. Ars-Berättelse om Svenska Lakäre-Sallskapetts Arbeten, Stockholm, 1829 .

${ }^{6} \mathrm{H}$. Gleiss. Lebenserinnerungen von Elise Averdieck, Hamburg, 1908, pp. 48-50.

${ }^{6}$ Erster Bericht, 1853; Jahresbericht . . . für 1853, Vienna, I854; Correspondenz-Blatt der deulschen Gesellschaft für Psychiatrie, 1854, p. 16; Die angeborener Verrenkungen, Vienna, 1845 , 
and the principles then exemplified have, in general, been followed by most of the modern institutions which have since been established. A description of subsequent work, however, is outside the scope of the present article. In Denmark, ${ }^{b 8}$ England, ${ }^{56}$ Italy, ${ }^{57}$ as well as in Germany ${ }^{58}$ and the United States, ${ }^{59}$ extensive systems of care have been built up, and in almost every civilized country of the world there is made some provision for the welfare of the cripple.

The community has now realized to a very considerable extent its responsibility toward the cripple and the early vicissitudes to which the deformed were subjected are indeed a matter of history.

${ }^{55}$ Douglas C. McMurtrie. The Copenhagen nstitution for Cripples, Boston Medical and Surgical Journal, Boston, 1911, clxv, 794-798.

${ }^{65}$ Douglas C. McMurtrie. Crippled Children in the English Public Schools, New York Medical Journal, New York, 1913, xcvii, 188-199.

${ }^{57}$ Douglas C. McMurtrie. The Care of the Crippled and Rachitic in Italy, Medical Record, New York, 1911, 1xxx, 1218-1222.

"Konrad Biesalski, Umfang und Art des jugendlichen Krüppeltums in Deutschland. Hamburg and Leipzig, 1910. Also the files of the Zeitschrift für Krüppelfürsorge.

${ }^{59}$ Douglas C. McMurtrie. The Care of Crippled Children in the United States. American Journal of Orthopedic Surgery, Philadelphia, 1912, ix, 527-556. 


\title{
A STATISTICAL ESTIMATE RELATIVE TO THE NUM- BER OF CRIPPLES IN THE UNITED STATES
}

\author{
H. Winnett ORR, M. D. \\ Lincoln, Neb.
}

Following the Nebraska epidemic of infantile paralysis in I 909 an extensive investigation was undertaken by correspondence in an effort to learn how many children had been crippled. Through the efforts of Dr. McClanahan and the writer, it was ascertained that there were considerably more than five hundred cripples as a result of this epidemic.

Since the opening of the Nebraska Orthopedic Hospital in 1905, more than one thousand cripples have been treated or observed in connection with this work.

With these facts as a starting point and from further correspondence and inquiry, it is estimated that there are not less than four or five thousand crippled children and adults in Nebraska. Nebraska has a population of a little more than a million. It must be borne in mind that this number of cripples occurs in an agricultural state, relatively free from tuberculosis and in which there are comparatively few of those occupations and industries which contribute to disease and deformity.

It may then fairly be assumed that a proportion of 3,500 cripples to the million of population is a fair estimate. Upon this basis the number of cripples in the various states may be figured out about as follows:

$\begin{array}{lrlr}\text { Alabama, } & 6,414 & \text { District of Columbia, } & 993 \\ \text { Arizona, } & 612 & \text { Florida, } & 2,256 \\ \text { Arkansas, } & 4,722 & \text { Georgia, } & 7,827 \\ \text { California, } & 7,131 & \text { Idaho, } & 975 \\ \text { Colorado, } & 2,397 & \text { Illinois, } & 16,914 \\ \text { Connecticut, } & 3,342 & \text { Indiana, } & 8,100 \\ \text { Delaware, } & 606 & \text { Iowa, } & 6,672\end{array}$


VOL. I.

Kansas,

5,073 Ohio,

4,301

Kentucky,

6,867 Oklahoma,

4,97 I

Louisiana,

4,968 Oregon,

I,9I 3

Maine,

2,223 Pennsylvania,

22,995

Maryland,

3,885 Rhode Island,

I,626

Massachusetts,

4,098 South Carolina,

4,545

Michigan,

Minnesota,

Mississippi,

Missouri,

Montana,

8,430 South Dakota,

I,749

6,225 Tennessee,

6,562

5,391 Texas,

I $\mathrm{I}, 688$

9,879 Utah,

I,019

I,128 Vermont,

I, 065

Nebraska,

Nevada,

New Hampshire,

3,576 Virginia,

6,183

243 Washington,

3,423

I,290 West Virginia,

3,663

7,6I I Wisconsin,

6,999

New Mexico,

I,08 I Wyoming,

435

New York,

North Carolina,

27,339

6,6I8 Total,

259,754 


\section{A COURSE IN BASKETRY AND CANE-SEATING}

Grace F. Hardy

Boston, Mass.

The Industrial School for Crippled and Deformed Children, Boston, Mass., has received many inquiries about the teaching of basketry and cane-seating to primary and grammar pupils. The following course is being used this year and may prove of interest to grade teachers. It is a course in manual training preparatory to work in an industrial department.

\section{Grade I}

Teach elementary principles of weaving by use of the kindergarten mats.

Begin with much drill on "checker pattern" that the children may learn the "over and under" of weaving.

When this is thoroughly understood follow with a simple sequence of lessons in number.

Occasionally use the woven mats in the construction of simple objects as blotter covers, wall pockets, etc.

\section{Grade II}

Take plenty of time in the first of the ycar to teach the children to work well. "Time is nothing when power is growing."

Weaving continued with other materials as worsted, raffia, tape, cord, using A. B. C. looms and simple wooden loom.

Make articles such as

I. Face cloth (darning cotton)

2. Doll's blanket (worsted)

3. Doll's towel, red or blue border

4. Doll's hammock (twine)

5. Book bag

6. Raffia mats. 


\section{Grade III}

Teach names of materials.

Teach names of tools used, care of them and place where they are kept.

Teach braiding of raffia and use it in making mats on reed, open border.

Make short, braided raffia basket on splints, then a taller one.

Raffia mats on reed and splints, using single weave.

Simple splint or palm baskets, using single weave.

\section{Grade IV}

Review names of materials used, their source and manner of preparing them for our use.

More tools are used this year: teach their names, and proper manner of using them.

Teach pairing weave and give many small baskets using this weave.

\section{Grade V}

Teach triple twist and plan to make baskets, now combining use of single weave, pairing and triple twist.

Teach separate base finished with triple twist after stakes are inserted in the base.

Teach cane-seating on small frames using medium cane.

\section{Grade VI}

Plan to spend about half of this school year on basketry and half on cane-seating.

In basketry teach rope twist, Japanese weave and double Japanese weave.

Keep baskets simple in shape but insist on careful jointing, tight weaving, and help children to find flaws in their work and to correct them.

\section{Grade VII}

Combine all the weaves taught in making tasteful baskets. Insist on careful workmanship and help children to see that the 
shape and texture should be suited to the use for which the baskets are intended.

Do some cane-seating and get neatness in joining and finishing off.

\section{Grade VIII}

In this year the children should be able to make many varieties of baskets. They should be trained to be economical in the use of material; to have respect for their tools; to realize that "time is money" and that none should be wasted.

Some work in staining and polishing of baskets should be done. The work in cane-seating should be perfected. 


\section{CONTRIBUTED NOTES}

\section{NEW WORK IN BROOKLYN}

Better hospital facilities for treating crippled children are springing up; well-planned and well-conducted industrial schools for cripples are to be found in several parts of the United States. There is a great number of children living in the tenement houses of the large cities who cannot be accommodated in the hospital wards or in the special schools for crippled children, but who greatly need special care, and, perhaps most of all, careful instruction of the parents in matters of hygiene and of the care of the diseased part. A wisely planned bequest of a public-minded citizen of Brooklyn, N. Y., has made possible this enlarged field of usefulness. By the terms of the will, a definite sum of money was left to the two leading charitable organizations of Brooklyn, with the stipulation that the income only should be used for blind and crippled children of Brooklyn. The method of administration was left to these organizations. The bequest is now in operation. One of the charitable organizations has applied its share of income for crippled to one of the leading hospitals, and there is now conducted there a good open-air roof ward for the tubercular children, under the medical care of an orthopedic surgeon. The other organization has applied their income in two definite directions which are closely related to each other. Establishing a thoroughly well-equipped dispensary in connection with one of the hospitals of Brooklyn, they have placed an orthopedic surgeon in professional charge, and have put three district nurses at his service, whose duties are to assist at the dispensary hours, but more particularly, to follow the cases to their homes, explain the treatment, help ignorant parents in getting the children to and from the hospital, 
and in many ways, co-operating with the surgeon. Thus the education of parents in the possibilities of improvement for their crippled children is greatly facilitated.

Walter Truslow.

\section{CENTRAL STATES ORTHOPEDIC CLUB}

The Central States Orthopedic Club, made up of surgeons engaged in Orthopedics as a specialty in the Middle West, Ohio to Utah, met in November at the Nebraska Orthopedic Hospital. Chicago was especially well represented at the meeting and the men who are doing such splendid work there spoke warmly of the combined hospital and educational work being done in the Nebraska institution.

\section{H. WinNETT ORR.}

\section{THE NETV ENGLAND PEABODY HOME}

The New England Peabody Home for Crippled Children, at Hyde Park, Mass., started in 1894 with but a few cases, now has from thirty to forty crippled children in its care.

Many of these are cases of surgical tuberculosis, the others are infantile paralytics.

The plant comprises a hospital department with an orthopedic nurse in charge. There are shacks and sleeping porches, and facilities for trying the sun cure so successful in Switzerland. There is a school also, and classes in cooking, sewing, woodworking, chair-caning, and basketry are carried on at different seasons during the year.

Many of the children are able to assist in the housework and it is surprising how much they can accomplish, and what pride they take in doing even the humblest tasks.

No child of unsound mind, or over twelve years of age is admitted to this Home and none are taken for less than two years, as little in the way of improvement can be done for him in less time than that. 
If both parents are living and can afford it, a small sum is charged for board, but no deserving case is ever turned away and there is a long waiting list.

If at the end of two years the child can attend public school or can be cared for at home, he is discharged. In the past eight or ten years a good many children have been returned to their families or placed in other homes. With nearly all of these we are in close touch, and they are especially interesting to us, showing as they do what they have acquired during their stay here. One boy has started in to mend shoes. Another lives with a widowed mother who goes out to work by the day. The boy is in high school, and now is planning to go into poultry raising as soon as he has finished his high school course. From the Sloyd lessons he had with us he can do much in the way of small jobs of carpentry and is a great help to his mother.

A girl with us for eight years now keeps house for her mother, a mill operative. One has gone into a small factory, another is in a telephone office, while still another, who has not left us, is taking lessons in primary grade work to help with the younger children another year. She has marvelous influence over the little ones and although confined to her chair they never think of taking advantage of her but always yield her obedience. With some she uses kindergarten methods, having taken lessons from a visiting teacher, while the older children study reading and language with her. During the past year our oldest girl has been able to assist in the night work, proving herself quite capable of the responsibility.

To persons outside of, yet interested in, an institution like ours, it is possible that its progress is more apparent than to those actually working within its four walls. One duty following another so closely; so much apparently completed can be improved upon or added to, while the constant coming and going of the children is so absorbing that we can only hope for without realizing much advancement. 
The past two years have seen the fence completed enclosing now our entire property. A rustic gate with swinging sign opens on Gordon Avenue, while large double gates have been placed at the entrance to the driveway. A new play house has been built not far from the main house and connected with it by a cemented walk and pergola over which vines have already begun to climb. The play house is spacious enough to take in all of the children and the different groups can play there without interference. The swings and incline furnish plenty of amusement in all kinds of weather, so the house is a great factor in caring for the children out of school hours. The smooth cemented walk admits of easy passage to and fro to the children of slow locomotion dependent on crutches and wheelchairs, and they are enabled to get out into sun and air much more frequently and easily than when the ground was in its ungraded state. A pergola now completes what is known as the children's porch, adding greatly to the appearance of the house as we approach from the street. Vines already covering a large portion of it, a flag flying from a corner, and children at play or passing in and out make a vivid picture of life and activity in our very homelike housc.

May I tell you a little incident that occurred the other day as I sat in the office planning some work for the day? An old man in search of employment strayed in to the main hall just as our children were gathered in groups waiting for the bell to call them into the schoolroom. A girl, holding on to her crutches with very slender hands heard him exclaim, "How awful! Something's the matter with every one of 'em." The girl, meeting his look of commiseration replied: "We don't think it's awful. We have lovely times here." Then appealing to her teacher, she added, "It's not so bad to be a cripple, is it?"

Clara M. Thurston. 


\section{NEW BUILDING FOR NEBRASKA HOSPITAL}

The Board of Commissioners of State Institutions has just authorized the expenditure of funds on hand for the construction of a new fire-proof building for the Nebraska Orthopedic Hospital. This is to be an administration and surgical building of entirely fire-proof construction to cost about $\$ 45,000$. It will be II 2 x 40 feet and will contain offices, library, the operating room and its related departments, and wards for about fifty patients.

This will give the institution a capacity of one hundred and fifty with adequate space for housing fifty employees, schoolrooms, recreation room, etc. A new laundry, assembly hall and an outdoor sleeping porch for nurses, all of modern construction, have just been completed.

\section{H. WinnetT ORR.}

\section{MUTUAL ALLIANCE IN CLEVELAND}

In Cleveland, Ohio, there exists a triangular alliance, for the benefit of crippled children, between Rainbow Cottage, Lakeside Hospital, and the Cripple School Visiting Nurse. Rainbow Cottage also has co-operative relations with the Benjamin Rose Foundation. The situation is described in the I913 Social Year-Book of Cleveland as follows:

Cases are admitted directly from the wards and dispensary of Lakeside Hospital, and every case reported through any agency is investigated by the Rainbow Cottage and Cripple School Visiting Nurse, and taken to Lakeside Dispensary for examination by the same physicians and surgeons who afterward care for the patients at Rainbow Cottage. These patients vary in age from the baby taken at one month old to a child of fifteen years of age. Though by no means limited to crippled children, the greater part of the cases are of this handicapped class, and many children of six, eight, ten or twelve years of age have taken their first step at Rainbow Cottage.

The aim of this Institution is to be a well-equipped plant, conducted on the best business principles for converting into wage earners children who, without this care, would be a charge upon the State for life. 
Working along the lines laid down by the Benjamin Rose Foundation, for three years Rainbow Cottage has been one of the institutions selected by this foundation to carry on its work. Its generous support in the last year has enabled the Cottage to give 5,79I day's of care to crippled children, many of whomre main longer than six months specified by the founder of this trust.

The quiet, fresh air, good food and medical care have been especially efficacious in chorea and rheumatic heart cases, which cannot receive the absolutely necessary care in crowded and unsanitary homes.

The work for many years has been limited, not by the needs of the convalescent children of Cleveland, but by the limits of the accommodations of the Rainbow plant, and a new building is under construction, which will materially increase the number of patients that can be received, and will necessitate a much larger income.

The demand by doctors, nurses, and philanthropic workers, for more beds at Rainbow Cottage has been so imperative and the response to its plea for a new building has been so generous, that the Trustees have assumed these larger responsibilities.

The work at Rainbow Cottage during the past year may be represented thus: hospital days treatment given during the year, 13,859; days of surgical treatment, 8,686 ; days of medical treatment, 5, I 84; cost per capita per diem, $\$ \mathrm{I} .45$.

\section{Marion A. Parsons.}

\section{A SYSTEM OF INDUSTRIAL EDUCATION}

The Free Industrial School for Crippled Children was incorporated by an act of legislature on May 27, I903. It maintains a city institution at 47 I West 57 th Street, and a country Branch, the Lulu Thorley Lyons Home, at Claverack, N. Y. The object is to provide crippled children of the poor with food, clothing, schooling, manual training, medical and surgical treatment and appliances, and to train them for lives of usefulness and self-support. There is no question of creed, race or color. Any child that is crippled and in need of attention receives ready admission into the School and Home.

The work is continued through the entire year-eight months 
at the city school under competent teachers in kindergarten, primary and grammar classes; the girls have cooking lessons and are taught dressmaking and fine sewing; the boys useful handicraft work. The summer months the children spend at the country home, where the life is ideal, the children spending most of the day out of doors, sleeping in tents on pleasant nights. The society has no city or state aid and no endowment, depending for support on voluntary contributions, entertainments and membership dues. The work is non-sectarian and there are no paid officials.

A certain percentage on the sale of their work is paid to the children. This admirable system does away with the possibility of accustoming the children to the thought of charity, of inculcating in them that soul-destroying idea, that misfortune of itself deserves support. The world may ask as much of these children as of any others, they are being prepared to meet all demands with courage and self-respect.

Lilian Gilbert Fish.

TRADE CLASSES OF THE BREARLEY LEAGUE

In 1908, being urged by the Children's Aid Society of New York City to undertake the management and support of the classes for crippled children in their Rhinelander School, $35^{\circ}$ East 88th Street, the Brearley League decided to enter this comparatively new field of charitable rork. During its first experimental year the League had charge of manual training classes of two grades for boys, and classes in sewing of two grades for girls, instructing them for two hours after their regular school work was finished.

Having gained experience in the management and the adapting of the work to meet the individual handicap of the scholars, two trade classes were added the following year for pupils over fourteen years of age, with the aim of helping them to become wage earners and to obtain regular positions-a jewelry class for boys and an embroidery class for girls. 
The jewelry class was started under adverse criticism and discouraging predictions, because other organized help for crippled boys had proved impracticable. We are now closing our fourth year and feel that our faith in this venture has been justified. Eighty per cent. of the pupils placed with manufacturing jewelers have shown such proficiency that the school may feel satisfied with their instruction. A skilled teacher instructs this class and the boys work six hours each day. A far larger result must be gained than the mere mechanical teaching of a trade, for our boys come to us greatly handicapped in character, and one of our most difficult problems is to instil regular habits, give a more healthy viewpoint, foster ambition which has generally been discouraged, and thus make the pupil learn that for him, as for his more fortunate brother, a useful life is within his possibilities.

The embroidery class, from nine to three o'clock, also under competent instruction, marks household linen, and does Swedish weaving, and cross-stich designs. This is a branch of work for which there will always be a steady demand, and it is of great adaptability to the misfortunes of the workers. The class has been filling many orders most creditably, and the girls are paid a regular wage, being also paid for piece work done at home.

Manual training classes in wood and brass work for the younger boys, and graded sewing classes for the girls are being carried on in order that they may be more efficient on entering the trade classes.

The League employs a trained nurse to oversee the children's physical welfare, give treatments at the school, and visit their homes to consult and advise about their care.

Owing to the generous services of Dr. Brainerd H. Whitbeck, and Dr. Francis J. Sloane, the children are under expert surgical and medical care. Adjustments of plaster casts are made at the school, and when braces have been ordered the League has supplied them. One afternoon of each week the younger children are entertained by the League members, and on holidays ice cream and cake are provided. LOUISE BALDWIN. 


\section{EDITORIAL NOTES}

PUBLIC SCHOOL ClasSES IN CHICAGo

Special classes for crippled children have been maintained as an integral part of the Chicago public school system for several years. These classes are located at the Fallon and Spalding Schools. The average daily membership ${ }^{1}$ has been as follows:

Schools for Crippled Children-Average Daily Membership

\begin{tabular}{|c|c|c|c|}
\hline YEAR & MEMBERSHIP & YEAR & MEMBERSHIP \\
\hline $1903-1904$ & 103.6 & $1908-1909$ & I $35 . I$ \\
\hline $1904-1905$ & 125.2 & I909-1910 & $145 \cdot 7$ \\
\hline $1905-1906$ & 122.8 & $1910-1911$ & 134.4 \\
\hline 1906-I907 & $97 \cdot 3$ & I9II-I9I2 & 130.5 \\
\hline $1907-1908$ & II 9.6 & $1912-1913$ & 143.7 \\
\hline
\end{tabular}

The cost per pupil of maintaing the special schools for crippled children, based on average membership, and including teachers' salaries, janitor service, supplies, and all other incidental expenses, was $^{2}$ as follows:

$$
\begin{array}{rr}
\text { I908-I909 } & \$ 164.66 \\
\text { I909-19I0 } & 178.02 \\
\text { I9IO-I9II } & \text { I80. } 89 \\
\text { I9II-I9I2 } & 213.7 \text { I } \\
\text { I9I2-I9I3 } & 163.86
\end{array}
$$

${ }^{1}$ Fifty-ninth annual report of the Board of Education, City of Chicago: Report of the Superintendent of Schools, for the year ending June 30, 1913. Preprint, Chicago, 1913, p. 263.

2Ibid., p. 265. 
The total expenditures charged against the schools for crippled children were ${ }^{3}$ as follows:

$\begin{array}{lr}\text { I908-I909 } & \$ 22,245 \cdot 57 \\ \text { I909-I9I0 } & 25,937.69 \\ \text { I9I0-I9I I } & 24,330.79 \\ \text { I9II-I9I2 } & 27,887.91 \\ \text { I9I2-I9I3 } & 23,547.06\end{array}$

The salary of teachers for crippled children is $\$ \mathrm{I}, 300$ per annum. ${ }^{4}$ Six teachers were receiving this in June, 19I3.

The cost of maintaining the classes during the past year was ${ }^{5}$ distributed as follows:

Average daily membership

For teachers' salaries, $\$ 10,119.00$

For fuel, light, janitors, supplies and other expenses, $13,428.06$

Total cost, $\$ 23.547 .06$

The per capita cost of \$163.86 during I9I2-19I3 was itemized ${ }^{6}$ as follows: salaries of teachers, $\$ 70.42$; for janitors, fuel, supplies, repairs and all other operating expenses, $\$ 93.44$.

With the average membership of 143.7 the total enrollment during the year was 198 , of these 119 were boys and 79 girls. The average daily attendance ${ }^{8}$ was 134.0 giving an attendance percentage of 93.9 .

Special vacation schools are maintained by the Board of Education. During the summer recess" "twenty-one regular schools were opened and classes for deaf, crippled, and anæmic children were included in the general plan." The crippled children "were provided with the usual transportation, and

'Ibid., p. 268.

Ibid., p. 260.

Ibid., p. 252.

Ibid., p. 251 .

Ibid., pp. 102-103. 
the class-room features were varied to harmonize with the spirit of the vacation schools." Sessions were held on four days of the week only. The results were considered highly satisfactory.

In the Department of Child Study and Educational Research of the Chicago public school system, 68 crippled children were studied during the past year. "From the point of view of the examination of crippled children of school age, the two main points which emerge in every examination are the determination of the crippled status of the child, need of free transportation to and from school, and his education under adaptable conditions. Of the total number of 68 children of this class investigated, twelve were found to be non-educable, and about as many more were reported from homes whose history and status gave such palpable evidences of physical and mental weaknesses that, under advisement, the demands of parents were satisfied by having them remain under home care." 10

THE FIRST STATE INSTITUTION FOR CRIPPLES

The Minnesota State Hospital and School for Indigent Crippled and Deformed Children, at Phalen Park, St. Paul, was the first institution for crippled children in the world to be started wholly by legislative initiative and supported by public funds. It will not be possible here to give an extended description of this splendid institution or its work, as that will be reserved for detailed treatment in a later issue, but a quotation 11 may be made from a recent. report, which will give some idea of the extent and character of the work.

$75^{8}$ children have been admitted to the Minnesota State Hospitals for Indigent Crippled and Deformed Children. 385 have been absolutely cured of all disease and deformity. 194 have been discharged improved. These children still have some deformity remaining, but they have been cured of their disease and suffering, are no longer in

10Ibid., pp. 120-121. Report of Daniel P. MacMillan.

"Report and History of the Minnesota State Hospitaland School for Indigent Crippled and Deformed Children to Sepiember 1, 1912. St. Paul, 1912. Report of the Surgeonin-Chief, Arthur J. Gillette, p. 6. 
need of treatment, will be able to care for themselves through life, and will not be a burden to the State. There have been 34 children discharged as unimproved. This is due in many cases to the fact that the parents refused to leave the children with us as long as was necessary. There have been 62 deaths, which is a very small percentage of deaths among children, especially when one considers that more than three-fourths of the children admitted were suffering from deformities due to disease. In short, a deformity due to an injury or present at birth is rather rare.

Not only have these children been relieved of their suffering and deformities, but they have been able to continue their education, and many of them have been taught industrial work as well. None of them have lost anything educationally by being in the Hospital, for the regular curriculum taught in the public schools is followed, and in many instances the children have received instruction while in bed, before they were able to go to the school room in the Hospital.

It is quite interesting to note, and inspiring too, to find that the school work is usually of great benefit to the children in a medical way, as it assists in whiling away many hours in bed which would be very tedious if they did not have something to do to keep them from brooding over their physical conditon. It is not unusual, when the physicians and surgeons are making their rounds to have the children beg to be allowed to begin school work, and we do so just as soon as possible in all cases, for the children are much better off both mentally and physically.

\section{A PHILADELPHIA REPORT}

The thirty-first report of The Home of the Merciful Saviour, Philadelphia, Pa., has just been issued. The main plant is located at 4400 Baltimore Avenue, Philadelphia, while a summer home is maintained at Avon-by-the-Sea, N. J. According to the report "the Home takes crippled, homeless, destitute children from any country, State or city without board or entrance fee. Many of its inmates are those discharged from hospitals. The children receive the best surgical and medical treatment. The training is according to the trend of the child's mind, and many improve in health to such a degree that they go out self- 
supporting men and women. It is the prolonged stay in the Home which make this possible. The religious life is carefully nourished, and those in charge give love and personal care to the little ones."

A report of the present occupations of former pupils is given as follows:

F. spent two years in Children's Hospital and is now practising her profession ; H., organist in large city church; $C$. and $H$., wireless operators; W. G., telegrapher; I., lawyer; M. A., literary work; A. and N., librarians; J., jeweler; W. M., shoe factory; M. R., seamstress; E. L., seamstress; M. F., cutter of clothes; L. S., seamstress; B. M., seamstress, M. H., sexton of church; G. B., salesman; J. B., and E. K., cigar rollers; W. P., drug store.

It would be interesting to have the data in more detail, as for instances, age, sex, degree and type of deformity, working conditions and wages. The financial report shows receipts and expenditures of approximately forty-six thousand dollars. There is no statement in the report of the number of children to whom care is given. The institution was the first residen home for crippled children founded in the United States.

\section{INSTITUTION FOR NEGRO CRIPPLED CHILREDN}

The House of St. Michael and All Angels, Philadelphia, Pa., is the only institution in the United States exclusively for crippled children of the negro race. This does not mean that the colored cripples are not received by other institutions, but this is the only institution specifically designed for their needs. It accommodates about thirty children, the annual expense amounting to approximately $\$ 5,000$. At present about one tenth of this sum is paid by the parents and friends of the children toward their board, two fifths comes from interest on investments and the rest is from annual subscriptions and donations. The Sisters of S. Margaret who are in charge of the work receive no salary whatever. 
HOSPITAL SOCIAL SERVICE FOR CRIPPLES

The Social Service Department of the St. Louis Children's Hospital presided over by Miss Julia Stimson, is taking an active interest in the welfare of crippled children. One feature of the work, concerned with the supply of braces prescribed by the physicians, is decribed ${ }^{12}$ in a recent report.

A large and important department work has grown out of the need for financial investigation in the matter of payment for braces and other apparatus. The doctors often found they were handicapped in their treatment of children by the inability of parents to supply what the doctors considered necessary for the child, and often by the refusal of parents to bring their children back to the clinic because they could not pay for necessary apparatus. It came about then, that whenever a brace was found necessary, the matter was referred to the Social Service Department for financial investigation. At the present time all bills for orthopedic apparatus go through the Department. Relatives of the children are sent to confer with the head of the Department as to the matter of payment. Frequently all that is required is the permission to pay on the installment plan, a little at a time, but in a good many instances it is necessary to call upon various charitable organizations of the city to assist in the payment.

In every instance in which a brace was ordered for a patient, one has been secured, making $100 \%$ efficiency in this respect.

\begin{tabular}{|c|c|c|c|}
\hline & ORDERS & PAYMENTS & $\begin{array}{c}\text { AMOUNT OF } \\
\text { BILLS }\end{array}$ \\
\hline Closed Accounts, & 125 & 84 & $\$ 800.20$ \\
\hline Outstanding Accounts, & 53 & 40 & 458.95 \\
\hline Total, & 178 & I 24 & $\$ 1,259.15$ \\
\hline
\end{tabular}

"Social Service Department of the St. Louis Children's Hospital and the Washington University Hospital. Second Annual Report, St. Louis, 1913. Pp. 18-19. 


\section{Brace Payments}

\section{Patients' Families, Children's Hospital, Outside Agencies,}

Balance due,

Total account,
OUTSTANDING

$\$ 229.05$

I0.00

38.40

$\$ 277 \cdot 45$

Number of patients assisted (in whole or in part) 47 or $37 \%$

Money paid by outside agencies, $\$ 301.60$ or $24 \%$

Another feature of the work of this department will be described in detail in an early issue of this JourNaL.

\section{DRIVING FUND FOR CRIPPLED CHILDREN}

The Crippled Children's Driving Fund of New York City gives some data regarding its work in a recent report. ${ }^{13}$ During the active driving months, from April to October inclusive, 721 driving parties were given, representing i 1,689 individual drives. Some of the children, of course, were taken on several occasions. The report continues:

The crippled child is called for at its home or at an institution, and under the supervision of responsible women is given a two hours' drive in the open air, in our own stages built specially for this work. The drives are usually conducted through Central Park, and a stop is made at the Swedish Cottage therein, where the children are given refreshments of milk and crackers, and are permitted to play on the lawns for a brief period. They are then brought back to their homes or institutions, much the happier and healthier for these hours of sunshine, good air and diversion.

It has been definitely established that the physical condition of the

"Crippled Children's Driving Fund. Report for 1913. New York, 1913. pp. 5-6. 
crippled child which has had the benefit of our drives, has thereby been vastly ameliorated.

Our files, containing carefully kept records of crippled children's individual cases, now comprise 4,300 names.

\section{THE MAGAZINE OF AN ORGANIZATION}

Several institutions for crippled children throughout the country have magazines published in the interest of their work. One of the most flourishing of these publications is the Van Leuven Browne Magazine issued by the Van Leuven Browne Hospital School, Detroit, Mich. The magazine is now in its third volume. It contains current news and items regarding the local work, written in an intimate vein. The material which is perhaps of greatest interest to the outsider, however, comprises sketches of the life and work of crippled and handicapped persons throughout the country which are collected by the editor, Miss Browne.

\section{OTHER INSTITUTION ORGANS}

Among other publications of a similar nature may be mentioned the Crippled Children's Messenger issued by the Free Industrial School for Crippled Children, New York City, and now in its fif th volume; the Journal of the Home of the Merciful Saviour, Philadelphia, Pa., now in its twenty-eighth volume; the Brooklyn Cripple News, published in the interests of the House of St. Giles the Cripple, Garden City, L. I.; the Crippled Children's Herald of the Industrial Home for Crippled Children, Buffalo, N. Y.; and Sweet Charity issued by the Good Shepherd Home, Allentown, $\mathrm{Pa}$.

\section{AN ANNIVERSARY CELEBRATION}

The Good Shepherd Home of Allentown, Pa., celebrated its fifth anniversary on September 1, I9I3, and issued a program ${ }^{14}$ of the occasion. The most important feature of the work of this Lutheran institution is the maintenance of a home for crippled and blind orphan children.

"The Fifth Anniversary of the Good Shepherd Home. Allentown, Pa. 1913. 


\section{PROVISION AT ATLANTIC CITY}

The Children's Seashore House for Invalid Children, Atlantic City, N. J., an institution, originally for summer use only, has been open during the past four seasons throughout the year. During this time there have been 13,946 admissions. Among these there have been 225 cases of hip joint disease, 214 cases of Pott's disease, 79 cases of osteomyelitis, I64 cases of other bone diseases and convalescents from pneumonia, typhoid fever, empyema and other acute diseases. These cases were sent to the institution from 32 hospitals in Philadelphia and elsewhere. The improvement in all the children has been marked. This has been the result of the out-of-door life, the sea air, the abundance of nourishing food and the happy life provided. The children, including the bedridden ones, live all day in the open air and sunshine and pass their nights in wards through which the sea breezes blow without obstruction throughout the year except on the few nights on which the rain or snow must be kept out. Up to the present time 72 beds have been kept in constant use for the winter work, and over four hundred are available in summer. 


\title{
AMERICAN JOURNAL OF CARE FOR CRIPPLES
}

\author{
Published By the \\ Jfereration of Associations for Cripples
}

\author{
EDITED BY \\ Douglas C. McMurtrie
}

EDITORIAL BOARD

Russel.l H. Hibas, M. D. Robert W. Lovett, M. D.

Arthur J. Gillette, M. D. H. Winnett OrR, M. D.

Charles H. Jaeger, M. D. John Ridlon, M. D.

Konrad Biesalski, M. D. Robert Jones, F. R. C. S.

PUBLICATION COMMITTEE

FOR THE FEDERATION

Miss Adelaide B. Baylis Mrs. Helen K. Travers

Mrs. Henry B. Barnes Mrs. George F. Shrady

Volume I Number 2

NEW YOR K

I 914 


\title{
AMERICAN JOURNAL OF CARE FOR CRIPPLES
}

\author{
VOLume I Number 2 \\ NEW YoRK, JUNE, 1914
}

\section{CONTENTS}

Trade training for adult cripples. Charles H. Jaeger. . . .

A new field of work for crippled children. MABEL IRving

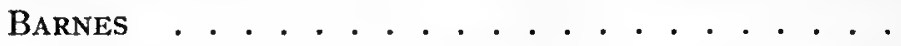

A fifteenth century painter of cripples. Douglas C. MCMurTRIE . . . . . . . . . . . . 76

Country homes for cripples in the vicinity of New York . . . 78

The mentally defective cripple. Douglas C. McMurtrie . 82

Contributed Notes . . . . . . . . . . . . . . . . . 88

Public school work for cripples in Baltimore, Edwin HEBDEN,-Work of the Driving Fund, Bertha Smith.-Public School classes in Chicago, E. C. Rosseter.-Work of the Brearley League, Louise BaldwiN.-Anniversary celebration, JoHN H. RAKER.

Editorial Notes . . . . . . . . . . . . . . .

Federation of Associations for Cripples.-Semi-annual meeting of the Federation.-Welfare Commission for Cripples.-Constitution.-A change of name.-An institution in the Far West.- Stenography at East Side Free School.-American Orthopedic Association.-American Open Air School Association.-Year's work of St. Charles Hospital.- Summer cottages for ctippled children.-Editorial comment on this Journal.- Move to a country home.-Aid for the victims of work accidents.-A French society for the crippled.-Home for incurables in Buffalo.-State provision for the crippled.-A publicity booklet.-Enlargement of the Munich institution.-Public school class in Philadelphia.-Establishment of the Philadelphia class.

Bibliographical Notes . . . . . . . . . . . . 109

Published quarterly by the Federation of Associations for Cripples at 3505 Broadway, New York City. Subscription price, $\$ 3.00$ a yearly volume.

Application for entry as second-class matter at the post office at New York, N. Y., pending. 



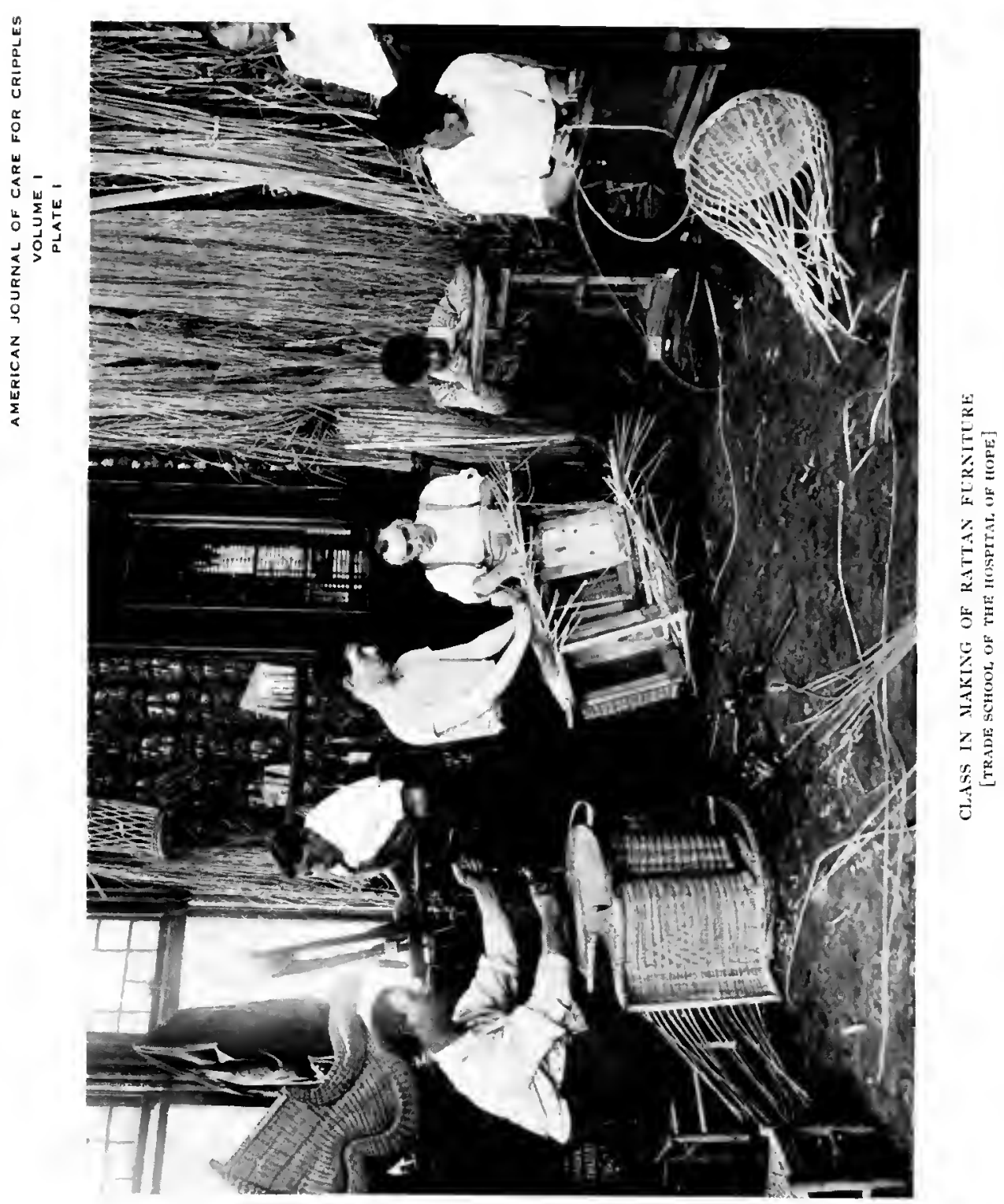




\title{
TRADE TRAINING FOR ADULT CRIPPLES
}

\author{
Charles H. Jaeger, M. D. \\ New York
}

In considering the problem of trade training for cripples, we must first classify them in groups according to the nature of their disability and then state the problem as it relates to each group.

1. The congenital cripples:-Those born with some malformation not amenable to medical or surgical treatment, who must go through life with a physical handicap.

2. The cripples from disease:- - of which there are two kinds, (a) those who are suffering from some constitutional disease like tuberculosis which makes the patient, in addition to his diseased condition, weak and incapable, and $(b)$, those who are left crippled by some disease like infantile paralysis or hemiplegia which leaves them more or less badly disabled but which has no influence on their physical well-being.

3. The cripples from accident (the various amputations). Again we have two classes, those crippled in childhood, thus subjected to all the unfavorable influences surrounding the diseased crippled child, and the second class, those crippled by accident in later life.

As will readily be seen, the different groups are so dissimilar, that it would be impossible to give any one remedy which would help all classes.

It is the last class which is a very important class, firstly, because of the large number of people maimed in this country in the pursuit of their daily occupations, and secondly, because we have here a group of people who have had a normal youth, who have acquired no mental kinks and who have been 
trained to some occupation or trade. This is, to my mind, the ideal class to work with, the most important class to work with. These cripples have passed through the vicissitudes of childhood, have been engaged in gainful occupations, have possibly assumed family responsibilities, in other words, have proven their industrial worth.

To save a man of this group from pauperism is, therefore, not only more satisfactory, but is of greater economic importance. Assistance to persons of this type is imperative, as they are the ones psychically most affected by their accident. They easily become depressed, and their long convalescence induces habits of idleness.

Well-intentioned but ill-advised friends and relations coddle the patient. He is cared for and supported until he has lost his ambition to work. In his idle hours he seeks solace and companionship in the saloon. This environment still further aids in the moral decline. It is an easy step to beg for the money thus needed, and when he once finds out how profitable this is, he loses his desire for work.

The cripple who can get about easily, for whom the problem of going to and returning from work does not exist and whose appearance is not objectionable, can easily take care of himself. We have, however, a large class, comprising the victims of severe infantile paralysis who are confined to a wheel chair, and the spastic paraplegiacs. These manifestly cannot hope for employment in large shops. They belong to the 'shut-ins' who must work at home and seek their market outside at some exchange or among private customers.

The shut-in cripple needs guidance particularly in the choice of articles he puts on the market as well as in discrimination as to design. By offering well-designed articles of intrinsic value, the purchasing public, which has hitherto been confined to a few wealthy individuals impelled to buy from charitable motives, will be augmented by the public at large.

If the public realized with what difficulties the cripple is 
beset it would readily extend its co-operation to minimize the detrimental influences. The manifold incapabilities, with their attendant limitations, result in unusual brain processes. We have those who are precocious, having been reared among adults and deprived of the companionship of children of their own age. We have those who have been unduly spoiled because of their affliction supplemented by an appealing child's countenance. We have those whose sauciness was mistaken for cuteness and who have developed in to adults of rare impudence in speech and an aggressive attitude towards others. Most cripples are sensitive to an abnormal degree, rendering it difficult to deal with them as they take offense where none is intended. For this reason they will give up a position, leaving behind them an impression of disloyalty and ingratitude. As they have rarely had mental training-especially with the view of becoming self-supporting-their schooling has been at best haphazard, so that they have acquired neither concentration nor discipline. For this reason many cripples after having become proficient in a trade take up the desultory life of begging and tramping in preference to following their regular occupation. There is also a large class of undeveloped cripples and I cannot emphasize too strongly that work with this type offers the best opportunity for successful results. These poor, neglected children, not spoiled by over-indulgence or schooled in depravity, have proven that, with a little care and effort expended along right lines, the problem of the cripple can be solved.

Parents are apt to sympathize unduly with the affliction, underestimate the mental powers of their crippled children, and consequently neglect to give them the necessary preparation for a useful life. In fact, indulgence of the elders during the childhood of the cripple has developed the prevalent attitude that the world owes them a living. Not having been inspired with hope or ideals they readily take to mendicancy and criminality. 
This condition is further induced by the lack of facilities, there being in the great city of New York only the trade classes of the Brearley League, the Free Industrial School for Crippled Children, and the East Side Free School.

The Trade School of the Hospital of Hope for Crippled and Injured Men at 159th Street and Mott Avenue is the only one of its kind in New York City which offers opportunity for adults to learn trades suited to masculine inclinations and abilities. There is taught reed and willow furniture work, basket making, chair caning, rush seating, cabinet making and repair work, copper and silver smithing, mechanical drawing and show-card writing, engraving in its various branches (including brass and steel die work, wood cuts, and jewelry engraving), mosaic art glass work, and cobbling.

After the training is received the question as to the possibility of obtaining employment must arise.

Many manufacturers will not employ badly crippled workers. They not only object to their appearance but they are afraid that they are not able to do a full day's work, and they do not wish to mix sentiment with business. There is also a new factor in this connection which must be considered.

Compulsory industrial insurance is being introduced in various states. This compels each manufacturer to provide insurance against accidents to his employees. Accidents are often unavoidable and occur with only too great frequency among normal able-bodied men. It is presumed that a crippled or disabled man cannot so easily guard himself against injury and for this reason accident insurance companies will not issue a policy to a factory in which this class of men is employed.

To make future employment reasonably certain it is therefore absolutely necessary to train the men so well that they become highly skilled. Their service will then be sought after in spite of their affliction.

It is also important to select trades which are not overmanned with good workers. In reading the want advertise- 
AMERICAN JOURNAL OF CARE FOR CRIPPLES

VOLUME I

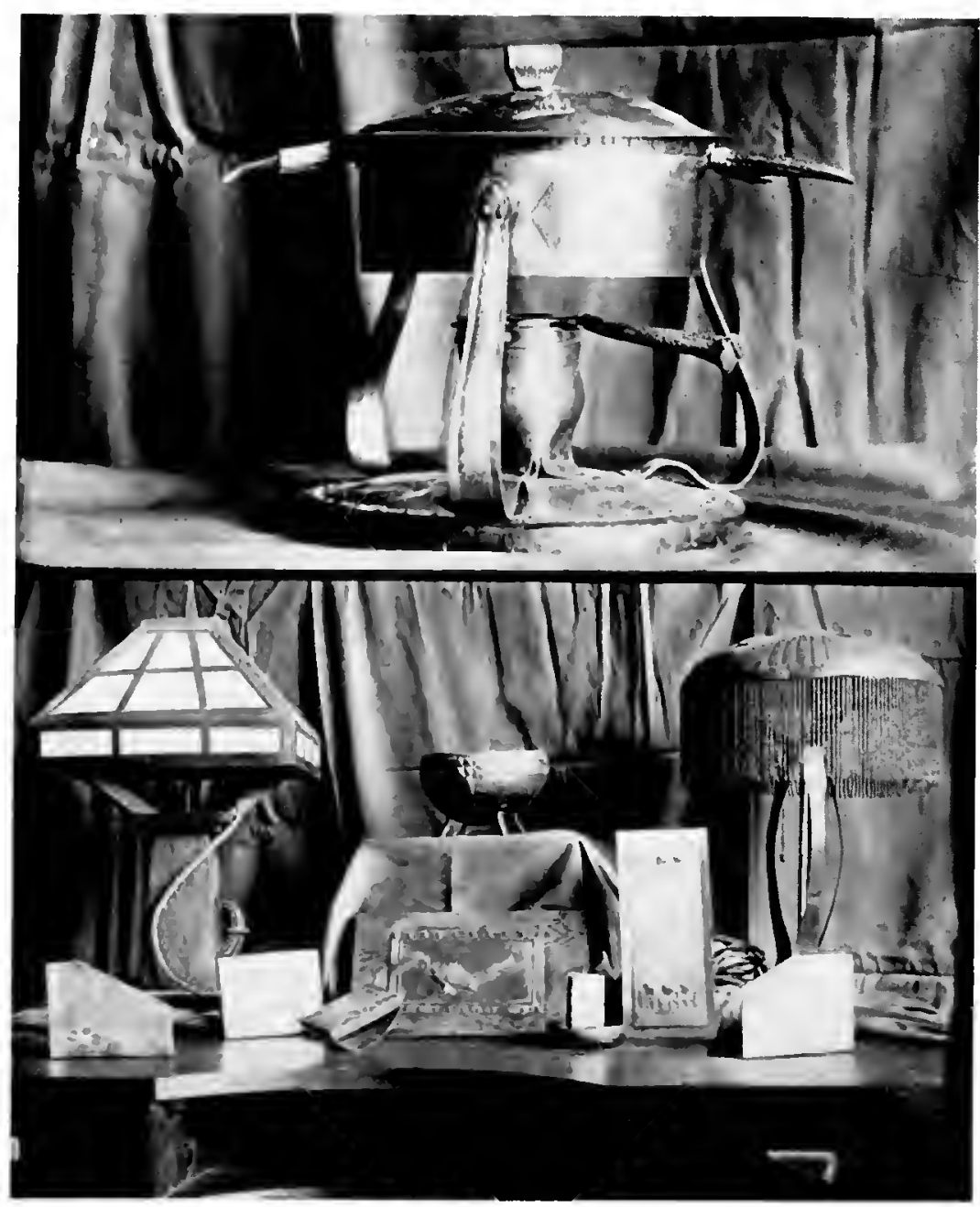

ARTICLFS MADE BY CRIPPLED ADCLTS

[TRADE: SCHOOL, OP THE HOSPITAL, OF HOPE] 
ments one comes across a repetition of demands for certain classes of workers. As the labor unions have the policy of restricting apprentices, the cripple has the advantage of being able to step into vacant positions.

An estimate made by Dr. H. W. Orr would show that there are 3,500 cripples to the million inhabitants. It has been estimated that there are about 30,000 in the City of New York. Trustworthy statistics show that there are 500,000 people annually injured and maimed in the United States in the mine work, transportation, and industries.

In this country we have not yet provided adequately for the welfare of these people. The cripple is too frequently dependent on his family or on charitable institutions.

It has been the achievement of other countries to give the example of how best to deal with the problem. Cripples are taught useful trades and large orders are placed with the institutions that provide for them. In England governmental orders are executed in custom tailoring for the army and navy. Institutions in Germany buy their supplies whenever possible from other institutions, thus carrying out the co-operative idea. In Russia a trade class connected with a St. Petersburg hospital makes orthopedic braces. This serves the double purpose of teaching a useful trade and makes it possible to provide braces at a minimum cost for cripples of the poorer or indigent classes.

Considering how wretched and hopeless the life of a cripple needs must be, it should be our earnest aim to extend to them opportunities for becoming independent and selfrespecting.

The Trade School of the Hospital of Hope has been active during a period of business and financial depression recognized as the hardest known in twenty years. It has reacted upon the school in the efforts to secure positions for our men. It can readily be seen when 300,000 or more men are out of work an employer will not take recourse to a cripple when numberless able-bodied operatives are available. 
In spite of this handicap, the school has shown encouraging results and has proven that with a more general appreciation of the needs the problem of the cripple will be solved. 


\title{
A NEW FIELD OF WORK FOR CRIPPLED CHILDREN
}

\author{
MABel IRVing Barnes \\ New York
}

The Association for the Aid of Crippled Children has passed its second milestone. The first was in 1907 when the Auxiliary of the Avenue B Class for Crippled Children of the Children's Aid Society became an incorporated association under the present name, at which time the children concerned were admitted to special classes for crippled children in Public Schools 67 and 27. The second milestone referred to was reached last fall when the Board of Education took over the transportation of the children between the classes and their homes-a work which had been previously done by the Association.

To assure crippled children education in the public schools and the transportation facilities incident thereto has taken fourteen years of effort on the part of the Association, and now that this long chapter of its work is closed, it is starting on a new stage of its career.

After careful study of the needs of crippled children, of the causes responsible for their crippling, and of the various agencies working in their behalf, the Association sees clearly that, in its work, prevention is worth many pounds of cure. And it recognizes that prevention means two things: first, educating the public in general and parents in particular as to the causes of children being crippled, and pointing out the way of preventing them; second, by checking incipient crippling conditions in the babies. Having come to this conclusion, and realizing that its organization must be adjusted to its new functions, a committee was formed to consider the subject and the following plan was adopted. 
The offices were moved from Livingston Place, which was quite far down town, to the Charities Building. With the consent of the Babies' Welfare Association and the New York Milk Committee, part of Mr. Garrett Smith's time was secured as Executive Secretary of the Association. Mrs. Crawford, who had done such excellent work as superintendent of the Association, assumed charge of the active nursing department, and Miss Weston of the New York Milk Committee that of the survey department.

The active nursing department is continuing the same work the Association has always done. The nurses visit in the homes of the crippled children, teach the mothers proper methods of care, see that the children go to the dispensaries, and taking them there in the event of the parents' inability to do so. The nurses thus become the link between the homes and the hospitals or dispensaries. In the past the work was mainly among children attending or having attended classes in the public schools to which the Association transported them. Now, any child on Manhattan Island who needs such care can receive it from the Association. The Board of Education has instructed all school principals to refer crippled children to the Association.

The survey department is making a careful survey of Manhattan to find crippled children, keeping an especial lookout for incipient conditions among infants, and obtaining the help of the proper agency for their care.

Since the scope of the work has been so enlarged, the Association feels the need of medical advice, and it has therefore secured for consultation the services of Dr. Minor C. Hill, who is in charge of the health station of the New York Milk Committee. The orthopedic work is, as it always has been, in the hands of the orthopedic surgeon in charge of the individual child. A child needing treatment, who is not under care, is taken to the hospital best adapted to meet his or her special needs. 
By this close co-operation with the public schools, hospitals, and various philanthropic societies a proper division of labor is secured, and thus the energies and money of the Association can be centred on its special objects-home care of cripples and preventive work. 


\title{
A FIFTEENTH CENTURY PAINTER OF CRIPPLES
}

\author{
Douglas C. McMurtrie \\ New York
}

The cripple is not particularly well represented in the history of art, and few artists have taken him as a subject of their compositions. Pictures of dwarfs, especially those who served as jesters at the various courts, will be frequently encountered, but the models in these cases would not be legitimately classed as cripples. Velasquez, among others, of ten utilized such subjects. And portrayals of blindness and the blind, as, for instance, by Rembrandt, will be found in considerable numbers.

The one field where the cripple seems to figure to any appreciable extent (with but one or two exceptions), is in the paintings depicting miraculous cures. Thus there are a number of works representing St. Anthony healing the foot of the young man or the cure of the paralytic at the door of the temple.

But there are two artists who seem to have had an especial penchant for cripples as subjects for their work. One of these was Jerome Bosch and the other was Pieter Breughel, the Elder. Two specimens of the former's work will be presented with this note.

Jerome Bosch, this being the name generally given, from his birthplace, Hertogenbosch, to Hieronymus van Aeken, was a Dutch painter who lived from 1460 to 1518 . He devoted himself to the invention of bizarre types and diableries. He was a satirist much in advance of his time, and one of the most ingenious and original artists of the fifteenth century.

As has been stated, he frequently took cripples as subjects of his work. Two examples are reproduced herewith. The 


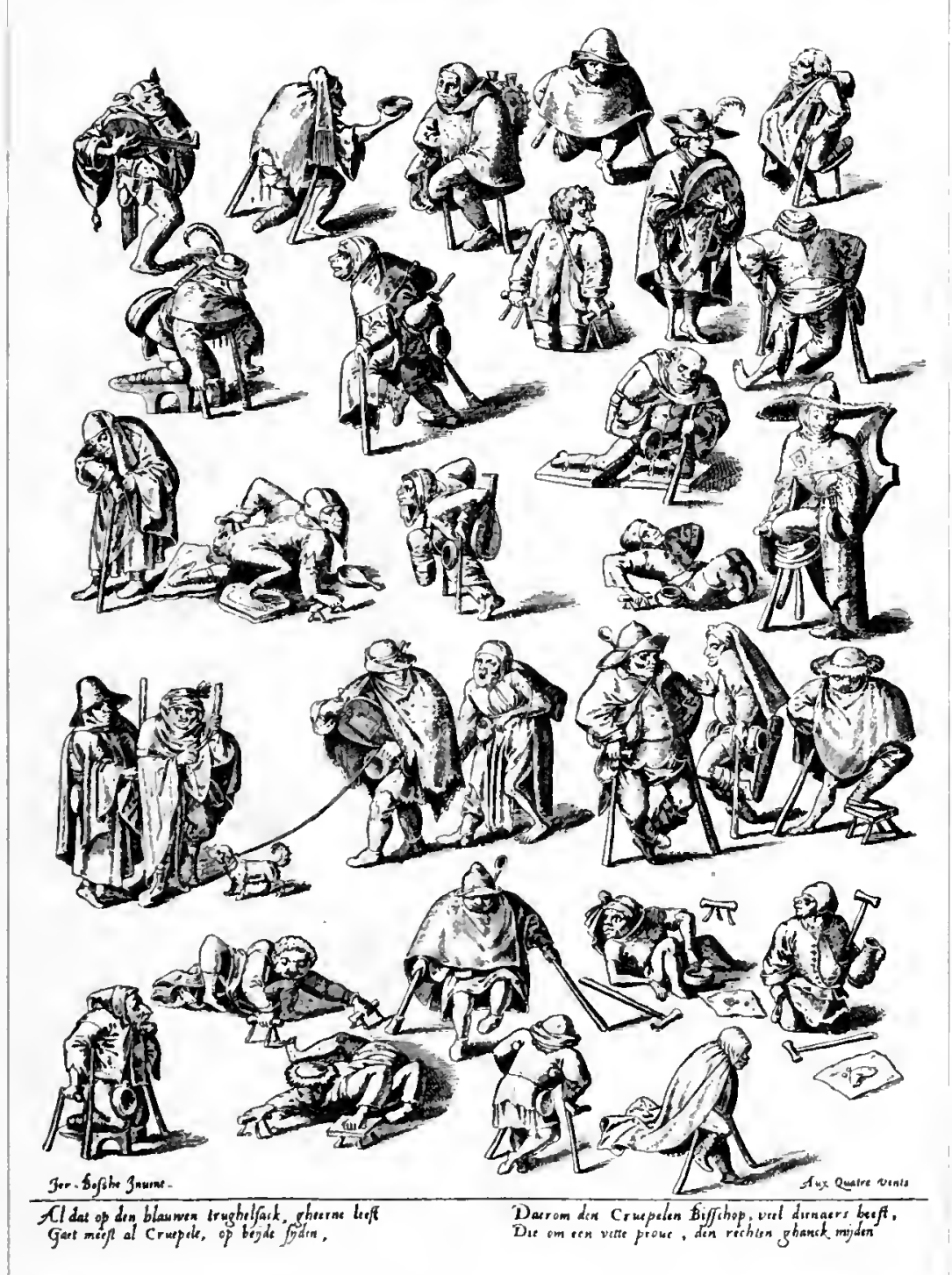

CRIPPLE PROCESSIOX, BY JEROME IBOACH 


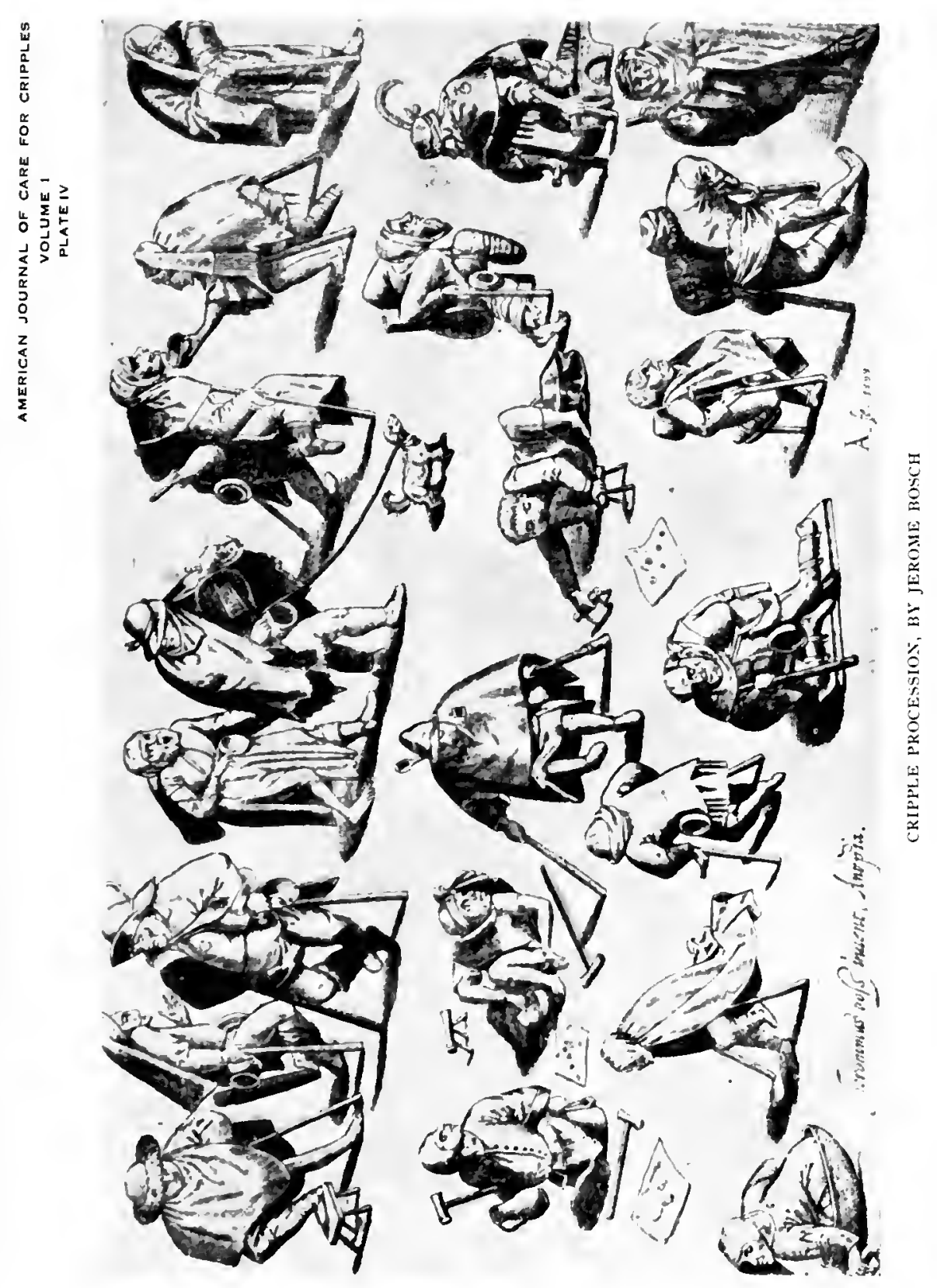



details will repay inspection as they have considerable curious interest.

The first subject (Plate III) is entitled 'A cripple procession.' It is interesting to note the various types of deformity and also the appliances which are used. Particular attention is directed to the small horses by means of which the seriously maimed are enabled to use their hands to assist in getting about. I am indebted for this plate to Holländer's work on medical factors in classical painting. ${ }^{1}$

The second illustration (Plate IV) is of a similar subject. The original is, like that of the first plate, an engraving. For this plate I am indebted to Richer's study of art and medicine. ${ }^{2}$

'Eugen Holländer. Die Medizin in der klassischen Malerei. 2d edit., Stuttgart, 1913, p. 231.

'Paul Richer. L'art et la médicine. Paris, n. d. p. 377. 


\section{COUNTRY HOMES FOR CRIPPLED CHILDREN IN THE VICINITY OF NEW YORK}

Data regarding homes for crippled children located in the country in the vicinity of New York were collected early this summer by the Federation of Associations for Cripples. As this material may serve not only as a guide for the placing of children but also to give an idea regarding the extent of the local facilities, and some of the principles of their maintenance, it is presented herewith.

Some of the institutions listed are country homes maintained by city institutions, while others are independent institutions located permanently in the country and open all year. The distance from New York is expressed in the time required to make the trip by the usual means of transportation employed. The accommodation, as usually stated, is approximate, being based in some instances on the capacity of the home and in others on the number of children actually being cared for. A preliminary medical examination is required by all the institutions; all exclude cases of pulmonary tuberculosis; and all receive children of various nationalities.

Blythedale Convalescent House for Tubercular Crippled Children. Location, Hawthorne, N. Y. Distance from New York, one hour. Round trip fare, \$1.25. Charges, free. Accommodation, 32. Age, girls, four years and up; boys, four to eight. Physical types admitted, tubercular bone cases. Length of stay, open all year.

Crippled Children's East Side Free School, 157 Henry Street, New York. Location, Oakhurst, N. J. Distance from New York, an hour and a half. Round trip fare, children 55 cents, adults \$1.05. Charges, free. Accommodation, 106. Age, four up. Physical types admitted, any cripples. Length of 
stay, two weeks to ten weeks. Remarks, take only children who are with them during the winter.

Day Home and School for Crippled Children, Public School 68, 116 West 128th Street, New York. Location, Bartow, N. Y. Distance from New York, half hour. Round trip fare, 30 cents. Charges, free. Accommodation, 40. Age, girls, six up; boys, six to fourteen. Physical types admitted, any cripples. Length of stay, two months.

Darrach Home for Crippled Children, 118 West 104th Street, New York. Location, Pelham Bay Park, N. Y. Distance from New York, one hour, but the trip is usually made by motor and consumes less than an hour. Round trip fare, twenty cents. Charges, free. Accommodation, 20. Age, four to sixteen. Physical types admitted, any cripples. Length of stay, three to four months. Remarks, take only children who are with them during the winter.

Daisy Fields Home and Hospital for Crippled Children. Location, Englewood, N. J. Distance from New York, forty-five minutes. Round trip fare, thirty cents. Charges, free. Accommodation, 18. Age, three up. Physical types admitted, any cripples. Length of stay, open all year.

House of the Annunciation for Crippled and Incurable Children, Broadway and 155 th Street, New York. Location, Wilton, Conn. Distance from New York, one hour. Round trip fare, $\$ 2.20$. Charges, free. Accommodation, 30. Age, four to sixteen. Physical types admitted, any cripples. Length of stay, four months.

New York Home for Destitute Crippled Children, 141 West 61st Street, New York. Location, Patchogue, L. I. Distance from New York, one hour. Round trip fare, \$1.68. Charges, free. Accommodation, 30. Age, four to fourteen. Physical types admitted, any cripples. Length of stay, five to six months.

New York Orthopædic Dispensary and Hospital, 126 East 59th Street, New York. Location, White Plains, N. Y. Distance from New York, forty-five minutes. Round trip fare, 
ninety cents. Charges, free or pay if able. Accommodation, 104. Age, four to sixteen. Physical types admitted, any cripples. Length of stay, open all year.

New York Post Graduate Hospital, 20th Street and Second Avenue, New York. Location, Southampton, L. I. Distance from New York, three hours. Round trip fare, \$4.57. Charges, free. Accommodation, 25. Age, up to eighteen. Physical types admitted, any cripples. Length of stay, three to four months. Remarks, take only children who are with them during the winter.

Seaside Home for Crippled Children. Location, Arverne, L. I. Distance from New York, half hour. Round trip fare, forty-five cents. Charges, free. Accommodation, 25. Age, approximately six to sixteen. Physical types admitted, any cripples. Length of stay, two weeks to three months. Remarks, for information during the winter, address Miss E. Goldsmith, 1230 Amsterdam Avenue, New York.

Sea Breeze. Location, West Coney Island, New York. Distance from New York (Manhattan), an hour and a half. Round trip fare, thirty cents. Charges, free. Accommodation, 43. Age, up to twelve. Physical types admitted, any cripples. Length of stay, open all year.

Miss Spence's School Society, Boat Southfield, East 26th Street, New York. Location, Port Jefferson, L. I. (temporary arrangement for this summer only). Distance from New York, two hours. Round trip fare, $\$ 2.97$. Charges, free. Accommodation, 20. Age, six to fifteen. Physical types admitted, tubercular bone cases. Length of stay, two months, Remarks, take only children who are with them during the winter.

William H. Davis Free Industrial School, 471 West 57th Street, New York. Location, Claverack, N. Y. (Lulu Thorley Lyons Home.) Distance from New York, about three hours and a quarter. Round trip fare, $\$ 4.50$. Charges, free. Accommodation, 50. Age, four to twenty-one. Physical types admitted, any cripples. Length of stay, three and a half months. 
House of St. Giles the Cripple. Location, Garden City, L. I. Distance from New York, 38 minutes. Round trip fare, \$1.02. Charges, free or pay if able. Accommodation, 65. Age, up to thirteen. Physical types admitted, any cripples. Length of stay, open all year.

St. Charles Hospital for Crippled Children. Location, Port Jefferson, L. I. Distance from New York, two hours. Round trip fare, \$2.97. Charges, free or pay if able. Accommodation, 178 cripples. Age, up to sixteen. Physical types admitted, any cripples. Length of stay, open all year.

There should also be considered the two cottages of the Children's Aid Society, mentioned on pages 98-99 of the present issue. 


\title{
THE MENTALLY DEFECTIVE CRIPPLE
}

\author{
Douglas C. McMurtrie \\ New York
}

The following notes present an abstract of the papers and discussion regarding the mentally defective cripple at the semiannual meeting of the Federation of Associations for Cripples, April 11, 1914.

The first paper on the subject was by Miss Adela M. Smith, but was read by Mrs. Helen $K$. Travers. This paper opened as follows: "While the problem has been agitated ever since special classes have been started for the education of the physically handicapped child, still no systematic plan for the training of the mentally defective cripple has been successfully carried out as the large number now without training in the City of New York shows. In practically all the schools, institutions, and classes for the education of cripples throughout the country, it is agreed that the mentally defective cripple has no place with the mentally normal cripple. Here the problem stands to-day."

Regarding classification, "generally speaking, the mentally defective cripples may be classed in two groups-the low grade mental defective and the high grade mental defective. These may be respectively designated as the institutional type and the non-institutional type. For the latter group, we have classes and proper facilities for training in our public schools."

Miss Smith then described a systematic study which had been made for several years in one of the public schools having classes for crippled children, to decide just what possibilities there were for educating the mentally defective cripple in the schools. "In one of the classes over $50 \%$ of the crippled children were found mentally deficient, and many of these physi- 
cally helpless besides. It did not take long to see that it was impossible to give such children proper training when associated with the mentally normal cripples, nor was it just to the latter. These children were then placed in a class by themselves, and again it was evident that the high grade mentally defective cripple and the low grade mentally defective cripple needed different treatment. Even the most enthusiastic and patient teacher found it a problem to give proper training to such children under existing circumstances. A teacher with strong personality who is a good disciplinarian can do much during school hours, but for eighteen hours daily these children are at home and on the streets, unguided and without the power of selfgovernment. As they grow older, the problem is increased in the gravity of results. Even though trained in school to do one occupation well, they are unable to continue when they finally leave school, because they are the tools of every influence with which they come in contact."

The reluctance of parents to allow feeble-minded children who had not committed some criminal act to be taken to an institution some distance away from home was then mentioned by Miss Smith. It would therefore be desirable to have a local institution for their care. Her conclusions were as follows: first, there is need for the segregation of the low grade mentally defective cripple in an institution or school; second, there is need of a suitable institution or school within the city for these children, with a special course of both physical and mental training to exact from these children the best that is in them, making them thereby practically self-supporting.

Miss Mary V. Fennessy, supervising nurse of the Brooklyn Bureau of Charities, gave a brief outline of the work for crippled children carried on by that bureau under the Fox bequest. It was decided that the best way of furthering the interests of crippled children was to co-operate with already existing hospitals. There has therefore been provided a nurse to assist the surgeon-in-chief at the Brooklyn Hospital and the Long Island 
College Hospital. There is also a 'census' nurse who attends to the children in the cripples' classes in the public schools and who looks after the interests of such other crippled children as she may find. The primary concern is with children under sixteen years of age.

Miss Helen Hamilton, inspector of ungraded classes in the Jersey City public schools, spoke of the present situation as regards the instruction of mentally defective cripples in the public school system. She pointed out that the crippled child must of ten be taught on the same basis as the mentally defective child because the former, by reason of his illness, is frequently also sick in mind. It is impossible to give adequate care and instruction to low grade defectives in public school classes. There should be a law forcing parents to send such children to institutions. She concluded by saying that she believed there was no place in the public school system for the mental defective.

Dr. Max G. Schlapp, director of the Clearing House for Mental Defectives, was the next speaker. He began by expressing his entire agreement with Miss Hamilton's last statement, taking exception to the opinion expressed in Miss Smith's paper that high grade defectives should be retained in the public school system. He said that the high grade defective is more dangerous than the low grade, because of the fact that the former is both less liable to detection and more aggressive. Also the possible criminal tendencies of the high grade defective are liable to more active expression. He considered female high grade defectives to be especially dangerous; he frequently came in contact with cases of this type where girls had been assaulted and offspring had resulted. He said that a view such as Miss Smith took was misleading to the public; and that all should unite in the idea that feeble-minded persons ought to be segregated. If the parents can surround a mentally defective child with proper care and protection they should be allowed to keep the child under their care; otherwise the child is a 
menace to society and segregation should be compulsory. Dr. Schlapp stated that European statistics showed that a very small percentage of feeble-minded persons could ever become self-supporting. About $90 \%$ are never able to maintain themselves. If we mislead these individuals into believing that they can become self-supporting and allow them to marry and have offspring we are wrong. All should unite to make the State provide institutions for delinquent feeble-minded, separate from other delinquents and from other feeble-minded persons. There are 35,000 mentally defective persons in the State of New York, and the institutions in existence to-day can accommodate only about 5,000. Our almshouses receive feeble-minded persons who are kept there for a time and are then allowed to go back into the community. Their children are often sent to institutions and from these institutions are placed out for adoption by private families. To consider the problem of the mentally defective there has been appointed a state commission which will report in 1915. If everyone supports the findings of the commission it will be necessary for the legislature to act and provide the institutions demanded. Dr. Schlapp then gave an outline of the work of the Clearing House for Mental Defectives and stated that he would be glad to receive and examine any cripples who might be referred there.

The meeting was then thrown open for general discussion.

Dr. Hastings H. Hart, of the Russell Sage Foundation, agreed with Dr. Schlapp that segregation was necessary for both high and low grade mental defectives. It is only since we have had compulsory education laws that the mentally defective children have come to light. The schools are performing a most important office in discovering these children; as they failed to advance, the lower grades became clogged and it became necessary to establish special classes for the feeble-minded. Dr. Hart spoke especially of the treatment of mentally defective crippled children. Every crippled child should liave first of all hospital treatment. There is no reason for having special hos- 
pitals for mental defectives, but the question of providing convalescent care for them separate from the normal children is a serious one. All of our hospitals are developing connections with convalescent homes for normal children, but the convalescent feeble-minded cripple should be given preference in institutions for the feeble-minded and should be sent to such institutions from the hospital where he was treated with recommendations regarding the proper physical care required for his complete recovery-from the orthopedic point of view. It should be possible to follow up hospital treatment immediately by adequate convalescent care. We already have institutions for helpless feeble-minded people, and it should not be necessary to create a separate class of institutions. The problem can be worked out on the existing plan.

Mrs. Harrison Gray Lamson next asked whether Dr. Schlapp meant to recommend the establishment of one large institution for the feeble-minded. Dr. Schlapp said that this was not his idea; he preferred many small institutions. Mrs. Lamson agreed in this opinion, considering it extremely difficult to provide proper training for defective children in large institutions.

Dr. Hart suggested that the plan at Letchworth Village was in accordance with her idea-that is, a very large tract of land on which there are many small buildings, Dr. Hart considered that no institution should contain more inmates than could be known personally to one superintendent. Our local system of legislation is wrong. In the State of Wisconsin there is provision whereby a new asylum for the insane can be built when needed without special action by the legislature. Wisconsin is the only state in the Union which does not have overcrowding in its institutions. In New York State, however, we shall have to develop along present lines as well as possible. The Letchworth Village plan is a good one.

Miss Louise Scudder, of the Ladies' Auxiliary of the Orthopedic Ward of the Post Graduate Hospital, asked what was the proportion of feeble-minded children of feeble-minded parents. 
Dr. Schlapp replied that there were no accurate figures on the subject. He said there were three distinct classes of feebleminded persons.

Dr. Hart asked if feeble-mindedness were not hereditary in the majority of cases. Dr. Schlapp said it was congenital rather than hereditary, that its appearance was often sporadic. Dr. Hart stated that he believed, from statistics now necessarily inaccurate but which would be brought up to a point of real value in the next twenty-five years, that feeble-mindedness was hereditary in the majority of cases. 


\section{CONTRIBUTED NOTES}

PUBLIC SCHOOL WORK FOR CRIPPLES IN BALTIMORE

A little more than two years ago the Baltimore School Board, at the request of the trustees of the Kernan Hospital for Crippled Children, and also of the Maryland Hospital for Crippled Children, provided teachers and equipment for giving to this kind of children academic work suited to their abilities and related to such hand work as they were able to do. This year two additional classes for these children were established in two regular school buildings in the city, thus making in operation this year four classes. The total number of children enrolled during this year to May 31 is 95 . Of this number 33 were withdrawn by reason of change of residence, of removal from the hospital, or other causes, leaving a net register of 62 on May 31. The average daily attendance in the classes has been 51 .

In the regular school classes as well as in the hospital classes both academic and manual work are provided. It is not expected to give them full grade work unless they are entirely able to take it up, and even then a great effort is made to relate it directly to their life interests. This is the controlling principle also in manual work. Considerable use is made of weaving, passing through the simpler forms to the use of the weaving loom. Some of these children are able to do very good work on the loom and it has served a good purpose as I shall mention below. Chair caning is also taught them, and sewing to those who are able to use their hands with facility. The instruction is entirely individual. All of the classes are in session from $9 \mathrm{a} . \mathrm{m}$. to $1 \mathrm{p} . \mathrm{m}$. In three of them lunch is provided for the children.

At the inception of the two classes in regular school buildings, a body of patrons co-operated by furnishing means for the transportation of the children to and from the schools. Last 
year, however, there was secured the co-operation of the Police Department, who placed their ambulances at our service for the hour in the morning and the hour shortly after noon needed for transporting these children. They have been more than kind, and have had a sign, 'School Ambulance,' made to cover the Police Department lettering on these wagons. The children appreciated the kindness so much that they made a number of rather pretty rugs and sent them to the office of the Police Department. The officers at once determined to show their appreciation, and, with the co-operation of the Tolchester Steamboat Company, the police officers took these little crippled children down the bay on an excursion. I only mention this to show the admirable spirit that prevails.

The Department of Education has thus demonstrated its attitude toward this work and undoubtedly they will extend it as need therefor becomes evident.

EDwin Hebden.

WORK OF THE DRIVING FUND

The work of the Crippled Children's Driving Fund has been under way this season since April 18. $\mathrm{U}_{\mathrm{p}}$ to the middle of June about one thousand crippled children had been taken for weekly drives in Central and Prospect parks, and to other points of interest. Children attending the special classes for cripples in the various public schools have been taken, with their teachers, on trips to the Aquarium, the Navy Yard, the Menagerie, the Metropolitan Museum of Art, and the American Museum of Natural History. There have been several parties taken to the theatre and the 'Wild West' show.

The present offices of the Driving Fund are at 1526 East 15 th Street, Brooklyn.

BERThA SMith. 


\section{PUBLIC SCHOOL CLASSES IN CHICAGO}

The crippled children of Chicago, who need special care and are not too badly crippled to leave their homes, are taken care of in two special schools provided for this purpose. At each of these a specially equipped building is provided with bath room, rest room, kitchen, dining room, etc. Children are brought to the school in 'busses, thirteen or fourteen of which are now in use, and at the end of the day they are again taken to their homes.

At cach school an ample lunch is served at noon, consisting of soup, stews, vegetables, bread and butter, milk, boiled rice, etc. The expense of this is borne by the Board of Education. A woman attendant at each school does the cooking and also helps in giving such special care as the children may need. A physician calls at each school daily to look after such cases as need special attention. At present seven teachers arc employed in this work, each with twenty to twenty-five pupils.

The Board of Education is about to install a motor 'bus service to cover parts of the city which so far have been out of reach, and this may result in the increase of the number of teachers.

E. C. Rosseter.

\section{WORK OF THE BREARLEY LEAGUE}

This year completes the sixth year that the Brearley League has carried on the Trade and Manual Training classes for crippled children, and it is most encouraging to see what great benefit the children have derived from them.

The total attendance of scholars is............ 82

The average attendance of scholars is . . . . . . . 72

Number of teachers employed by the Brearley League.. 14

Number of teachers employed by Children's Aid Society under the direction of the Brearley League......... 3

Number of classes held...................... 7 
The classes are as follows:

1. Preparatory Manual Training.

2. Advanced Manual Training.

3. Jewelry.

4. Preparatory Sewing.

5. Downstairs Branch of Preparatory Sewing.

6. Dressmaking.

7. Embroidery.

A trained nurse is employed.

The two Trade Classes participated in two exhibitions this year, and although they might have done considerably better in orders, it is felt that by our co-operation with the five other associations who belong to the Federation of Associations for Cripples, the classes have been advertised and are being recognized more by the public.

Louise BALDWIN.

\section{ANNIVERSARY CELEBRATION}

The Good Shepherd Home, of Allentown, Pa., for crippled orphans, blind orphans, infant orphans, destitute children, old people and aged or disabled ministers, will celebrate its sixth anniversary on August 6, 1914. Over four thousand people were present at last year's anniversary.

The youngest child admitted into the Home was less than one day old, and the oldest person in the old people's department was 107 years old on September 11, 1913. The Home has 47 children at present, 15 of whom are crippled, 3 cannot even walk with crutches, 4 are totally blind, 1 almost blind, 3 cannot speak, 1 cannot move, and 27 were babies when they were brought. It is a Lutheran institution, but receives children and old people regardless of creed, color, or nationality. The Home is supported by voluntary contributions.

JOHN H. RAKER. 


\section{EDITORIAL NOTES}

\section{FEDERATION OF ASSOCIATIONS FOR CRIPPLES}

The Federation has been continuing active work during recent months. New cases come in daily and old ones are being carried on and finished. A folder has been issued explaining the work in concise form. A list of summer homes, their location, the railroad fare required to reach them, and other pertinent information are on file at the office. Funds are being raised through the creation of associate members.

The Federation is undertaking a census of cripples in Greater New York. Cards have been distributed and are at present being filled out by all agencies that come in contact with cripples. These cards are to be placed on file, and kept revised up to date in the Federation office. There is a crying need for accurate statistics regarding cripples in New York, and the Federation is confident that such a census, checked and completed by the school census and also by other means, will prove of great value to all who work with cripples.

Miss Eva Rorty is finishing her winter's work with the Fedcration, and Miss Winifred Putnam will be in charge during the summer. Miss Adler is doing active work again as chairman of the executive committee. Mrs. Helen Travers is acting chairman of the publication committee in the absence of Miss Adelaide Baylis.

\section{SEMI-ANNUAL MEETING OF THE FEDERATION}

The semi-annual meeting of the Federation of Associations for Cripples was held at the Y. W. C. A. Building, on April 11, 1914. The president, Mrs. George F. Shrady, announced some changes in the officers of the Federation, Mr. Thomas S. McLane 
having succeeded Miss Edith Bond as treasurer, and Mrs. Ernest Strauss having been appointed recording secretary. Some proposed amendments to the constitution were then read and adopted.

The president announced that there had been created a new class of members to be known as associate members and made up of persons contributing not less than two dollars annually. The statement was made that, for the coming year, the Federation would need at least $\$ 1,500$.

It was then announced that the special subject for discussion was 'The Mentally Defective Cripple.' A report of this discussion is given in an article in the current issue of the JourNal.

\section{WELFARE COMMISSION FOR CRIPPLES}

A national organization with the object of promoting the interests of cripples has been in existence for some time-the 'Welfare Commission for Cripples,' there being associated in its membership many of the most prominent orthopedic surgeons in the country as well as several lay persons active in work for the deformed.

This Commission had projected and almost entered upon the publication of a bulletin dealing with subjects related to care for cripples at the time the AMERICAN Journal of CARE FOR Cripples was started. Dr. H. Winnett Orr of Lincoln, Nebras$\mathrm{ka}$, who had been the moving spirit in the organization of the Commission, on being apprised of the publication plan being perfected in the East, generously suggested the abandonment of the Commission's projected bulletin and co-operation with the other enterprise, $i$. e., the present JournaL. This was consented to by the members of the Commission. It should be noted, however, that the Commission had already started its campaign and had secured several members of various classes. After the coalition of the publication projects it was decided to defer further arrangements until the time of the annual meeting of the Commission. 
This annual meeting was held at the Bellevue-Stratford Hotel, Philadelphia, Pa., on the afternoon of June 20, following the convention of the American Orthopedic Association. It was decided that this Journal should be sent, in so far as possible, to members of the Commission who had already contributed, and that some agreement should be made whereby new contributors should also receive it. The details of this matter were delegated to the vice-president and treasurer with power to act. The Journal was designated as the official organ of the Commission.

There being a vacancy among the Commissioners, whose number is fixed as fifteen, Mr. Douglas McMurtrie was elected to the board.

In the election of officers for the ensuing year the following were named: president, Dr. Arthur J. Gillette, of St. Paul, Minn.; vice-president, Dr. H. Winnett Orr, of Lincoln, Neb.; secretary, Mrs. Edith Reeves Solenberger, of Lansdowne, Pa.; treasurer, Dr. John L. Porter, of Chicago, Ill.; editor, Mr. Douglas C. McMurtrie, of New York.

It was decided to establish a central bureau for the collection and distribution of literature, pamphlets, reprints, and the like, bearing on the welfare of cripples. This work was delegated to the secretary.

The membership of the Commission as at present constituted is as follows: Dr. Leonard W. Ely, San Francisco, Cal.; Dr. A. H. Freiberg, Cincinnati, Ohio; Dr. Arthur J. Gillette, St. Paul, Minn.; Dr. Michael Hoke, Atlanta, Ga.; Dr. Robert W. Lovett, Boston, Mass.; Mr. Douglas C. McMurtrie,New York City; Dr. John L. Porter, Chicago, Ill.; Dr. H. Winnett Orr, Lincoln, Neb.; Hon. Howard Kennedy, Lincoln, Neb.; Dr. John Ridlon, Chicago, I11.; Dr. Harry M. Sherman, San Francisco, Cal.; Dr. David Silver, Pittsburgh, Pa.; Mrs. Edith Reeves Solenberger, Lansdowne, Pa.; Hon. George W. Sweney, Marion, Ohio; Dr. H. Augustus Wilson, Philadelphia, Pa.

As a matter of record and for purposes of information as to 
the objects and organization of the Commission, its constitution is given herewith. It will be noted that recent developments have caused the original plan of action to be altered in one or two slight details.

CONSTITUTION OF THE WELFARE COMMISSION FOR CRIPPLES

Article I. Name.

This organization shall be known as The Welfare Commission for Cripples.

ARTICLE II. Object.

The purpose of this organization shall be to concern itself with the welfare of cripples in the United States.

1. By the publication of a Bulletin to be known as the Bulletin of the Welfare Commission for Cripples.

2. By the establishment and maintenance of lectureships.

3 . By the publication and distribution of any literature calculated to contribute to the welfare of cripples.

Or in any other way decided upon which shall (a) point out the need for special care and special training of the crippled and deformed and those suffering from deformity-producing diseases, or (b) show what can be accomplished for this class of patients by modern methods of education and care.

ARTICLE III. Government.

Sec. 1. The conduct of the affairs of the Commission shall be entirely by a Board of fifteen members.

Sec. 2. No action affecting the policy of this Commission may be taken by any member without the proposed action having been submitted in writing to all of the board of Commissioners and approved by a majority of the members.

Sec. 3. No expenditure of the funds of the Commission of any amount exceeding $\$ 5.00$ may be made or authorized by any member of the Board of Commissioners except in the same way. 
Article IV. Members.

There shall be four classes of members as follows: Commissioners, Honorary, Sustaining, and Subscribers.

a. Members of the Board of Commissioners shall be elected upon the showing that the candidate is especially interested in, or has distinctly contributed to the welfare of cripples. Elections to the Board shall occur only at the annual meeting and when a vacancy in the required number (15) exists. A twothirds vote of these present at the annual meeting shall be necessary to elect.

b. Honorary members shall be members of the American Orthopedic Association and any others proposed by an Honorary Member or a Commissioner and receiving the unanimous vote of the Board at the annual meeting.

c. Sustaining members and subscribers shall qualify as provided in Article VII.

Article V. Officers.

The officers of the Commission shall be a President, VicePresident, Treasurer and Secretary-Editor, each of whom must be a member of the Board of Commissioners and elected for a term of one year at the annual meeting.

Article VI. Meetings.

There shall be an annual meeting of the Board of Commissioners during the annual meeting of the American Orthopedic Association at the same place and at a time agreed upon.

ARTICLE VII.

Commissioners and Honorary Members shall be exempted from the payment of any fee. Sustaining members shall pay a fee of $\$ 10$ per year which shall entitle them to receive the Bulletin as issued and have it sent for the year to four other persons, also to receive all other literature distributed by the Commission and free admission to all lectures given under the auspices of this Commission. Subscribers shall pay a fee of 
$\$ 2.00$ per year which shall entitle them to receive the Bulletin and free admission to lectures.

There shall also be published continuously in the Bulletin a list of Benefactors who have contributed to the objects of this Commission $\$ 100.00$ or more at one time.

\section{A CHANGE OF NAME}

In the list of members of the Federation in the first issue of this Journal, the name of the 'Ethical Culture Visiting Guild for Crippled Children' appears. That organization has ceased to go under that name and is now known as the 'Blythedale Home for Convalescent Tubercular Cripples.'

\section{AN INSTITUTION IN THE FAR WEST}

An institution for crippled children in the far west eluded for some time the notice of those who were studying American facilities for the care of the deformed, but information regarding it has now come to light. The Children's Orthopedic Hospital of 2107 Warren Avenue, Seattle, Washington, is now in its eighth year of work. With the exception of the medical and surgical work the activity of the hospital is entirely in the hands of women, the officers and the trustees. No salaries are paid except to the nurses, helpers, and bookkeeper. More detailed information regarding this institution is promised the Journal for an early issue.

\section{STENOGRAPHY AT EAST SIDE FREE SCHOOL}

A class in stenography and typewriting for the older boys has been established at the Crippled Children's East Side Free School, 157 Henry Street, New York City. This class, under a competent instructor, was started February 1, 1914, with an enrollment of twenty-two. It is in session six hours a week. Much interest is shown by the boys, and the teacher reports satisfactory progress. 
AMERICAN ORTHOPEDIC ASSOCIATION

The twenty-eighth annual meeting of the American Orthopedic Association was held at the Bellevue-Stratford Hotel, Philadelphia, Pa., June 18-20. There was a full programme of papers, all of a scientific nature.

\section{AMERICAN OPEN AIR SCHOOL ASSOCIATION}

A matter which should be of interest to those concerned in the education of crippled children is the organization of the 'American Open Air School Association.' This association will urge the extension of open air classes, not only for tubercular, crippled, or anemic children, but for healthy children as well, the idea being that fresh air should not be reserved for ailing children alone. Its platform holds that "the open air school must become the rule, and the closed room the exception." The secretary is Dr. Walter W. Roach, and the headquarters of the Association are at 1140 Real Estate Trust Buildings, Philadelphia, Pa.

The next meeting of the Association will be held in Philadelphia, September 22-29, in conjunction with the Fourth International Congress on Home Education.

YEAR'S WORK OF ST. CHARLES HOSPITAL

The census of St. Charles Hospital for Crippled Children, Port Jefferson, L. I., was 194 children. The great majority of these, 175 , were cripples, but there were also a few other physically handicapped children of other classes, as follows: 14 blind, 4 deaf, and 1 deaf, dumb, and blind. During the past year there were 109 admissions and 68 discharges. A full account of the work of this institution will appear in a subsequent issue.

\section{SUMMER COTTAGES FOR CRIPPLED CHILDREN}

In a booklet ${ }^{1}$ relating to its summer charities the Children's Aid Society makes mention of its vacation work for crippled

${ }^{1}$ Summer Charities of the Children's Aid Society. New York, 1914, p. 8-9. 
children. An illustration of the Haxtun Cottage and several pictures of crippled children are included. "Connected with the Children's Summer Home [at Bath Beach] is the Haxtun Cottage for Crippled Children, with accommodation for 16, who remain for two weeks or longer. This cottage was designed especially for these afflicted little ones and in its equipment nothing has been omitted that would add to their comfort and happiness. Besides this cottage for crippled children at Bath Beach, another cottage was set aside for them at Chappaqua. At both places, 173 crippled children were entertained last summer for periods ranging from two to four weeks."

\section{EDITORIAL COMMENT ON THIS JOURNAL}

After the issue of the first number of this JouRnal there appeared various reviews and comments on the project in the scientific press. The most extensive comment took the form of a leading editorial ${ }^{2}$ in the Medical Record, a periodical of wide circulation, and one of the best known medical journals in the country. The text of the editorial is given below.

\section{The Care of Cripples in the United States}

To care for cripples properly is now recognized as the bounden duty of every civilized community. Such care is to a great extent an index of the degree of civilization to which a nation has attained and unfortunately also the number of physically deformed is more or less a criterion of civilization. The more a country is engaged in industrial pursuits, the larger is its number of cripples likely to be. Regarded from this standpoint the United States is certainly a very highly civilized country for in the number of its cripples it takes a foremost position. However, with regard to its care of those mained by disease, by accident, or congenitally, the United States is also in the front rank, and, as in European countries, the right of such persons to be educated so as to be self-supporting, if possible, and in any event to have their way made comparatively smooth, is being more and more appreciated.

${ }^{2}$ The care of cripples in the United States. Medical Record, New York, 1914, Ixxxy, 805 . 
A practical illustration of the concern manifested in the welfare of cripples has been afforded recently by the appearance of the first number of the American Journal of Care For Cripples, edited by Douglas C. McMurtrie, assisted by an editorial board of medical men, and published by the Federation of Associations for Cripples. The publication committee consists of four lady members of the Federation, the president of the Federation being Mrs. George F. Shrady. The opening number is excellent and includes articles by Dr. Gwilym G. Davis of Philadelphia on the 'Education of Crippled Children,' by Dr. Augustus Thorndike of Boston on 'Industrial Training for Crippled Children about Boston,' by Katherine W. A. Shrady on the 'History of the Federation of Associations for Cripples,' by Mr. Douglas C. McMurtrie on the 'Early History of Care for Cripples,' by Dr. H. Winnett Orr of Lincoln, Neb., on 'A Statistical Estimate Relative to the Number of Cripples in the United States,' and by Grace F. Hardy of Boston on 'A Course in Basketry and Cane-seating.' The article by Dr. Davis, which was read before the Orthopedic Section of the New York Academy of Medicine, December 4, 1913, describes clearly the character of education suitable to crippled children of different kinds and the wonderful results often obtained. Dr. Davis points out that crippled children constitute a sort of middle class; they should not be driven as totally well children would be driven, nor should they be nursed as sick ones would be nursed. In other words, they should have a distinct, separate, special method of treatment of their own adapted to their peculiar needs. Katherine W. A. Shrady gives an interesting account of the history of the Federation and states that its general object is to co-ordinate the work of the various societies interested in cripples by the establishment of a central bureau, where a complete registry is kept of all homes, schools, hospitals, aid societies, fresh air agencies, etc., so that cripples may be referred there for information. The statistical estimate by Dr. Orr regarding the number of cripples in the United States places it at 259,754. The article by Grace F. Hardy is an outline of the course of basketry in the Industrial School for Crippled and Deformed Children in Boston. The journal is most commendable in its intention and if it lives up to the high standard of its first number it will be from the purely literary point of view of importance. It has a wide ficld of usefulness, for the lack of such a publication hampers considerably the work of societies endeavoring 
No. 2 .

to improve the lot of the crippled. The journal should and doubtless will be the means of disseminating information among the many rich and charitably disposed persons who are desirous of assisting those who in the battle of life have to contend with physical disabilities brought about by disease or accident.

MOVE TO A COUNTRY HOME

Each year about the middle of June the children of the Home of the Merciful Saviour in Philadelphia move to the summer home of that institution at Avon-by-the-Sea, N. J. According to the May issue of the Journal issued by the Home, their family all told now numbers seventy.

AID FOR THE VICTIMS OF WORK ACCIDENTS

A note regarding the work of a Paris Society in aid of cripples has recently come to hand. It concerns the 'Societé protectrice des invalides du travail.' This organization, founded in 1901, has its headquarters at 23 , rue de Londres. It procures employment suited to the capacity and abilities of persons injured or maimed in industrial accidents.

\section{A FRENCH SOCIETY FOR THE CRIPPLED}

Another Paris organization is the 'Association pour l'assistance aux mutilés pauvres,' founded by the Count de Beaufort in 1868, and located at 3, Place de la Madeleine. The aim is to assist necessitous maimed or crippled persons to a position where they can be wholly, or at least partially, self-supporting. This is accomplished either by furnishing the necessary orthopedic appliances, crutches, chairs, and the like, or by financial assistance where this is deemed expedient. Grants are made after consideration of individual applications.

HOME FOR INCURABLES IN BUFFALO

The Wheel Chair Guild of Buffalo changed its name in June, 1913, to the 'Wheel Chair Home for Incurables.' Its present address is 344 Hudson Street, Buffalo, N. Y. The institution 
receives adult incurables and chronic invalids who pay a certain amount towards their support, additional expenditures being met by charitable contributions. Thirty invalids have been registered since September 1, 1911. Another object of the organization is the provision of wheel chairs for invalids among the worthy poor of the city.

\section{STATE PROVISION FOR THE CRIPPLED}

The provision by state legislatures of care and education for crippled children has been an unique and creditable feature of American work. The political aspects of one of the leading state institutions have been described ${ }^{3}$ by Dr. H. Winnett Orr, Superintendent of the Nebraska Orthopedic Hospital. Some extracts from the article follow.

There are many reasons why the care and education of crippled children is naturally a state function. It has long been considered that the education and training of normal persons is a profitable thing for cities and states to do, but it is certain that a much larger proportion of those who are crippled become dependent if not made the object of special care. Economically therefore the state is simply using ordinary business foresight if by suitable hospital care and education these patients are treated and trained so as to become partially or wholly independent and self-supporting.

It has long been recognized that special institutions are necessary both for the hospital care of crippled children and for the education of those who are defective either physically or mentally. To me it has seemed for a long time that the combination into one institution of the hospital and school for crippled children is of special importance. We have found in the Nebraska Orthopedic Hospital that considerable progress educationally may be made by these patients while actually under treatment. Moreover, a continuation of their cducational training and the selection of occupations for them is probably more successfully done under the supervision of those who have administered their hospital care and who have a full appreciation of the physical and mental needs and qualifications of these patients.

'H. WinNert ORR. The relation of politics to the state care of crippled and deformed. Journal of the American Medical Association, Chicago, 1913, 1xi, 1521-1522. 
There are then given the details regarding the inception and development of legislative activity as it concerned the institution. Dr. Orr concludes as follows:

The epidemic of infantile paralysis in Nebraska in 1909, which gave us nearly one thousand more crippled children, has been a determining factor in the development of our work. We estimate that there are at present in our state between two and three thousand children who could be benefited or entirely cured and their education greatly facilitated by the methods employed in the Nebraska Orthopedic Hospital.

From these figures it is easy to infer something as to the situation in other states. Minnesota, through Dr. Gillette, was doing fine work along this line before Nebraska began. New York had also already established an institution for the state care of crippled children. Massachusetts since that time has built and is operating a great educational plant for its cripples. In all of the other states, however, this field is practically undeveloped. A few states like New York, Illinois, Maryland, Pennsylvania and Maine are doing magnificent work through contributions of private philanthropists, with or without state assistance. There is great need, however, for the awakening of the public conscience with regard to these patients. We have become prodigal in our expenditures for the education and training of normal children, while those most in need of special care and training are allowed by reason of neglect to drift further into a state of dependency.

The point to which I wish to call particular attention is that in some states, perhaps in many, no special effort has been made in this direction because of the fact that those who are most interested have expressed themselves as unwilling to 'mix in politics,' as they express it, or to resort to political methods to secure the appropriations to establish these necessary special institutions.

The lesson we have learned in Nebraska is that our members of the legislature and our state officers have been our best friends; that they have been quick to appreciate the possibilities of this work as well as the needs of the patients and that without their sympathy and support in this, as in any other public work, success would have been absolutely impossible. 


\section{A PUBLICITY BOOKLET}

There has recently been issued a booklet ${ }^{4}$ written and distributed for the purpose of stimulating interest in the work for crippled children being carried on by the New York Orthopædic Dispensary and Hospital. It begins by telling the story of one boy, a tubercular cripple, who was taken to the institution at a stage of his disease early enough to obtain the most advantageous results of treatment. Special emphasis is laid on the social aspects of the case. There is then given a description of the methods at work, illustrated by views of the city hospital in New York and the country branch at White Plains.

\section{ENLARGEMENT OF THE MUNICH INSTITUTION}

In a recent installment ${ }^{5}$ of correspondence from Germany appeared the note which is quoted below. The institution referred to, the 'Konigliche Zentralanstalt fur Erziehung und Bildung krüppelhafter Kinder,' is of particular interest as being the first modern establishment for the care of crippled children, founded in 1832. It is located in Munich, Bavaria.

March 26, the new building of the National Institute for Crippled Children, and the orthopedic clinic connected with this institute were formally opened in the presence of the King and Queen of Bavaria. The king gave the Institute a fund of $\$ 2,500$ (10,000 marks) for free beds. The National Institute consists of a large central building and two side wings. Through the entrance one passes into a main hall, from which is reached the large dining hall. Spacious corridors each side lead to the schoolrooms for boys and girls, the workrooms and workshops, such as the bookbindery, the tailor shop and the shoe shop. The gymnasium is connected with the latter by a corridor. On the second story of the main building there are offices, examination and operating rooms for the dentists and house physicians and a room for the drawing classes; in the wings are recreation rooms, play rooms, music rooms and bedrooms. The separation of the sexes is

1 Douglas C. McMurtrie. How Andy missed being a cripple. New York, 1914.

' Institute for crippled children in Munich. Journal of the American Medical Association, Chicago, 1914, lxii, 1489. 
carried out strictly. The third story contains, besides the apartments for the director, dormitories, rooms for the laundry and the sick rooms. Each dormitory is provided with an inspection room, a wash room, and wardrobe. In the upper story, to be used for the enlargement of the Institute, there will be placed at first only some reserve rooms, a sick room and a room for former pupils. Comprehensive provision for the boilers and kitchen, besides the baths and the rooms for the servants, are made in the basement.

A roomy passageway in the first story leads from the National Institute to the orthopedic clinic. Here also the kitchen with its accessory rooms and the rooms for servants, as well as the workshops for the preparation of orthopedic apparatus, are placed in the lower story. From the arched entrance hall, the office and waiting rooms as well as the numcrous consultation and examination rooms are accessible. The operating rooms, the special Roentgen-ray rooms and a patients' elevator, as well as the orthopedic gymnasium, lie in a transverse building adjoining on the south. The first and second stories of the clinic are chicfly occupied by rooms for patients in addition to a living room for the assistant, an operating room for scptic cases, a dining room for the nurses and two separate wards with five beds.

All the patients' rooms are provided with covered porches which face south or southeast. The number of beds for patients amounts at the outset to seventy, but they can be easily increased at any time by putting them closer together. The living rooms for the nurses are in the upper story of the south building. From the connecting passage between the National Institute and the clinic there are entrances to the Roman Catholic and Protestant chapels.

The isolation and laundry building serves in common for the $\mathrm{Na}$ tional Institute and the clinic. It contains in the basement scientific laboratories for animal experiments, disinfection apparatus and a room for generation of steam and hot water as well as an apparatus for softening the very hard water. On the ground floor and in the second story there are four isolation rooms as well as a special steam laundry for each of the two institutions. The heating of the whole building is carried on in a common heating plant. 


\section{PUBLIC SCHOOL CLASS IN PHILADELPHIA}

There is now a class for crippled children in the Philadelphia public school system. It is located in the Horace Binney School at Sixth and Spruce Streets. There are about thirty pupils in the class. A large closed 'bus, carrying a driver and one attendant, gathers the children up from their homes in the morning and returns them soon after half past three in the afternoon.

The children are given a morning recess lunch and mid-day luncheon. The schoolroom is equipped with desk furniture having adjustable back and leg rests. There is a matron in attendance all day.

Plans are now being made for the extension of the work and it is reported that there should soon be six such special classes for crippled children, located in various districts of the city.

The Superintendent of Schools, in his annual report, ${ }^{6}$ speaks of the class as follows:

The cost of transportation of the Orthopedic Class is an item which makes the per capita expenditure for this class larger than for any other class in the elementary schools. The results, however, are so strikingly important that I believe anyone acquainted with the details of the improvement in the physical and mental conditions of the pupils attending would feel this or even greater expensc fully justificd. The percentage of attendance has been as high as that for regular classes, and progress in school work has been good. Children of twelve years of age or more who could not read and write when admitted to the class, and who perhaps would never otherwise have. had the opportunity to learn, are advancing rapidly in regular good work, and will soon be pursuing studies normal to their age. A world of knowledge and enjoyment has been opened up to them, and, in some cases, useful employment, and partial, if not completc, self-support may be made possible.

Through the Division of Medical Inspection co-operating with the Social Service Department of the Orthopedic Hospital, regular

- Philadelphia, Board of Public Education. Annual Report of the Superintendent of Public Schools of the City of Philadelphia for the year ending December 13,1913. Philadelphia, 1914, p. 29-30. 
treatment by specialists has been secured for a number of the children most in need of it, with markedly good results.

There are enough applicants whose eligibility for such a class is now being investigated to warrant the establishment of another class in the same school. Report will be made upon this and other needs of similar character in other parts of the city. Our experience with the present class, I believe, will justify the formation of new classes as the need for such is clearly demonstrated.

\section{ESTABlishment OF THE PHILADELPHIA ClASS}

Some data regarding the steps leading up to the establishment of the public school class for cripples in Philadelphia are given $^{7}$ in the second annual report of the Social Service Department of the Philadelphia Orthopædic Hospital and Infirmary for Nervous Diseases.

In September, 1913, a special class for crippled children was established by the Board of Education on the basis of an investigation made under the supervision of this Department.

It was observed that many of the children suffering from orthopædic defects get a very interrupted education or none at all, owing to the time lost in receiving treatments and long sojourns in hospital wards, or to their total inability to attend. During 1912, the compilation of a list of children so handicapped was begun, and in the autumn of that year a preliminary investigation of fifty cases was made by two volunteers. In order to make the inquiry in the district chosen more complete, our own list was supplemented by names secured from the Bureau of Compulsory Education and the census made by the Committee on Municipal Charities.

This investigation showed that out of forty cripples found nearly fifty per cent. had never been to school at all, while almost as many more had attended very irregularly. Only six had an average school record. Many were entirely helpless, and over half were living under bad home conditions.

The results of the investigation were tabulated and, through the Public Education Association, were presented to the public school

'Social Service Department, Philadelphia Orthopædic Hospital and Infirmary for Nervous Diseases. Second Annual Report. Philadelphia, 1913, p. 11-12. 
authorities in February, 1913. The needs of this class of children had been under consideration for some time and the response was gratifying. It was decided to start a special class in September of this year and this Department agreed to assume the task of investigating additional cases reported in the two school districts chosen. Over a hundred families were visited or revisited during June and July. In this task the Social Service staff worked early and late and valuable assistance was given by a volunteer.

The class is now well established with an average attendance of twenty-four children, of whom over half are our own patients. The hearty co-operation of our doctors has been a great factor in the establishment and success of the class. At the suggestion of one of our surgeons we have just completed an arrangement for a volunteer from our Massage Department to give treatments at the school to those needing it. 


\section{BIBLIOGRAPHICAL NOTES}

In this section, which appears for the first time this issue, will appear editorial notices of current literature relating to the care of cripples. There will also be listed bibliographical entries supplementary to those listed in the Bibliography of the Education and Care of Crippled Children, Douglas C. McMurtrie, which is listed below. Active work in the compilation of that volume ceased in August, 1912, and even up to that date it was necessarily incomplete. The various installments of these notes will therefore aim to keep pace with the bibliography of our subject.

Bade, Peter. Krüppelheilkunde und Rassenhygiene. Zeitschrift für Krïppelfürsorge, Hamburg and Leipzig, 1912, v, 205-212.

Biesalski, Konrad. Die Entwicklung der neueren Krüppelfürsorge. Medicinische Reform, Berlin, 1912, xx, 23-26.

Biesalski, Konrad. Modern methods of cripple care in Germany. Journal of State Medicine, London, 1912, xx, 595-604.

Browne, Blanche Van L. My work for crippled children. World's Work, Garden City, N. Y., 1913, xxvi, 77-81.

BURGER, H. Overheidszorg voor het onderwijs aan gebrekkige kinderen. Nederlandsch Tijdschrift voor Geneeskunde, Amsterdam, 1912, 2d ser., xlviii, I ${ }^{\mathrm{B}}, 1709-1712$.

Cleveland. Board of Education. Cleveland public schools: annual report of the superintendent of schools, 1911-1912. Cleveland, [1912]. 
Detroit public schools. Detroit: [Board of Education], 1911. School for crippled children, p. 51-53.

Fürstenheim. Die Seele des Krüppels. Zeitschrift für Krïppelfürsorge, Hamburg and Leipzig, 1912, v, 221-223.

Heim. Was kann von Staat und Gemeinde auf dem Gebiete der Krüppelfursorge geschehen? Zeitschrift für Krüppelfïrsorge, Hamburg and Leipzig, 1912, v, 178-184.

Institute for crippled children in Munich. Journal of the American Medical Association, Chicago, 1914, 1xii, 1489.

A note in the weekly letter from Berlin. Reprinted elsewhere in this issue.

Joyce, R. S. The industrial education of cripples. Railway Surgical Journal, Chicago, 1911-1912, xviii, 382-384.

LANGE, Fr. Wie weit kann heute die Zahl der Krüppel durch eine rechtzeitige Behandlung vermindert werden? Zeitschrift für Krïppelfürsorge, Hamburg and Leipzig, 1912, v, 151-159.

McMurtrie, Douglas C. Bibliography of the education and care of crippled children; a manual and guide to the literature relating to cripples, together with an analytical index. 1st edit., New York, 1913.

McMurtrie, Douglas C. Care of cripples. Reference Handbook of the Medical Sciences, 3d edit., New York, 1914, iii, 366-374.

McMurtrie, Douglas C. The care of crippled children in Germany. New York Medical Journal, 1914, xcix, 370-377.

McMurtrie, Douglas C. Early history of the care and treatment of cripples. Johns Hopkins Hospital Bulletin, Baltimore, 1914, xxv, 57-62.

McMurtrie, Douglas C. How Andy missed being a cripple. New York, 1914.

Reviewed in this issue of the Journal. 
No. 2 .

McMurtrie, Douglas C. The needs of crippled children in the State of Delaware. Delaware State Medical Journal, Wilmington, 1913, iv, 1-2.

McMurtrie, Douglas C. Provision for the care of cripples in Sweden and Norway. Pediatrics, Elmira and New York, 1913, xxv, 437-439.

McMurtrie, Douglas C. State care for crippled children in California. California State Journal of Medicine, Sacramento, 1913, xi, 293-294.

OrR, H. Winnett. The industrial education of the crippled and deformed. American Journal of Orthopedic Surgery, Philadelphia, 1912-1913, x, 195-200.

OrR, H. WinnetT. The relation of politics to the state care of crippled and deformed. Journal of the American Medical Association, Chicago, 1913, 1xi, 1521-1522.

Abstracted in this issue of the Journal.

Painter, Charles F. Orthopedic hospitals and vocational training for cripples. Lancet-Clinic, Cincinnati, 1913, cx, 226230 .

Philadelphia. Board of Public Education. Annual report of the Superintendent of Public Schools of the City of Philadelphia for the year ending December 31,1913. Philadelphia, 1914.

Orthopedic class, p. 29-30. This passage reprinted in this issue of the JOURNAL.

Philadelphia Orthopedic Hospital and Infirmary for Nervous Diseases. Social Service Department. First annual report. Philadelphia, 1912.

Crippled children, p. 8-9.

-. Second annual report, Philadelphia, 1913.

Class for cripples, p. 11-12. 
Rosenfeld, Leonhard. Die Krüppelfürsorge im Dienste orthopädischer Wissenschaft. Verhandlungen der deutschen Gesellschaft für orthopädische Chirurgie (Berlin, XI Kongress), Stuttgart, 1912, 415-424.

Schanz, A. Krüppelfürsorge und orthopädische Schulturnkurse. Zeitschrift für Krüppelfürsorge, Hamburg and Leipzig, 1912 , v, 65-69.

Schasse, W. Schule und Handwerksstuben des Krüppelheims in Verbindung mit der ärztlichen Tätigkeit. Berliner klinische Wochenschrift, 1912, xlix, 1378.

Strmson, Julia C. Special schools for crippled children. Journal of the Missouri State Medical Association, St. Louis, 1912-1913, ix, 228-232.

Sweeny, Mrriam Townsend. Gymnastics for crippled children. American Journal of Orthopedic Surgery, Philadelphia, Pa., 1913-1914, xi, 116-134.

Ulbrich, Martin. Die Berufswahl der Krüppel. Zeitschrift für Krïppelfïrsorge, Hamburg and Leipzig, 1912, v, 159-167.

U. S. War Department. Report of the Surgeon General, U.S. Army, to the Secretary of War, 1913. Washington, 1913. Artificial limbs and apparatus, p. 194-195.

Würtz, Hans. Das künstlerische Moment im Unterricht und in der Ausbildung der Krüppel. Zeitschrift für Krüppelfürsorge, Hamburg and Leipzig, 1912, v, 167-174. 


\title{
AMERICAN JOURNAL OF CARE FOR CRIPPLES
}

\author{
Published by the \\ Ifederation of Associations for Cripples
}

\author{
EDITED BY
}

Douglas C. McMurtrie

\section{EDITORIAL BOARD}

Gwilym G. Davis, M.D.

Charles H. Jaeger, M.D.

Hastings H. HART, LL. D.

Russell A. Hibbs, M.D.

ROBERT IV. Lovet, M. D.

Arthur J. Gillette, M.D.

H. WinNett ORR, M.D.

Konrad Biesalski, M.D.

JoHn Ridlon, M.D.

Robert JoNes, F.R.C.S.

PUBLICATION COMMITTEE

FOR THE FEDERATION

Miss Adelaide B. Baylis

Mrs. Helen K. Travers

Mrs. Henry B. Barnes

Mrs. George F. Shrady

\section{Volume I Number 3}




\section{AMERICAN JOURNAL OF CARE FOR CRIPPLES Volume I Number 3 \\ New York, September, 1914}

\section{CONTENTS}

The Copenhagen institution for cripples. Gustav MUskat . . 115

Statistics of crippled children in Germany and a summary of provision for their care. Douglas C. McMurtrie . . . 119

The railway cripple. R. S. Joyce . . . . . . . . . . . 125

Contributed Notes . . . . . . . . . . . . . . . . 129

Activities at the Massachusetts Hospital School, JoHN E. FisH.-Some cripples in mythology and legend, Douglas C. McMurtrie.

Editorial Notes . . . . . . . . . . . . . . . . . . . . .

Cripples and the war.-Federation of Associations for Cripples.Annual sale of the East Side Free School.-The Berlin institution for cripples.-Cripples in Swcden.-An editorial mention of the crippled child.-Classes for cripples in Cleveland.-Public school classes in Detroit.-Cripples' cottage discontinued.-Work at Robin's Nest.-Industrial education in the West.-Artificial limbs in U. S. Service.-Good Shepherd Home's sixth anniversary.--State care for crippled children.-Chicago Convalescent Homc.-A library on the care of cripples. - The London cripple classes.-Advanced training scholarships for cripples.-Typewriting instruction in England.Cripple schools in Liverpool.- Statistics of special classes in England. -Gymnastics for crippled children.

Published quarterly by the Federation of Associations for Cripples at 3505 Broadway, New York City. Subscription price, $\$ 3.00$ a yearly volume.

Application for entry as second-class matter at the post office at New York, N. Y., pending. 


\title{
THE COPENHAGEN INSTITUTION FOR CRIPPLES
}

\author{
Gustav Muskat, M.D.' \\ Berlin, Germany.
}

Of all institutions for cripples, the one at Copenhagen, Denmark, is most noteworthy. By reason of the number of patients received and the good accomplished, it may be considered a model institution. For thirty-five years there has been in Copenhagen a society for the relief of the crippled and paralyzed. It was founded by Pastor Knudsen. By the aid of state appropriations and voluntary contributions, there was established a central bureau to which any Danish people who are in any way crippled or paralyzed may be brought. Some of the patients go to the institution of their own accord, others are sent there by local authorities. The railroad fare is granted either free or at a nominal price. Patients who are mentally deficient or who, because of their mental condition, could not enjoy the benefits of the institution are excluded. Also those presenting distinctively surgical cases, and those with open wounds are debarred.

The institution offers orthopedic treatment of various kinds. Professor Panum gives gratis his services as director of the surgical department. Appliances and supplies are furnished to patients either free or at a nominal charge.

Different types of apparatus-from the simple leather appliance for those suffering from flat feet to the complicated kinds used by the paralytics-are made in the departments of the institution. The industrial department for the making of

\footnotetext{
'Gustay Muskat. Das Kopenhagner Krüppelheim. Deutsche medizinische Wochenschrift, Lejpzig, 1908, xxxiv, 426-427. A translation-with the omission of a few details not pertinent to American readers-of the above article. Translated and edited by Miss Dorothy Jacoby and Douglas C. McMurtrie.
} 
appliances embraces rooms for plaster work, for leather work, blacksmithing, shoemaking, and the production of braces. Miss Thora Fiedler, for many years superintendent of the institution, deserves credit for having so organized the industrial departments that every bit of apparatus required can be made on the premises. Under these circumstances, not only is the expense much less than it would otherwise be, but also many of the cripples are given an occupation. Apparatus made in the workrooms is also sold outside at reasonable prices. The receipts thus realized are applied towards the maintenance of the institution. The extent of the apparatus work may be judged from the fact that one year's output was valued at approximately $\$ 15,000$. And if these same instruments had been made outside the institution the cost would have been double this amount.

Another department which seems of the greatest importance is the one devoted to education. Industrial training in various trades is provided for patients after their limbs have been operated upon or they have been supplied with the required apparatus. The finer kinds of work are usually preferred as the patients do not usually possess great physical strength. At the time of my last visit in 1907 two teachers in the carpentry shop were instructing seventeen pupils, of whom a number were congenitally crippled in the lack of an arm or hand. There is no need of going in to details regarding crippling of the lower limbs as the trades can be prosecuted without using them. Right handed and left-handed joiners' benches offer the pupils every opportunity for the development of their talents.

One patient holds a tool between the upper and lower sections of his arm, another has fastened to his fingerless hand, by means of a strap, a round block which he uses for a hammer, a third uses a tool for a finger.

Nine crippled students were working in the wood-carving department-and with remarkable results. In the evening they receive instruction in drawing and modeling. 
After a certain period of instruction, the pupils must pass an examination by commission, just as normal trade students are required to do. The quality of the cripples' work and the way in which they succeed in later life is really surprising.

Younger children are given a regular primary school education, except that as much emphasis is attached to hand work as to language instruction and general training. Correct writing is considered of much importance.

In another department bookbinding and shoe-making are taught. Thirteen pupils were. learning these trades. In addition to the sewing work there should be mentioned, in conclusion the department for fine fancy work in which are made old Swedish laces, copied from antique patterns. Many of these laces are sold, the proceeds going towards the expense of operation.

In all, fifty young men, thirty young girls, and twenty-five children were living in the institution. They pay a small sum daily for meals, washing, and instruction. In addition the Charity Socicty makes a yearly grant towards the expense of each patient. Cripples who live in Copenhagen sleep at home, but receive their meals and instruction at the institution.

Any eligible cripple is admitted to the institution. Those who are unable to do this, and who have received no outside financial assistance for five years, are admitted free.

Since the inception of the work over 11,000 patients have been given care.

The points most worthy of imitation in the conduct of the Copenhagen institution are: first, that chronic and essentially surgical cases are excluded; second, that mentally disordered patien ts are not admitted; third, the excellent system of instruction in the institution, whereby pupils are enabled to get a good general education and to learn a trade by which they can support themselves in later years.

It would be an excellent thing if, at the establishment of new institutions for cripples, the general principles of the work at 
Copenhagen, were kept in view. If this were done not only temporary but also permanent assistance would be rendered to a large number of unfortunates. How similar institutions can be conducted in countries larger than Denmark, where the population and in consequence the number of cripples is greater, must be left to the future for solution. 


\title{
STATISTICS OF CRIPPLED CHILDREN IN GERMANY AND A SUMMARY OF PROVISION FOR THEIR CARE
}

\author{
Douglas C. McMurtrie \\ New York
}

The greatest possible aid to work in Germany has been derived from a census of crippled children made in 1906. This census is widely referred to, but its results are frequently inaccurately cited. Individual data regarding each cripple under sixteen years of age were recorded and tabulated. The results and findings have been prepared and presented by Biesalski. ${ }^{1}$ In all there were found 75,183 crippled children under the age of fifteen. In relation to the population this made an average of 14.8 crippled children under fifteen years of age to each 10,000 of population of all ages. Calculated on the basis of proportion to the total population of children within a similar age group, it is found that there were among each 10,000 children 35.73 crippled children. That is, among the juvenile population 0.36 , or nearly four-tenths of one per centum were crippled.

As the definition of cripple may vary considerably, we are fortunate in the fact that the compilers of this census made comparative classifications. A general division was made under two heads: Those not needing home care (nicht heimbedurftig) designated as $N$; and those needing home care (heimbedurftig) designated as $H$. The $N$ classification was then further sub-divided as $N o$ and $N k$, and the $H$ classification as $H t, H g$, and $H u$. These classes were defined as follows:

'Konrad Biesalski. Umfang und Art des jugendlichen Krüppeltums und der Krüppelfürsorge in Deutschland. Hamburg and Leipzig, 1909. 


\section{$N$ Classification}

No. Children having orthopedic defect. Needing treatment but not resident care.

Nk. Cripples. Provided for or supporting themselves. Needing neither treatment nor resident care.

\section{H Classification}

Ht. Cripples needing treatment and industrial education.

$H g$. Incurable cripples, incapacitated for industrial education, but needing care in a home.

$H u$. Incurable cripples requiring prolonged care and provision.

On this basis of classification the tabulation of statistics gives the following result. Figures are for the German Empire exclusive of Bavaria, Baden, and Hesse.

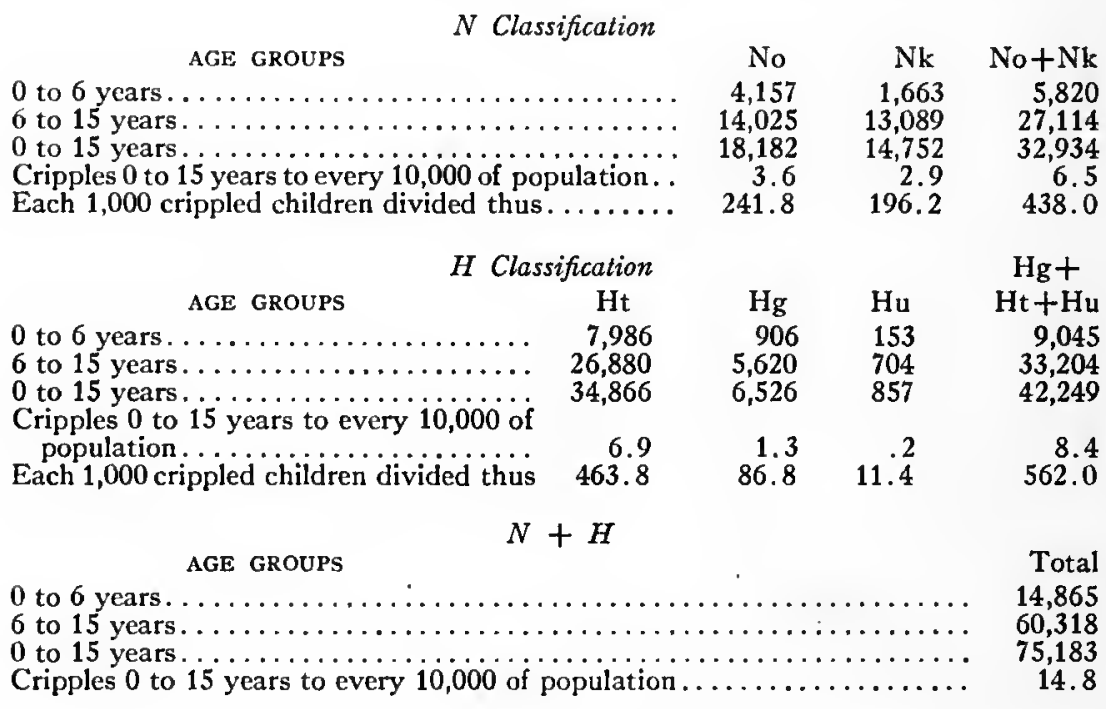

In connection with the number of crippled children needing home care, 42,249 , it was pointed out that there were available at the time (1906) in German institutions but 3,125 beds. In 
the case of 9,388 an active desire for admission to an institution had been expressed. The accommodation has since been considerably increased.

The sex distribution was as follows: Male, 39,303; female, 35,880 ; total, 75,183 . As will be seen, the distribution was a very even one. In every 1,000 crippled children there were 522.8 boys and 477.2 girls.

There has been much difference of opinion regarding the mentality of crippled children. It is not possible here to discuss this matter in detail, but the figures on mentality and character are of considerable interest.

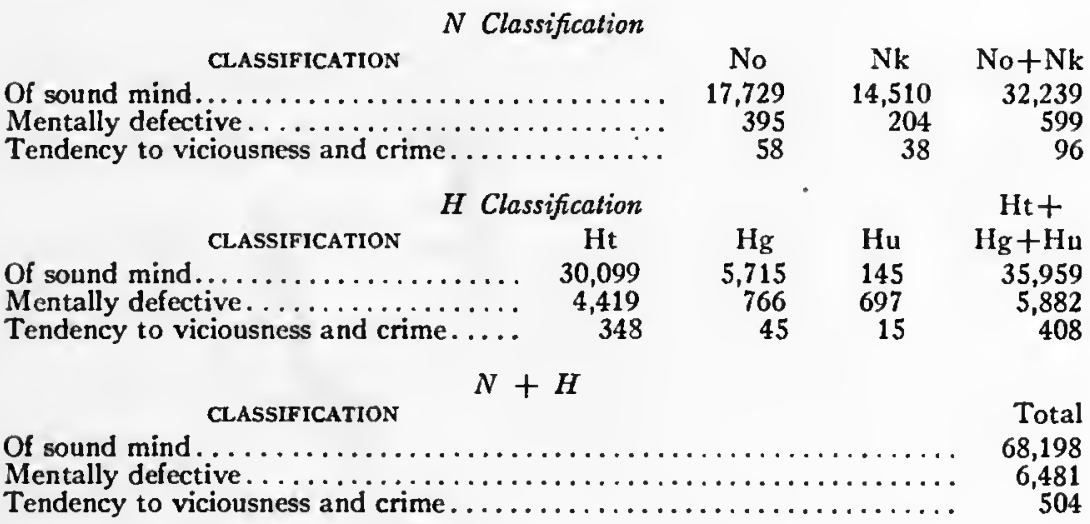

In every 1,000 the distribution was as follows, and the percentage can also be deduced:

\begin{tabular}{|c|c|c|}
\hline & In every 1,000 & Percentage \\
\hline 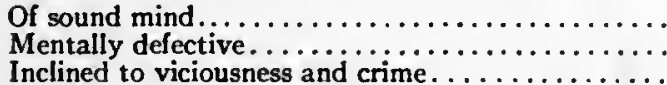 & $\begin{array}{r}885.9 \\
85.4 \\
28.7\end{array}$ & $\begin{array}{r}88.6 \\
8.5 \\
2.9\end{array}$ \\
\hline
\end{tabular}

At the end of 1910 there were in Germany fifty institutions for the care of cripples. The rate of progress was most satisfactory; the number having risen from thirty-nine two years previously. If the various institutions under a single management were counted separately and the new buildings in course of erection were also considered, there were fifty-six places in 
which care for cripples was available. Of the fifty different institutions, twenty-six were Protestant, five Roman Catholic, and nineteen undenominational. From 1908 to 1910 the accommodation capacity increased from 3,371 to 4,188 , this latter figure comprising 2,329 males and 1,859 females. The smallest home had six and the largest five hundred beds, the average being one hundred. According to religious affiliation, the Protestant homes had 2,819 beds, the Roman Catholic 425, and the undenominational 944 . The usual age of admission ranges between 14, 16, and 18 years. In twelve institutions, however, inmates as old as 36 years are received or there is no age restriction whatever.

Almost all the homes charge certain fees for care. This system, however, is designed to place part of the burden of support for the crippled child upon his or her local philanthropic or religious agencies. Thus a crippled child needing care is sent to any one of the homes and the fee paid by the public, charitable, or religious interests most intimately concerned. In the majority of instances, of course, the fee does not begin to cover the expense, the home meeting the difference through endowment or contributions. It is thought in Germany that this system of maintaining a partial local responsibility is of ultimate benefit to the cripple, especially upon returning home after the stay in the institution. The fee in the most inexpensive home is 120 marks a year; in the most expensive 1,095 marks. The average fee is 415 marks, or a little over a hundred dollars a year. There are 567 free beds and others partially so. At Angerburg all 400 beds are free. Other homes frequently decrease the fee or make no charge whatever in needy cases.

The directors of the institutions are clergymen in twenty-one cases, physicians in five, teachers in two, laymen in eleven, and sisters in six. Every home is provided with medical attendance. It will be noted how prominent is the religious element in the work. An important factor in this is the Inner Mission, a Lutheran organization, which operates several of the institu- 
tions, notably the Oberlinhaus at Nowawes, and the Samariterhaus at Cracau, near Magdeburg.

In order to gain an accurate idea of the status of educational work in the homes, it is necessary to except several of them. Four institutions are restricted to orthopedic treatment and consultation, four only have patients who are above school age and who receive advanced training, one institution which receives children only up to the age of ten has no school, and in two new homes the classes were in process of formation at the time of this enumeration. Of the remaining thirty-nine institutions, thirty-five have schools for mentally normal crippled children and fourteen have classes for the mentally defective as well. There are twelve kindergarten (often designated in Germany as Fröbel) classes and nine advanced classes.

As regards industrial training, the occupations taught are numerous. Boys are taught basket making in nineteen institutions, tailoring in eighteen, shoemaking in sixteen, brush making and chair caning in thirteen, cabinet making and bookkeeping and stenography in ten, bookbinding in seven, bandage making in six, mat weaving and key making in four, house painting, gardening, lithography, machine embroidery, the making of orthopedic apparatus, carving, wood sawing, and fret sawing in three; the making of pasteboard boxes and paper bags, agriculture, and sail making in two; drawing of architectural plans, turning, mat making, glaziers' work, the making of wooden shoes, tinsmithing, instrument making, knitting, carving, painting, mechanics, natural wood work, net making, sewing, photography, the making of portfolios, saddlery, and dentistry in one each.

The girls are taught housekeeping in twelve institutions, dressmaking and plain sewing in ten, machine knitting in nine, embroidery in eight, hand work in five, bookkeeping and stenography in four, knitting in three; weaving, cooking, and typewriting in two; basket weaving, art embroidery, Röntgen ray work, photography, machine knitting, the instruction of 
small children, lace work, chair caning, and the making of artificial flowers in one each.

Girls and boys receive instruction alike in all subjects in four institutions, in bookkeeping and stenography in fourteen institutions, in chair caning in fourteen, machine knitting in twelve, and typewriting in three.

To summarize, boys are taught forty-nine occupations and girls twenty-six. 


\title{
THE RAILWAY CRIPPLE
}

\author{
R. S. Joyce, M.D. \\ Ogden, Utah
}

If the loss of a particular member were all that entered into the make-up of a cripple, his education would be an easy matter. Men without hands or legs are seen every day earning a good living and of ten supporting a large family.

The man who begs you to let him die after the loss of one or more limbs has had most of the fight necessary in the struggle for a living taken out of him. If to this be added a prolonged hospital stay to regain ground lost through hemorrhage or prolonged suppuration, ending with poor stumps, you have the beginning of a drunkard or a shoe-string pedlar. If fellow employees have received some instruction in first aid, and the first dressing has been done under favorable conditions, two of the elements-shock and infection-which take the heart out of a strong man may often be eliminated. When the patient is out of bed in a wheel chair or on crutches, the idea of industrial training presents itself.

Men who are paid for by contract in hospitals take more kindly to cards than to work, and it is a difficult matter to compel even ordinary exercise. If litigation or other settlement is pending, stiffened joints and tendons are carefully preserved as an asset until too of ten their restoration to usefulness is impossible. If accident insurance is a consideration or there is a claim on some brotherhood for total disability, the situation is of ten worse. Add to this a desire on the part of the cripple's friends to drown his sorrows in alcohol at each appearance on the street, and one may gain a fair idea of the difficulties to be surmounted in placing in a position to earn a livelihood a man, the loss of 
whose physical members has handicapped him in this cold commercial world.

When a person has lost a hand, foot, or eye the first thing for him to get out of his mind is that he has any place on a railroad. This may look cold-blooded, but by the time he has been shunted from one department to another in search of employment, he will learn that railroads are looking for sound men, that they pay large wages for hazardous occupations, that they are held to account for the safety of the traveling public, and that they do not consider anything owing to the employee if he is accidentally injured.

Next to getting a job at flagging a crossing, comes the idea of a cigar store, but the man who has always worked for a salary has had little opportunity to acquire a knowledge of merchandizing and he too often loses what he has invested. He cannot depend on his fellow employees for trade unless he sells a better article or offers lower prices. Next to the forgetfulness of the grave comes the forgetfulness of the useless. But what is he to do? The solution of the problem lies with some genius with means - one who will, on a small scale at first, establish a training school, where without expense a trade suitable to his misfortune may be acquired. The work done in our deaf and blind institutions is a warrant for similar attempt with the crippled. If the state could be induced to admit cripples as well as deaf and blind to these institutions, a good beginning would be made.

It is surprising how well cripples get along on a farm. The use of machinery has placed almost every branch of agriculture and horticulture within his reach. But a railroad man is not a farmer; he must be taught. The idea that anyone could be a farmer may have had some foundation years ago, but to-day agriculture is conducted along scientific lines. Suppose that you had a tract of land where these men could be taught without expense. The ideal proposition would be one providing that the cripple might, at the end of a year, begin to make payments 
on a small farm or orchard which would in time become his own.

Whatever is done must be commenced before the man becomes a loafer. By reading he may begin the training before his wounds are healed, but he must be apprenticed at the moment he leaves the hospital.

Artificial limbs may be fitted to stumps, and they are useful where ordinary demands are entailed, but about moving trains there is no place for the best artificial appliance ever made.

As a rule, a man becomes a cripple suddenly. Up to that moment, his whole life has been a complete machine, but after the accident he becomes overwhelmed with a sense of helplessness. Think what it would mean for a man of education to lose an arm and then consider the hopeless abyss into which the poor uneducated laborer is plunged. But it is not so hopeless if some helping hand is extended. The railway surgeon sees these men at a time when their future course may be directed. He knows what the end-result of the injury will be, and he must be the first to start their minds along new and proper lines. All of us have seen excellent harnessmakers, teamsters, and cigarmakers without legs, and men with one arm employed in various capacities-none more successfully than on the farm, while those with short limbs and stiff joints can be taught to do almost anything if they have some instruction.

In any community outside the large cities there are not enough such cripples to form a class. They should be taught where each may see some one more helpless than himself.

While the great railways, through their 'land departments' are exploiting the agricultural possibilities of the sections they serve, I would suggest a tract devoted entirely to cripples. Let each man serve a ycar's apprenticeship and then be placed on a salary according to his worth. Let him be given, on the instalment plan, an opportunity to purchase a home for himself. This plan I have tried myself and know it to be feasible. You may see in Idaho three good farms made from sagebrush land 
within four years. On one is a man who lost a leg and on the other two the work has been done by men who had each but one arm. These men are neighbors and competitors; that is the secret of their success.

If a state school for the deaf and blind could be induced to try out a few cripples, teaching them a trade, it might be the means of getting some philanthropist to build a workshop for these unfortunates.

From time immemorial the beggar has been described as a cripple. His infirmities have been healed by every type of prayer or quackery, but he is still among us. Modern machinery has increased the number of cripples while at the same time modern surgery has made their misfortunes more bearable; but surgery, be it ever so skillful, cannot restore limbs that have been destroyed. Work of some kind will first of all restore many joints and tendons to usefulness, and second-a point even more essential-will place the cripple in a position to support himself. 


\section{CONTRIBUTED NOTES}

ACTIVITIES AT THE MASSACHUSETTS HOSPITAL SCHOOL

From the Massachusetts Hospital School at Canton two more boys with the school diploma have, during the past week, gone out to self-support, one to become assistant to a job printer, the other to take charge of the heating plant of a public building. It may be of interest to know that although the latter had double artificial legs, as soon as he completed the grades he was very ambitious to take the training given by our chief engineer. With twelve months' experience he was able to secure a fireman's license from the Examining Board of the District Police.

Moving pictures for exposition use were taken in September. Films were made of roller-skating, football, and the march to dinner.

The intermediate grades are preparing a play, for presentation in October.

The school band furnished music for the Grange Fair in this town recently. The music won much favorable attention. Pupils made exhibits of cake, embroidery, basketry, and moccasin-making. Several first, second and third ribbons were awarded by the judges.

The Mandolin Club is rehearsing in eager anticipation of the return of their teacher and the work of the new season.

The new herd of Guernscys interests the children greatly. Attended by its pupil herd-boys, it is a picturesque feature in our fields.

October 10, 1914

JOHN E. FISH. 


\section{SOME CRIPPLES IN MYTHOLOGY AND LEGEND}

Vulcan, otherwise known as Hephæstos, the god of fire, according to the mythology, was a cripple. One account holds that he was born lame and that his mother was so displeased at the sight of him that she flung him out of heaven. Other accounts say that Jupiter kicked him out for taking part with his mother in a quarrel which occurred between them. Vulcan's lameness, according to this version, was the consequence of his fall. He was a whole day falling, and at last alighted in the Island of Lemnos, which was thenceforth sacred to him. Later, however, in gratitude for his service in forging thunderbolts, Jupiter gave Venus to Vulcan. "So," remarks Bulfinch,I "the most beautiful of the goddesses became the wife of the most ill-favored of the gods."

Edipus was also a representative of the crippled and lame. "Laius, king of Thebes, was warned by an oracle that there was danger to his throne and life if his new-born son should be suffered to grow up. He therefore committed the child to the care of a herdsman, with orders to destroy him; but the herdsman, moved with pity, yet not daring to disobey, tied up the child by the feet, and left him hanging to the branch of a tree. In this condition the infant was found by a peasant, and carried him to his master and mistress, by whom he was adopted and called Edipus, or Swollen-foot." 2 Thenceforth he is described as being lame. His subsequent history is well known.

Caradoc, one of the knights of King Arthur's Round Table, became a cripple with a shrunken arm. He was found to be the son of Eliaures, an enchanter. The following recital ${ }^{3}$ tells of his affliction.

Eliaures fell under the influence of a wicked woman, who, to satisfy her pique against Caradoc, persuaded the enchanter to fasten on his

1 Thomas Bulfinch. The age of fable. Boston, 1867. p. 17.

2 Bulfinch.. Op. cit., p. 171.

¿ Thomas Bulfinch. Age of chivalry, or legends of King Arthur. Boston, 1866. p. $93-95$. 
arm a serpent, which remained there sucking at his flesh and blood, no human skill sufficing either to remove the reptile, or alleviate the torments which Caradoc endured.

Caradoc was betrothed to Guimier, ${ }^{4}$ sister to his bosom friend Cador, and daughter to the king of Cornwall. As soon as they were informed of his deplorable condition, they set out for Nantes, where Caradoc's castle was, that Guimier might attend upon him. When Caradoc heard of their coming, his first emotion was that of joy and love. But soon he began to fear that the sight of his emaciated form, and of his sufferings, would disgust Guimier; and this apprehension became so strong, that he departed secretly from Nantes, and hid himself in a hermitage. He was sought far and near by the knights of Arthur's court, and Cador made a vow never to desist from the quest till he should have found him. After long wandering, Cador discovered his friend in the hermitage, reduced almost to a skeleton, and apparently near his death. All other means of relief having already been tried in vain, Cador at last prevailed on the enchanter Eliaures to disclose the only method which could avail for his rescue. A maiden must be found, his equal in birth and beauty, and loving him better than herself, so that she would expose herself to the same torment to deliver him. Two vessels were then to be provided, the one filled with sour wine, and the other with milk. Caradoc must enter the first, so that the wine should reach his neck, and the maiden must get into the other, and, exposing her bosom upon the edge of the vessel, invite the serpent to forsake the withered flesh of his victim for this fresh and inviting food. The vessels were to be placed three feet apart, and as the serpent crossed from one to the other, a knight was to cut him in two. If he failed in his blow, Caradoc would indeed be delivered, but it would be only to see his fair champion suffering the same cruel and hopeless torment. The sequel may be easily forseen. Guimier willingly exposed herself to the perilous adventure, and Cador, with a lucky blow, killed the serpent. The arm, in which Caradoc had suffered so long, recovered its strength, but not its shape, in consequence of which he was called Caradoc Briefbras, Caradoc of the Shrunken Arm.

Douglas C. McMurtrie.

Otherwise known as Guenever. 


\section{EDITORIAL NOTES}

\section{CRIPPLES AND THE WAR}

It would be idle to discourse on the amount of physical crippling now going on in Europe. It is, of course, stupendous.

But there are other reflections suggested by the present conflict to those acquainted with provision for cripples on the continent. For instance, the one institution for the deformed in Belgium-and a most interesting and useful one-was located at Charleroi, which city, according to the daily news, was first shelled and taken by the Germans, and later shelled again and retaken by the French. It is reported that little has been left standing.

Again, plans were complete for the erection of a fine new state institution for cripples near Brussels. One can imagine its erection will be almost indefinitely deferred.

Even in England, institutions for cripples are having a struggle for existence, due to the stringent economic strain of the war, and on the continent conditions must be still worse. There are other than military aspects to such an unprofitable conflict.

\section{FEDERATION OF ASSOCIATIONS FOR CRIPPLES}

On July 1, 1914, there were 42 active cases on file with the Federation of Associations for cripples. Between that date and October 1, 65 new cases have been referred by hospitals, convents, institutions, private individuals and so forth. Of these 107 cases, 63 have been closed in the following manner.

Work obtained for,

5 No action necessary, 7

Referred to proper authorities, 9 Found work, 
Sent to hospital,

Sent to country,

Already provided for,

Trade school,

Discharged,

Sent to school,
2 Obtained glasses for,

13 Moved-could not be traced, 3

10 Sent home to Key West, 1

4 Scholarship at college, 1

1 Treatment at dispensary, 2 1

1

Total, $\quad \overline{63}$

On the remaining 44 cases some action has been taken, but with no definite results as yet:

To have treatment, Want work, For Institutional care,
7 To go to school,

19 To go to trade school, 7

4 Shut-in cases, 2

Total,

Since July 1, 1914, 2,100 record cards have been distributed, which added to those previously sent out makes a total of 4,159 . Of these, 987 have been returned and filed ready for reference. Twenty-two cards that were returned proved to be Federation cases, and are filed as such.

During the summer, the Executive Secretary visited various institutions when opportunity offered.

P. B., boy, 11 years, case of t. b. knee. Referred to Federation for an outing by P. S. 30. Arrangements were made to send the boy to Bartow, the summer home of the Day Home and School. On the day that he was to go, the secretary discovered that his knee was discharging. She advised an examination at the Post-Graduate Hospital. The boy went to the orthopedic clinic, was admitted to the hospital and operated upon. He has now returned to his home, and his mother reports that the leg is straight and the boy much stronger.

E. B., male, 34 years, case of paralysis. Referred to the Federation, for work, by the Shut-In Society. On investigation, the secretary found that the man was not strong enough to take any outside work, but wanted something at home. Application was made to the owner 
of the house in which he lived to have it licensed. The secretary was authorized to secure it in the owner's name, which was done, and the card together with a list of firms giving out their work sent to $\mathrm{Mr}$. B.

U. C., boy, 5 years, case of infantile paralysis. Referred to the Federation, for admission to school, by the Union Settlement. The secretary called at the boy's home and saw his mother. Arrangements were made for U. to enter the Rhinelander School. The school 'bus called for him two days later.

E. L., boy, 19 years, case of amputated arm. Referred by the Children's Aid Society. Wanted work in order to pay his debt to the Children's Aid Lodging House before attempting to work his way back to Key West, his home. On consultation, it was decided that it would be better for the boy to leave New York at once, and send back the money when he could earn it. Impossible for him to work his way, but a steerage passage was given to him through the kindness of the president of the Mallory Steamship Line, and E. writes that he has started to work, and will pay his debt at the earliest possible moment.

D. T., boy, 19 years, case of infantile paralysis. Came into the Federation office trying to sell photographic material. The secretary talked with the boy and found him very ambitious. Had finished grammar school at 14, entered De Witt Clinton High School, at the same time taking the course in architecture at Cooper Union. Having graduated from both of these, was very anxious to continue his studies. Application was made to New York University and a scholarship granted for the year. Money for extra expenses was obtained, and D. is now attending college, at the same time doing outside work on Saturdays to help pay for his books, instruments, etc.

A. V., female, 24 years, case of infantile paralysis. Referred by East Side House. Wanted scamstress work. Badly crippled, but could sew very well. The secretary made personal application to a dressmaker, who took the girl for a few weeks in the spring. In the autumn, application was made to another dressmaker, who took A. on trial, and is still keeping her.

M. A. and J. A., sister and brother, $31 / 2$ and $41 / 2$ years. Cannot walk. Referred by nurse at the Union Settlement. Secretary called and found the children in a badly under-nourished condition. Mother 
not at all well. The boy of $4 \frac{1}{2}$ was admitted to the Babies' Hospital, and the mother and little girl sent to the country.

A. W., male, 24 years, case of paralysis. Social service worker at Randall's Island consulted the Federation about the possible disposition of the boy after his dismissal from the Island. The Trade School of the Hospital of Hope was suggested, application made, and the boy admitted.

ANNUAL SALE OF THE EAST SIDE FREE SCHOOL

The Crippled Children's East Side Free School, at 157 Henry Street, New York City, has maintained for the past ten years a workroom for older cripples, where orders have been filled for all kinds of needlework from the finest embroidery to the simple hemming of towels. The workers are paid a weekly wage, depending on their earning capacity. Expert teaching is provided, so that those who are handicapped can be trained to the highest point of efficiency possible.

An exhibition and sale has been held each year, not only for the purpose of disposing of the workroom output, but in order to bring the work to the attention of those likely to be interested in this form of welfare work.

This year's sale will take place on Tuesday afternoon, December 8, at Delmonico's, Fifth Avenue, and 44th Street, and all who have any interest in the industrial possibilities for cripples are urgently invited to come. Members of the Board of Directors will be in attendance and will gladly furnish information as to details.

\section{THE BERLIN INSTITUTION FOR CRIPPLES}

The following description ${ }^{1}$ gives a very good idea of the work during the last few years of the extensive institution for cripples in Berlin, the 'Berlin-Brandenburgische Kruppel-Heil- und Erziehungsanstalt,' presided over by Dr. Konrad Biesalski,

1 The Berlin-Brandenburg Cripple Hospital and Training College. Journal of State Medicine, London, 1912, xx. 573-574. 
the editor of the German periodical dealing with the care of cripples, the Zeitschrift für Krüppelfürsorge.

Since November, 1907, the institution has been accommodated in what used to be a municipal training home, situated on the grounds of the Municipal Hospital Am Urban, on the site Am Urban, 10, 11.

The staff comprises the following members: A medical superintendenit, four medical assistants, one administrative manager, two schoolmasters, one mistress for teaching handwork, and one mistress for physical exercises. There are also two medical supernumerary workers.

In addition to the above there is a staff of nurses with a lady superintendent at the head; most of the nurses are recruited from the welleducated classes and have received their training at the institution.

The number of inmates is at present 135, and the actual institutional work is divided into three sections: (1) a clinical section; (2) an educational section; and (3) a workshop section.

In 1909 an Out-patient Department was added.

The Clinical Section includes an aseptic operating theatre with the requisite accessory rooms, a Röntgen department, the 'Medicomechanical' hall, the clinical laboratory, the library, a collection of anatomical preparations, and last, but by no means least, the orthopædic workshop; in the last three, skilled workmen and four apprentices work under the direction of a master.

The Educational Department is adapted as much as possible to the special and variable needs of the pupils. In place of the ordinary school curriculum the teaching is arranged on the lines of a work school in which mainly handwork is taught, and in which the acquirement of manual dexterity ensures the necessary degree of discipline.

This preliminary training is completed in the actual Workshop Section, where the entire teaching aims at producing skilled efficiency. In suitable cases theoretical instruction is imparted at the bedside, never more than thirty minutes at a time.

The educational course is divided into three classes, with a supplementary class for mentally backward children.

As a special feature of the training, the children are grouped into Genossenschaften (guilds) which centre on music, drama, literature, and so on. 
The workshops are under the direction of fully trained instructors, in addition to a crafts mistress, a nursing sister, and two scwing mistresses.

In the workshops the male pupils are taught the following trades: Shoemaking, tailoring, basket making, orthopædic mechanics, the making of artificial limbs, surgical appliances, etc., dental mechanics, clerical office work, and skilled laundry work.

The girls are taught commercial practice, clerical office work, weaving, art needlework, Röntgen technique, photography, machine embroidery, plain sewing and tailoring.

All the pupils attend graduated continuation classes in which four hours' instruction is given weekly.

The Out-patient Department was instituted to meet the urgent necessity for extending further care and treatment to discharged patients. It also fulfils an important function in acting as an expert authority which can give physical certificates relating to the working capacity of cripples who are not in need of residential treatment or who are not suitable cases for admission; its activities under this head are largely increasing. When necessary, such cases are also admitted on the list of out-patients.

The present building is only a provisional home. A large donation, called the 'Oskar Pintsch Fund for the Promotion of Cripple Care' has rendered it possible to build a home large enough to accommodate 250 to 300 children, and replete with every scientific modern requirement, on an extensive forest plot in the Grunewald.

The new buildings were commenced in August, 1912, and are now being occupied.

Another note on the work of the institution and its status in 1910, appeared in a recent article 2 . It reads as follows :

Berlin-Brandenburg Krüppel-Hcil- und Erziehungsanstalt, Berlin. Undenominational; founded 1906. It accommodates one hundred and thirty from infancy to sixteen years of age, at a daily expense of two and a half marks for clinical cases, others paying 500 marks annually. There are five free patients. Beside the director, there are twentyseven sisters and seventeen servants. The institute has three classes,

2 Douglas C. McMurtrie. The care of crippled children in Germany. New York Medical Journal, 1914, xcix, 370-377. 
with a master, two teachers, one kindergarten, one class for abnormal pupils, and three advanced classes. Separate religious instruction is given Protestant, Roman Catholic, and Jewish inmates. The boys are taught shoemaking, tailoring, basket weaving, bandage making, making of orthopedic apparatus, office work, dentistry, and machine knitting; the girls dressmaking, housework, weaving, plain sewing, art embroidery, photography, Röntgen work, and commercial operations.

\section{CRIPPLES IN SWEDEN}

Dr. Th. Resmark writes the editor from Stockholm that Sweden is full of cripples from infantile paralysis, the numbers taxing their facilities to the utmost. The situation is aggravated by the fact that the modern hospitals are organized for the reception of acute cases only, and patients who require prolonged treatment are necessarily rejected. The only resort is to the special institutions for cripples.

\section{AN EDITORIAL MENTION OF THE CRIPPLED CHILD}

It is seldom that the needs of the cripple are mentioned in publications of general circulation. It is, therefore, of especial interest to see the matter brought up in the editorial columns of so widely read a periodical as the Youth's Companion. The article $^{3}$ in question, which is exceedingly well-advised in character, is quoted herewith in full:

All mothers, and most teachers and employers who have to do with crippled persons know how difficult it is to deal with them. People who try to find work for them discover that openings that they can fill are extremely rare, for even when employment can be found for the boy who is in some way incapacitated it frequently happens that he fails to keep the place, not so much because of his physical incompetence as on account of his temperamental infirmities.

In Boston, Miss Grace Harper, of the King's Chapel Committee for the Handicapped, has made a special study of the subject. She finds that the average cripple is at a disadvantage because he has

'The crippled child (Editorial). Youth's Companion, Boston, 1914, lxxxviii, 506. 
been so pampered that his strength of character has deteriorated. The mental effect of never being crossed and always being coddled is as bad for the small boy who has only one leg as it is for the small boy who has two legs, but nine persons out of ten never think of it.

Many deformed persons are quite able to learn a trade and to earn their living at it, and it is necessary for some of them to do so; but there are many of them who cannot hold a place because they have not grasped the first principle of getting along with fellow workers. They have been over indulged at home, favored at school and spoiled by the community, from the instinctive desire that we all feel to make it up to them.

The time may come when the parents can no longer support the little daughter who can sew but cannot walk, or the son who can use his right hand but not his left. The future of that child will then depend upon his character and training, as the future of every child does; yet it is preciscly those who need character and training most of all that through mistaken kindness are most of ten prevented from obtaining either.

Miss Harper maintains that the physically handicapped should be treated primarily not as unfortunates, but as reasonable beings. One reason why New York sends its crippled children to the general public schools instead of to special schools is that they may learn the ways and requirements of other children. Our compassion for the child who has a crippled body should not so blind us to his future as to allow us to cripple his will power too. Wise discipline is needed to enable him to compete with normal children on as even terms as possible.

\section{CLASSES FOR CRIPPLES IN CLEVELAND}

In the report of the Superintendent of Schools, Cleveland, Ohio, appears the following statement $t^{4}$ regarding classes for crippled children.

The instruction of crippled children was cared for by the Board of Education in co-operation with a charitable organization known as the Sunbeam Circle, which had supported this school until it was

- Cleveland public schools: annual report of the superintendent of schools, 1911-I9I2. Cleveland, [1912]. 
taken over by the Board. A building for these children was erected in the yard of the Wilson School. Originally the corps of instructors consisted of a principal, two grade teachers and a kindergartner; this year another room was added to the building and an additional teacher will be needed. The enrollment numbered ninety-five of more or less helpless children. The expense of transportation and of the noon-day luncheon was borne by the Sunbeam Circle. Four omnibusses made their daily round, conveying the children from all quarters of the city to the school and in the afternoon safely took them home again. The school session continues from $9 \mathrm{a} . \mathrm{m}$. to $2.30 \mathrm{p}$. m. with a break at 11.30 a. $\mathrm{m}$. for luncheon. The children are served a hot and nourishing meal, especially adapted to their needs, for many of them are underfed and some sub-normal, and in addition have had a long ride to reach school and must take the same on the return trip. The luncheon is served by three young girl helpers, whom it is very necessary to have in the school to assist the more helpless children.

In addition to such ordinary school work as the children need and are able to take, there is hand training in connection with drawing and number work, and classes in clay modeling and raffia weaving. It is the intention to give manual training to those who can take it. The children are entertained with books and pictures. The favorite game at recess is playing horse.

A nurse from Lakeside Hospital was in daily attendance and also a man to lift and carry such children as needed assistance.

At Holy Cross House, a small hospital for crippled children, one teacher during the year gave class or individual instruction as circumstances permitted. The number of pupils varied but the average was about 10 .

\section{PUBLIC SCHOOL CLASSES IN DETROIT}

Provision for crippled children is made in the public school system of Detroit, Mich. The work is mentioned ${ }^{5}$ in a pamphlet descriptive of the schools of the city, issued several years ago. As the material is of considerable interest it is quoted herewith.

Every child is entitled to all the education which the state can give him. Acting upon this principle, the Board of Education in January,

\footnotetext{
B Detroit public schools. Detroit: [Board of Education], 1911, p. 51-53.
} 
1910, organized the School for Crippled Children. Free transportation was provided by the Board of Education for 16 children, and a room was set aside for their use in the Harris School. A teacher was placed in charge to give individual instruction to pupils whose ages ranged from 6 to 14 years. In September, 1910, the school was transferred to the Clinton School building, the lower floor of which had been remodeled for the use of these little ones. An outside elevator had been added, and a kitchen, a dining room, rest rooms and toilet rooms provided. Two classrooms were opened instead of one, as the school had an average number of 25 belonging during the entire year, with a total enrollment of 66 .

When the work was organized only half-day sessions were held, but in November, 1910, an innovation was introduced in the form of a warm, hearty luncheon at noon. By this arrangement the children can remain all day at school. After the luncheon is over the pupils have a half hour's recreation period and then are placed in reclining chairs to have a half hour's quiet rest before the afternoon session begins. In addition to the noon luncheon, milk and biscuits are served at 10 o'clock each day. The progress made by most of the members of the school is most gratifying. They are so eager to learn, so happy in the thought that an opportunity is given them to learn as other boys and girls do, that their progress is greatly facilitated.

In this school, as in the special rooms, an attempt is made to give special training in handwork. A course in applied design is being worked out for the older children by the Assistant Director of Drawing, and already good results have been obtained. For the younger children special attention is given to weaving and cutting, calling for the training of the hand and eye.

In addition to the teachers, a nurse is provided to care for the pupils, many of whom are practically helpless, and to prepare the noon luncheon, serve the milk and assist the pupils to and from the carriages. Does all this expense pay? Visit the school and see the happiness of these little 'shut-ins,' whose horizon-until this school was provided for them-was in most cases the four walls of their homes or the outlook from their own doorsteps. Many have improved in health since they have had these long rides to and from school, together with a change of food and environment. The added cost to the city now will be more than made up in later years when many of the 
boys and girls, instead of being helpless charges, shall have become self-supporting citizens, largely as a result of the training and education given them in the School for Crippled Children.

As regards transportation, carriages to take the children to and from school are provided by the Board of Education at an expense of about twenty-five dollars a day.

\section{CRIPPLES' COTTAGE DISCONTINUED}

Several years ago, there was started a cottage for cripples at the State Orphans' Home, Atchison, Kansas. According to recent advices, however, this has been discontinued, the building being now used for other purposes. Only normal children are received at the institution.

\section{WORK AT ROBIN'S NEST}

The twenty-third annual report of Robin's Nest, Tarrytown, $N$. Y., covers the work of that summer convalescent home for crippled children during the season of 1913. The institution was founded in 1891 and incorporated in 1901. A short statement of last year's work reads as follows: "Twenty-two girls arrived from the Hospital on May 15, and after their departure two months later, their places were filled by a like number of boys who, with the exception of a few changes, remained until the Nest closed on November first. Every child gained in weight and returned to the Hospital showing substantial improvement in every way, as a result of the summer's outing."

\section{INDUSTRIAL EDUCATION IN THE WEST}

An interesting discussion ${ }^{6}$ of some of the problems of industrial training for cripples by Dr. H. Winnett Orr recently appeared in a western journal. It is reprinted herewith.

There is a growing tendency on the part of those who are engaged in public as well as private philanthropy to direct their efforts toward

- H. Winnetr ORR. The industrial education of the crippled and deformed. Western Medical Review, Omaha, Neb., 1912, xvii, 241-243. 
the prevention of dependency, rather than simply provide care for those who become dependent. This tendency finds expression in many ways which are comparatively new. To some of us, at least, none of the newer ways of providing against dependency is more interesting or more profitable than the correction of deformity in children or the proper care of those prospective cripples suffering from chronic disease. A surprisingly large number of such patients, especially if cared for during childhood, may be converted from helplessness to a state of complete or comparative independence.

Those of us who have been engaged for some years in the hospital care of these children, however, are having it forced upon us that hospital care alone is not sufficient to establish the permanent independence of such individuals. A considerable number of our orthopedic patients are, by reason of the nature of their disabilities, unable to avail themselves of the ordinary opportunities for acquiring an education. It is not uncommon, therefore, for such patients at the completion of their hospital care to find themselves several years behind normal children of the same age in the matter of their school work. Not only this, but many of these patients even at the completion of hospital care and when all has been done for them that can be done, find themselves physically unequal to the performance of all the duties of any given trade or occupation. The mere statement of the problem suggests the answer, which is that such children during their hospital care and afterwards should be carried along by means of special methods of instruction, so that when the hospital care has been completed they may, as rapidly as possible, be provided with such an education as will enable them, no matter what their condition, to perform some duties by which they can earn a livelihood.

A number of industrial training schools have already been established, but a very small percentage indeed of such patients can now be cared for with the educational facilities that are available. For example, the Widener Memorial School at Philadelphia, which is one of the finest examples in the world of the form of philanthropy which I have suggested, has a million dollar plant, but limits itself to the care of less than two hundred children. All of these children in the Widener School, however crippled or deformed, are being given the best of hospital care and provided with such instruction as will render them absolutely independent. This agency is, therefore, doing 
a tremendous amount of good and doing it in as nearly an ideal manner as possible. It can readily be seen, however, that many more such agencies, even if they must be carried on at less expense of money, must be provided for such individuals.

The Nebraska Orthopedic Hospital has made a beginning in this direction; but only a beginning. All of our children, both those who are up and the bed patients who are able to do so, recite daily to competent teachers in lessons which correspond as nearly as possible to those which children of the same age are having in the grade schools. Cooking, sewing, and bookbinding are also being taught to those who are able to do those kinds of work. Other courses of instruction contemplated at the present time are horticulture, picture framing, and photography. Two of the older girls, formerly patients in our hospital, are already independent; one is a seamstress and the other a telephone operator.

It is quite important for the institution which provides hospital care to supervise the launching of these patients in occupations which will make them independent. There is a great danger that such patients if returned to their homes, either because of lack of means or because of over-sympathy on the part of parents or friends, even though much improved as to their physical condition, will relapse into a state of dependency. Constant stimulation and intelligent supervision are necessary with these children as with others to have them use such energy and ability as they have toward proper ends. Teachers and equipment must be provided in increasing measure to supplement our hospital work if a full realization is to be obtained of the plan to make these patients independent.

The State of Nebraska has been making rapid progress along the lines of caring for its orthopedic patients and by doing just a little more our institution will stand in the very forefront of those which are being devoted to work of this particular kind.

\section{ARTIFICIAL LIMBS IN U. S. SERVICE}

Any officer, enlisted, or hired man in the military or naval service of the United States who has lost a limb, or the use of a limb, from injury incurred in the line of duty, is entitled to receive from the Government once every three years an artificial 
limb, or apparatus, or commutation therefor. The commutation in case of amputation of a leg is $\$ 75$. In cases of loss of an arm or the loss of the use of an arm or leg, the commutation allowed is $\$ 50$ in each case. Pensioners desiring artificial limbs instead of commutation are allowed transportation to and from the place of business of the nearest authorized manufacturer of artificial limbs.

The laws relating to artificial limbs are the Revised Statutes, Sections 4787 to 4791 , and the Acts of August 15, 1876, and March 3, 1891.

The annual report of the Surgeon-General of the Army gives the following statemen $t^{7}$ regarding this provision:

Under laws relating to artificial limbs and apparatus, or commutation therefor, orders on manufacturers were given during the fiscal year for 17 legs and $\mathrm{I}$ foot. Commutation certificates were issued for I 55 cases of amputated leg, 92 of amputated arm, 7 of amputated foot, and 1,667 cases of loss of use of limb.

Under the act of June 17,1870 , and subsequent amendments thereto, 23,583 disabled soldiers and sailors have been furnished artificial limbs or apparatus, or have received commutation in money since the passage of the act, as follows: Total number benefited to June 30, 1913, 23.583; died, 14,236; dropped from rolls, 592; rejected after one or more payments, $57 \mathrm{r}$; remaining on rolls at end of fiscal year, 8,192 , being a loss of $32 \mathrm{I}$ beneficiaries during the year.

Two-thirds of the periodical claims for benefits under the artificiallimb laws for the three years ending June 30, 1917, become due in the fiscal year 1915. To meet these claims it is estimated that the sum of $\$ 275,000$ will be required.

\section{GOOD SHEPHERD HOME'S SIXTH ANNIVERSARY}

The Good Shepherd Home, of Allentown, Pa., celebrated its sixth anniversary on August 6 and issued a programme ${ }^{8}$ of the

${ }^{7}$ U.S. War Department. Report of the Surgeon General, U. S. Army, to the Secretary of War, 1913. Washington, 1913, p. 194-195.

Sixth anniversary of the Good Shepherd Home. Allentown, Pa., 1914. 
occasion. This institution has several objects, one of which is the care of crippled orphans. The programme mentioned gives pictures of the buildings making up the home and also of some of the residents. In a short historical sketch appended it is stated that the institution had its inception in "the humble building of the rented parsonage of Grace Lutheran Mission, Allentown, Pa., with a crippled orphan as the first inmate. This took place on the 21st of February, 1908, or on the one hundredth anniversary of the birth of one of the fathers of Inner Mission Work, William Loehe, of blessed memory." The first building was acquired on February, 25, 1908, and since then four others have been added. The Home now owns property valued at $\$ 55,000$, against which there is a debt of $\$ 22,500$. The particular classes of beneficiaries received are as follows: crippled orphans, blind orphans, infant orphans, destitute children, old people, and aged or disabled ministers.

\section{STATE CARE OF CRIPPLED CHILDREN}

An argument setting forth the advantages of and the need for state care of crippled children has recently been presented ${ }^{9}$ by Dr. Wallace Blanchard, the conclusions being based on his long experience in the work of the Home for Destitute Crippled Children, Chicago, Ill. The public economy effected is first discussed.

It has been declared in the legislatures of the three states of New York, Minnesota and Nebraska that it costs much less to correct the deformity of a destitute crippled child and make it a future selfsupporting and up-building factor in the state than to leave it to be a public beggar, or to remain in some other way a burden upon the people of the state for its natural lifetime. Acting upon this policy, which it may be assumed is well proven, the above-named states have established state orthopedic hospitals, with orthopedic surgeons of good reputations in charge.

${ }^{9}$ Wallace Blanchard. The state care of crippled children. Chicago Medical Recorder, 1914, xxxvi, 162-167. 
There are then described some of the cures effected under the improved modern methods of orthopedic treatment. The possibilities of work for cripples are thus demonstrated in a practical manner. The work of the Chicago institution and the suggestion for further extension under state aid is set forth as follows:

The Home is sustained as a charity institution by the contributions of the 'Home Society,' which is composed of two hundred nobly generous men and women under the presidency of Mr. Charles G. Dawes. The institution is the only strictly orthopedic hospital in Illinois, and it has 105 beds, full all the time. Mrs. R. H. McElwee was the kind donor of the Nancy McElwee Memorial out-department building, which is filled nearly every afternoon with little cripples in arms that are treated there and cared for at home. Mrs. McElwee also donated the roof garden for tubercular bone cases. The Clara L. Dixon Memorial Building, which is the nurses' home for the institution, was the generous gift of Mr. Arthur Dixon. The orthopedic surgeons and general medical staff hold their appointments from Rush Medical College, and their services are given entirely free.

With the greatest economy in handling the funds, it costs ninety-five cents a day for each child, or about thirty thousand dollars a year to sustain the Home. During my twenty years of service on the orthopedic staff I have seldom met a member of the Board of Trustees with out hearing how dubious was the prospect of raising the two or three thousand dollars necessary for the care of the one hundred occupants of the little white beds at the Home for the coming month.

This is a work that is being done by a few charitable individuals for the people of Illinois, and the state should at least help to carry the financial burden. Members of the legislature are now making a move toward giving state assistance to The Home for Destitute Crippled Children, and I hope that I have presented the work and financial exigencies so clearly that every Illinois reader will feel impelled to write to the member of the legislature from his district, asking him to speak and vote for a fair appropriation for this institution.

It appears that the City of Chicago gives the institution annually three thousand dollars in consideration of its assuming 
charge of all crippled children assigned to it by the Juvenile Court, but the grant usually falls short of the actual expenses on the cases concerned.

\section{CHICAGO CONVALESCENT HOME}

Supplementing the work of the institution just described is a country home' ${ }^{10}$ now known as the 'Country Home for Convalescent Children,' but formerly as the 'Convalescent Home for Destitute Crippled Children.' It is located at Prince Crossing, Ill., twenty-five miles west of Chicago. The buildings stand on a wooded hill in the center of a 96-acre farm. The institution opened on July 10, 1911.

Provision is made for primary instruction in addition to training in needlework, housework and farm work.

The institution in its entirety stands free from debt and has already a considerable endowment. A full description of the work and equipment of this complete establishment will appear in an early issue of the JourNaL.

\section{A LIBRARY ON THE CARE OF CRIPPLES}

The editor of this Journal has, during the past five years, endeavored to collect as much printed material as possible bearing on the care of cripples, with the aim of building up in time an adequate library on the subject. The effort has seemed to him important for several reasons. In the first place such a collection is essential in the actual work of editing a publication which shall provide accurate information regarding the history and present activity of institutions for cripples. Second-and upon this point should be placed far greater emphasis-the subject of care for cripples has been practically neglected by the large libraries which ordinarily preserve the literature on any special department of work. In the future, if the care of cripples attains a position of magnitude and importance-as we

${ }^{10}$ Country Home for Convalescent Children. Prince Crossing, Ill. [Descriptive booklet.] 
all expect it will-a comparatively complete library would be of inestimable value. As a matter of fact, it would have been desirable had some collection been started many years ago, since many of the early publications are not now to be obtained. As it is, every present opportunity should be improved.

The collection in question, now being gathered by the editor, is fairly rich in publications from foreign sources-files of reports from Germany, England, Denmark and other countries, monographs, official documents, periodical articles, reprints, and books. A good beginning has been made on American material, and in this field the collection should be, and can be made, especially complete. At the present time, however, the files of publications of some American institutions are scantier than those of many foreign organizations.

The object of this note is to explain the effort and ask the co-operation of the various persons and organizations concerned in the care of cripples. Reprints, magazinc articles, and booklets are requested, but what is most urgently desired is a full file of the annual reports of each institution, or-this not being available-as complete a file as possible. During the next week there will be sent to each institution a list of their publications already obtained with a request to supply as many as practicable of those lacking. It is hoped that this request will mect with a satisfactory response and that many of the older documents will be brought to light.

The editor agrees on his part to have all the material classified, indexed, bound, and made available for necessary use. Already the books, miscellaneous pamphlets and articles, and many of the foreign reports have been bound up in durable library bindings and are now being indexed. The binding of the American material will be deferred pending the replies to the present appeal. Then, at as early a date as possible, there will be published an index-catalogue to the collection, which should also prove a useful bibliography of official publications relating 
to cripples. Already the collection comprises over a thousand items.

This detailed statement of the circumstances is made in order that the requests to be sent out may not be considered idle, but as having a deliuite purpose in view. It is earnestly hoped that the response may prove rich in results, and that erentually the collection may be of value to all concerned.

\section{THE L.ONDON CRIPPLE CLASSES}

A general statement regarding the provision for crippled children in the London public schools has been sent the JourNaL by the Education Ofticer of the London County Council under date of August 4, 1914. It is entitled 'London County' Council Schools for Physically Defective Children.' The text is given below. It will be noted that over three thousand crippled children are being educated in the London school systen.

Provision is male by the Council for the education and training in special schools of children certified as physically defective under the Elementary Education (Defective and Epileptic Children) Act, 1899.

The Conncil maintains 40 day schools for the physically defective (inclueling a school for tuberculous children) with a total accommodation of 3,373 places. The Council has not provided any residential school for the physically defective. Arrangements have, however, been made by which not exceeding 24 physically defective boys and girls are received at the Heritage School of Arts and Crafts at Chailey in Susex. The children sent to this schoul are specially selected as being likely to receive bencfit by the change and to profit by the instruction given at the school.

Schools for the physically defective provide for the education of childrell who suffer from serious and detinite ailments of long standing which may be curable or incurable, but are such as to preclude attendance at an ordinary school, the children being nerertheless educable under suitable conditions.

The curriculum is devised to meet the special physical conditions of the child and the 'backwardness' due to prolonged absence from school. It includes a modified scheme of elementary training to 
which are added art and craft training and manual and inclustrial occupations. In the schools which have been more recently erected, woodwork rooms are being set apart for boys. Cookery instruction is also given to specially selected girls. The hours of instruction in the Council's schools are from 9.30 to 12 and from 1.30 to 3 .

Some difficulty is experienced in organizing the schools for physically defective children, as on accomt of the small numbers in attendance a child may have to spend two or three years in the highest class. It has accordingly been arranged for further instruction to be provided to those elder children who are found fit to receive trade instruction. To meet these requirements in the case of girls the Council has established as an experiment two schools for elder physically defective girls between the ages of 12 and 16 years at New ling's Road, Fulham, and Holland Street, Brixton. The subjects of instruction at the New King's Road School are English, Drawing, Dressmaking, Blousemaking and Embroiclery and Needlework, and at the Holland Street School, English, Drawing, Fine Necdlework and Embroidery, and the making of children's garments. Consultative committees of trade experts have been appointed to advise as to the instruction given in each school. The experiment appears to be working satisfactorily, some of the pupils having obtained, as a result of the training received at the schools, suitable situations with firms in the trades in which they have been instrueted.

The Council has for some time past been carrying on schools in three hospital premises, viz., the Royal National Orthopadic Hospital (Marylebone), the Hospital and Home for Incurables (Hampstead), and the Alexandra Hospital (Holborn). The classes are conducted in the wards of the hospitals.

The Council has entered into an agreement with the Committee of the Paddington Tuberculous Dispensary for carrying on as an experiment a school for children suffering from incipient phthisis or with the disease in a definite form. The Council has agreed to provide the staff and school materials to enable the school to be carried on, and the Dispensary is responsible for the provision and maintenance of the premises, furniture and nursing staff. The sehool is under the constant supervision of the Medical Officer of the Dispensary.

The Council has 55 ambulances in use for conveying children to its schools for the physically defective and 42 omnibuses are hired to 
assist in this work. A motor ambulance will shortly be put into use.

The After Care Committec for Blind, Deaf and Crippled Children is continuing to perform most valuable work in securing employment for, and in keeping records of, children who have left these schools. In any case in which the parents require assistance in placing a child they make application to the Committec who deals with the case after receiving the report of the School Medical Officer as to the child's capabilities.

\section{ADVANCED TRAINING SCHOLARSHIPS.FOR CRIPPLES}

The provision for the education of crippled children in the English public schools is of elementary grade only. In order, however, to provide further training for deserving crippled scholars who seem likely to benefit thereby, the London County Council offers a certain number of 'cripple scholarships,' these covering the cost of advanced instruction in various educational institutions. For instance, some holders of these scholarships are sent to a special trade school for cripples in Chailey, Sussex.

In 1913 the Council awarded ${ }^{11}$ ten such scholarships to crippled children, in five cases to be tenable at trade schools.

\section{TYPEWRITING INSTRUCTION IN ENGLAND}

In the London public schools there are conducted special classes for crippled children,- physically defective children, as they are officially termed. Provision has but recently been made for the introduction of typewriting instruction in these classes. In one of the reports of the Education Committee to the London County Council appears ${ }^{12}$ the following note on the subject:

We have had under consideration the question of including instruction in typewriting in the curriculum of the Council's schools for the physically defective. We are of opinion that a knowledge of typewrit-

${ }^{11}$ London County Council. Minutes of proceedings, January to June, 1913. London, n. d., p. 1308.

${ }^{12}$ London County Council. Minutes of proceedings, January to June, 1913. London, n. d., p. 322 . 
ing would be most helpful in securing employment for many of the elder children on leaving school, and we suggest that this subject should be included in the scheme of work. In the majority of the schools there are members of the staff who are either able to give the necessary instruction, or are willing to qualify themselves to give it. The only expenditure involved is, therefore, the cost of the typewriters, which will amount to approximately $£ 100$.

The necessary financial provision was made by the appropriation $^{13}$ of the sum named, equivalent to about five hundred dollars, to be available for use during the school year of 1913-1914.

\section{CRIPPLE SCHOOLS IN LIVERPOOL}

During the calendar year 1913, the usual provision was made for crippled children in the public schools of Liverpool, England, according to the report ${ }^{14}$ of the medical officer for the special schools to the Education Committee. During the year 181 children were passed for admission to the classes for the 'physically defective.' As stated in the report: "Four schools provide accommodation, in separate sections, for both mentally and physically defective children; one school accommodates mentally defectives only, and the remaining one physically defectives only. This latter school is carried on in connection with the West Kirby Children's Convalescent Home." There are these five centres where educational facilities for cripples are provided.

The accommodation of these classes during the year was 434 , the number on the rolls 523 , and the average attendance 436.

But in addition to this regular work the Liverpool Education Committee has shown itself especially progressive in the inauguration of a most successful experiment. This experiment was in the shape of a resident country home for crippled or

13 Ibid., p. 380.

"Liverpool (Eng.). Education Committee. Report on the Medical Inspection of school children for the year 1913. Liverpool, 1914, p. 68-71. 
physically defective children, operated at first during the summer months but now having been extended for trial even into the winter term. A brief description is given in the report.

During the summer months of 1913 the Education Committee, for the fifth time, carried on a residential Country School for physically defective children, drawn from the special schools in the city, at the Bowring House, Roby (a large estate in the possession of the Corporation). The school was open in the first instance for a little over six months, viz., from the first of April to the tenth of October; and during that period 102 children ( 52 boys and 50 girls) had the advantage of a stay in the country. The children were sent out to Roby in two parties, each party remaining in residence for some twelve weeks. As a result of the treatment given to these children, the medical officer for the special schools certified eighteen boys and eighteen girls as fit to return to ordinary elementary schools.

The result being so satisfactory, the committee gave authority for the Country School to be kept open from month to month during the colder weather, and the school was accordingly continued, as an experiment, on the twenty-first of October, 1913, with a reduced party of twenty-five girls; with the exception of a few days at Christmas, the school has been continued with a party of twenty-five children in residence throughout the winter.

The committce has now under consideration the question of making the Country School a permanent institution, open all the year round, the results obtained being, in the opinion of the medical officer and the committee, sufficient to justify such a course.

\section{STATISTICS OF SPECIAL CLASSES IN ENGLAND}

A statistical statement regarding special schools for crippled or physically defective children appears ${ }^{15}$ in the report of the medical officer of the English Board of Education. At each one of the schools there are one or more, usually several, classes for crippled scholars.

At the end of the Code Year, July 31, 1912, there were 67

${ }^{15}$ Great Britain: Board of Education. Annual report for ror of the Chief Medical Officer of the Board of Education. London, 1913. [Cd. 7184.] p. 211. 
schools for the physically defective certified under the Elementary Education (Defective and Epileptic) Act, 1899. All of these were in England; there was none in Wales. Of these, 58 were provided by public education authorities, 9 by voluntary private agencies. The accommodation was 5,260 .

The average number of scholars on the register during the school year of 1911-1912 was 4,674.

\section{GYMNASTICS FOR CRIPPLED CHILDREN}

In a recent article $^{16}$ by Miriam Townsend Sweeney, director of physical training at the Industrial School for Crippled and Deformed Children, Boston, there was discussed the question of gymnastics for crippled children. The article begins as follows:

The giving of gymnastic exercises to crippled children may seem to some as preposterous as requiring a swimmer to propel himself in a vacuum. Certainly to those to whom bodily exercise means simply long cross-country hikes or tumbling around on the football field, or the acrobatic performances demonstrated by the German Turners, it would seem out of the question to expect the crippled child to reap any benefits or to be in any way a candidate for participation. On the other hand as excrcises may also come to mean any movement, or set of movements, which bring into activity the body as a whole or in part, we can readily see wherein the crippled child may indulge those parts which may be beneficially active, and yet not sacrifice the affected part. As the general aim of gymnastics is health, it is natural to suppose that if correctly applied, gymnastics may be as influential in dealing with crippled and deformed children as they have proved to be in dealing with the normal healthy child.

Gymnastics are divided into two kinds, educational and corrective. Educational or hygienic, that type which is constructed upon physiological principles, and corrective or medical, that type which has for its working basis pathological consideration. It is through the latter variety that we reach the crippled child.

26 Miriam Townsend Sweeney. Gymnastics for crippled children. American Journal of Orthopedic Surgery. Philadelphia, 1913, xi, 116-134. 
We may not expect these children, handicapped as they are by physical defects, and by apparatus of various kinds, to be in line for exercises requiring quick response, up to a certain point, skill and balance or any of the finer qualifications which the normal child acquires in the gymnasium.

There is with the crippled child a definite pathological condition, and the chief aim should be to adjust the child physically so that its vital resistance be increased, and its activities normalized as far as possible. Therefore, it would be judged more effective if these children are dealt with through a series of especially prescribed exercises, based on the relief of the abnormal conditions presented in the individual. These special exercises under ideal conditions should be part of the daily routine of school. Each child should have at least fifteen minutes concentrated effort directed toward his special need and carried out under the close supervision of a trained person. It has been found that the best results are in this way obtained. Beside the localizing work on the special conditions present, effort should be made to improve in general the chest capacity and thereby the circulation. Improvement along these lines tends to lessen the predisposition to disease, and these two things alone are in themselves important items in dealing with the child already so definitely handicapped.

There is another point of view in working out the hygiene of these children. While our main efforts may be directed toward active work there is in large measure a portion that cannot do active work. For these children there should be systematic, supervised, rest periods, these periods of rest being as important to these children as the periods of activity to those who may participate.

In most of the large cities to-day we find either institutions or special classes, and sometimes both, provided for the care and education of the crippled child. These children are of various types not so widely divergent from the normal as might be expected. There is, however, much difference relatively in their ages. The average boy or girl of twelve years will be finishing the grammar school, but the crippled boy or girl at twelve may be only as far as the fourth or fifth grade. This varies naturally with the amount of set-back of starting that the physical condition has enforced. Morally they are average though they more frequently show tendencies which are reflected 
from the high-handed free license they are allowed at home. We are confronted, therefore, with practically the same problem in dealing with the crippled child as in dealing with the normal with the one exception thus far of their physical differences. The fact of this similarity is an important feature.

There are then described the surgical classification of the children and the special exercises prescribed by the orthopedic surgeon for particular cases are stated in detail. The work is, of course, almost entirely individual.

A great variety of apparatus does not seem to be required, it being stated that "a plinth, a table, a trapeze, a number of benches, an adjustable pulley weight, a number of pairs of dumb-bells varying in weight from one to five pounds, and a dozen wands will be ample." The article concludes as follows:

After close supervision of over a hundred children for three years under the gymnastic conditions given in this paper we are convinced by the results gained that the field of gymnastic work should be opened to these children as well as to the normal individual. Closer supervision is of course necessary, care in adjusting the prescriptions, exactness in the detail of giving the exercises are all to be emphasized. Following the actual measurements of these children who have been for three years under treatment of this kind we find increased height and weight. Improvement in carriage is marked in many cases. There has been less sickness, no outbreaks of contagious diseases and altogether a more healthy set of children than under conditions which allow of no activity and prohibit systematized exercise. 


\title{
AMERICAN JOURNAL OF CARE FOR CRIPPLES
}

\author{
Published By the \\ Jederation of Associations for Cripples
}

EDITED BY

\author{
Douglas C. McMurtrie
}

EDITORIAL BOARD

GwIy G. Davis, M.D.

Hastings H. HaRT, LL. D.

Russell A. HibBs, M. D.

Arthur J. Gillette, M.D.

Charles H. Jaeger, M.D.

ROBERT W. LOVETT, M. D.

H. WinNetT ORR, M.D.

Konrad Biesalski, M.D. JOHN RIDLON, M.D.

ROBERT JoNes, F.R.C.S.

$$
\begin{gathered}
\text { PUBLICATION COMMITTEE } \\
\text { FOR THE FEDERATION }
\end{gathered}
$$

Miss Adelatde B. Baylis

Mrs. Helen K. Travers

Mrs. Henry B. Barnes

Mrs. George F. Shrady

Volume I Number 4

NEW YOR K

I 9 I 4 


\section{AMERICAN JOURNAL OF CARE FOR CRIPPLES}

Volume I Number 4

New York, December, 1914

\section{CONTENTS}

Modern methods of care for cripples in Germany. KonraD BIESALSKI

A shop for cripples' work. Carrie M. Seligmann . . . . . 172

Industries that cripple their employees; the New York State compensation act; meeting of the Federation of Associations for Cripples. Douglas C. McMurtrie . . . .

Feeding crippled school children in New York City. Edward F. Brown . . . . . . . . . . . . . . . . . 182

Editorial Notes . . . . . . . . . . . . . . . 186

A New Jersey institution.-Need for state provision.-Graduation of nurses at Newark Home.-Needlework as an industry.-School lunches for cripples.-Objection to hospital erection.-Sale by East Side Free School.-Brearley League exhibition.-Benefit for orthopedic ward.-Construction of the hospital building.-Making cures permanent.-Dedication of new dispensary building.-Work of the Boston school.-Francis J. Cotting.-Cripples subject of club meeting.Gymnastics for crippled children.-Hospital alumni meet.-Addition of an incline.-A moving picture film.

Bibliographical Notes . . . . . . . . . . . . . . 199

Published quarterly by the Federation of Associations for Cripples at 3505 Broadway, New York City. Subscription price, $\$ 3.00$ a yearly volume.

Entered as second-class matter at the post office at New York, New York, under the Act of March 3,1879. 



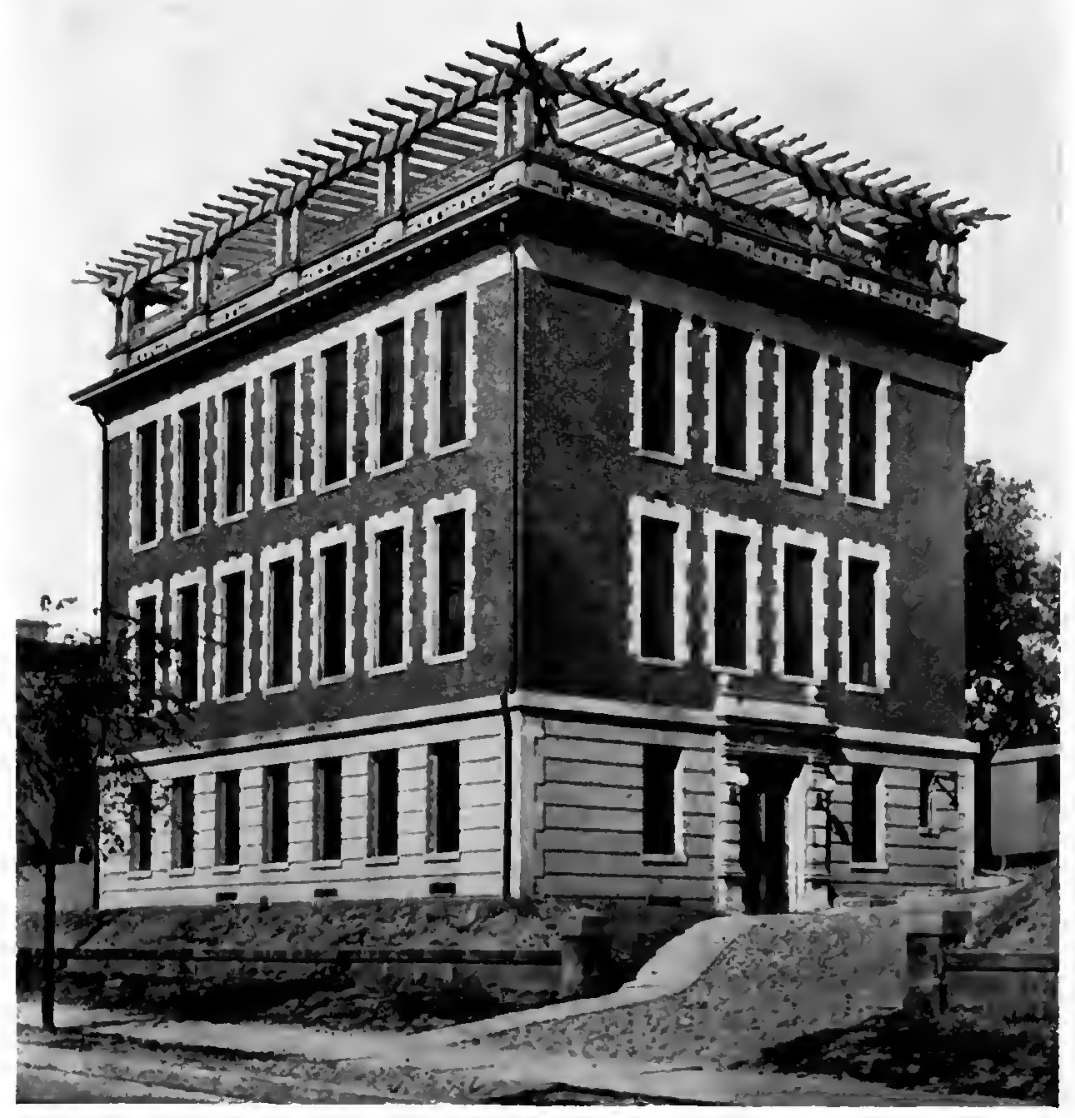

NEW BUILDIXG INCLUDING WARDS AND DISPEXSARY

[HUME FUR CRIPPLED CHLLRRA, NEWARK, N. \}.] 


\title{
MODERN METHODS OF CARE FOR CRIPPLES IN GERMANY
}

\author{
Konrad Biesalski, M.D.1 \\ Berlin, Germany
}

Almost a hundred years ago there was in operation in Berlin an institution for cripples founded in 1823 by a Dr. Blömer, and providing the same features of care as the modern cripplehome, namely, hospital treatment, primary education, and industrial training. After existing for some years, however, the establishment was discontinued.

In 1832 there was established in Munich the present 'Königliche Zentralanstalt für Erzichung und Bildung krüppelhafter Kinder.' As this institution continued permanently, it must be considered as the real pioneer in the field of organized care for cripples-which is thus eighty years old.

During the early decades of this period very few institutions were started, but in 1886 an active movement, assoeiated with the name of a protestant pastor, developed in northern Germany, the impetus being derived from the example of Pastor Knudsen in Copenhagen. The effort resulted in the founding of numerous institutions.

The greatest progress was made, however, during the last decade, this being due to the increased general interest in soeial

\footnotetext{
${ }^{1}$ Konrad Biesalski. Die moderne Krüppelfürsorge in Deutschland. Zeilschrift für arzlliche Fortbildung. Jena, 1913, x, 155-159. An address delivered before a meeting of the English Royal Institute of Public Health, in Berlin, 1912. Translated by Douglas C. McMurtric. Indebtedness is acknowledged to another version which has appeared in the Journal of State Medicine, London, 1912, xx, 595-604. Dr. Biesalski is the director and chief surgeon of the 'Berlin-Brandenburg KruppelHeil- und Erziehungsanstalt,' editor of the Zeitschrift für Krüppelfürsorge, and a member of the editorial board of this JourNal.
} 
questions aroused by the legislative industrial reforms and the inauguration of state disability insurance. Another contributing factor was the rapid industrial development following upon the establishment of the empire, this bringing into circulation the money requisite for large measures of social amelioration. There was thus existent general sympathy with the needs of cripples and the ability to minister to them. The only thing still needed was the requisite initiative and a direction of the impulses toward the best means of practical expression.

These latter influences were provided by the census which was taken during 1906 of all cripples under sixteen years of age throughout the whole of Germany. This statistical inquiry showed the following important results:

(1) It opened the eyes of the entire nation, from the highest officials in government departments to the lowliest village schoolmaster, to the fact that the cripple could be materially helped.

(2) While former inquiries had only dealt with isolated districts, and were thus valueless for purposes of general application, by this inquiry were elicited and made possible of coordination the relations between the needs of and provision for cripples in each individual district. There was thus laid a solid basis for practical reform.

(3) The statistical inquiry crystallized the vague conceptions of the term 'cripple' into a definite formula, and this definition has been accepted for practical purposes by the federated states of Germany and by all responsible authorities. It runs as follows: "A cripple in need of institutional care (heimbedürftig) is an invalid who in consequence of congenital or acquired nerve, bone, or joint disease (other physical defects also occasionally supervening), is hindered in the natural use of his body or limbs to such an extent that he is not capable of adjusting himself to his environment; this lack of harmony admitting of rectification only by appropriate treatment in an institution which, by virtue of its special facilities of a combined medical and educa- 
tional character, offers the only possibility of developing his remaining mental and physical powers to their utmost economic value." This definition indicates that it is not mere physical defect which calls for charitable aid, but that the social and economic factors count as of equal importance. In our sense of the word, therefore, the severely deformed child of wealthy parents is not a 'cripple' as the father is quite capable of guarding him from social stress. But a girl, for instance, with only a slight degree of scoliosis, if she is at the same time an orphan, and a deaf-mute, and perchance also pthisical, is to us eminently a 'cripple.'

(4) In this way all units out of the vast army of cripples who were in no need of social protection were eliminated. A second distinction was made by dividing the remainder into two categories: the heimbedürftig and the nicht heimbedürftig, i.e., those needing - care in a resident institution, and those not requiring residential care. Whereas, in the past, all cripples had been regarded as institutional cases, the number of the latter was now reduced one-half by a process of exclusion, and the potential cost of treatment also diminished in consequence. This left workable numbers which could be dealt with if good will, energy, and a due regard to economy were brought to bear upon the task.

(5) Having defined the cripple as an invalid, the interest of the medical profession regarding his physical necessities was aroused. The orthopedic specialist particularly showed a willingness to come to the rescue.

All these factors united in the initiation of an enthusiastic movement throughout Germany which resulted in doubling the number of institutions for cripples in ten years.

The census of 1906 revealed the following facts:

In 1906 there were in the whole German Empire 100,000 cripples under the age of 16 . Of these, according to expert medical opinion, 52,000 were in need of resident institutional care; 10,000 expressed their willingness to avail themselves of 
such treatment. The available beds, however, numbered only 3,000 . This discrepancy has, fortunately, been largely overcome since that date. Though the population of Germany undergoes a yearly increase of three-quarters of a million-and this naturally increases the number of crippled persons-the institutional development has overtaken the cripple increase. While there were only twenty-three cripple institutions in 1902, we can today count fifty-three, and the number of beds has increased in ten years from 1,622 to 5,932 .

About one-half of the existing homes are associated with some religious denomination-usually protestant, though there are some catholic; the other half are undenominational. In those of the latter type the practice of constituting the surgeon in charge as director of the institution is gaining in favor.

At the present time there is one helper to every 4.5 crippled children. This shows the excellent development of provision which has been attained. The average annual expenditure per capita is 415 marks, or slightly over one hundred dollars.

The feature in which the German institutions differ from those in some other countries, especially England, is that with us the larger proportion of the expense is derived from public funds. Even if we shall never dispense with the generous aid of private philanthropy - and we are far from wishing to do so if for no other reason than because of its moral value-the general trend of our efforts is to secure the necessary funds from public sources, instead of relying, as in England, mainly on private generosity. It is only in this way that economical administration and farsighted organization can be rendered practicable. We are well supported by legislative action-e. g., in Prussia we have the so-called Dotationsgesetz.

In others of the federated states the socialization of care for cripples has been already introduced as, for instance, in Oldenburg, or the state makes yearly grants, directs the Landesorganisation, or takes an active part in the administration of a Landesanstalt for cripples. 
In general what counts with us most in Germany in collecting funds for the care of cripples is the maxim: "Let us not be dependent on charity, but let us have financial security through the responsible co-operation of state and local authorities."

A good example of what a local council can accomplish is shown by the municipal authorities of Greater Berlin, who pay the regulation hospital grant for each crippled child placed in an institution. The late director of the Berlin Poor Law Board, Stadtrat Muensterberg, who was also known and respected in England, once said that the best way of helping a destitute patient was to make a healthy man of him, and this principle, which he derived from a profound knowledge of social conditions, he applied to care for cripples.

The municipal authorities of Greater Berlin have also, in conjunction with the Landesdirektor of the province of Brandenburg, rendered possible the erection of a new Berlin cripple institution, guaranteeing the interest and sinking fund for the capital outlay.

That care for cripples in Germany has met with such signal success in securing public financial support ensures it the best prospects for an established and prosperous future.

The aim of the institutional care is to make the cripple a selfsupporting member of the community. This object should be internationally universal. But as regards the beneficiaries of care, there is some distinction to be made between English and German methods. In Germany, in accordance with the aforesaid definition, the term 'cripple' is held strictly to apply to individuals who exhibit functional disturbances connected with the movements of the body or limbs. But crippled individuals who also suffer, for instance, from tubercular glands, harelip, or rachitis in its most glaring form, or who are idiots or epileptics, are, generally speaking, excluded from the benefits of institutional training. It is true that the movement in aid of cripples maintains friendly co-operative relations with other provinces of social work-prevention of infant mortality, care 
for epileptics, deaf-mutes, or the blind, improvement of housing conditions, the prevention of intemperance, and the like-and that provisional care is taken of children who do not come, properly speaking, within the prescribed limits, until, at all events, some defect needing special treatment has received due attention. But the effort to care for cripples has its own field clearly delineated and any duplication of other social efforts can only react inimically to its own efficiency.

All the German institutions-of which the largest accomodates five hundred, and the average capacity being ninety-nineare divided into three sections, the hospital, the school, and the industrial department. All three operate under one roof, under one management, and constitute an integral organization. This arrangement insures the most profitable employment of time, money, and energy, and achieves the best possible results.

The hospital section comprises an operating theatre, medicomechanical apparatus, Röntgen laboratory, drill-hall, orthopedic workshop for the manufacture of iron braces and appliances. Every institution has a medical director and a number of assistants. The list of directors includes some of the most distinguished names in German orthopedic science.

The great advances in German orthopedic surgery since Hoffa first raised it to the rank of an independent science have always met with generous recognition in England and other foreign countries. But I may point out that modern modifications of the method of tendon-grafting first introduced by an Austro-German, and the new methods of nerve-operation in Little's disease in connection with the nerve-termini of either the spinal cord or of the periphery were first practised by German surgeons.

In the school section, the curriculum is designed in accordance with the scheme of the German elementary school, as only scholars of elementary school grade find their way into these institutions. In the Berlin institution an educational inspector. is in charge of the school section but comes under the authority 
of the medical director. In the cripple school, instruction is also provided for backward children in the Hilfsklassen or special classes, for which specially trained teachers are selected. Continuation and trade classes are also arranged for the industrial pupils; these complying accurately with the legislative requirements. In general principle, the instruction is largely manual, e. g., 'learning by heart' is avoided as much as possible and for this is substituted teaching by observation and the handling of concrete objects, by copying such forms in plastic material, and similar methods. This plan of instruction is especially suited to crippled children as it provides a certain amount of exercise for them.

In the industrial department, instruction is given in eightyone different occupations, of which two-thirds are for boys. All the male students enter the trade school in their fourteenth year and, in compliance with the law, are entered on the Trade Registry. At the expiration of three years' apprenticeship they leave the institution as properly examined and qualified workmen.

In recent years, large and magnificent institutions with complete modern equipment have been erected in various localities. By far the most palatial of these is the institution at Munich, which has been erected by the Bavarian authorities. There are also new buildings projected at Berlin, Nuremberg, Beuthen, Cologne, Wiesbaden, and other places.

You will be astonished that I speak only of institutions, as though this comprised the only method of provision for cripples in Germany. As a matter of fact it is the method which in Germany is still predominant, and the majority of experts are probably of the opinion that it is the method yielding the best results. But that form of cripple care which has been developed in England with such excellent results-the 'ambulant' method of treatment in orthopedic dispensaries-is also gaining ground in Germany.

In 1902, next to nothing was done along such lines. Then 
the 'Bayrische Genossenschaft des Johanniterordens' began the work of bringing crippled children from various parts of Bavaria to Munich, where they received treatment.

And since the statistics had strictly divided the cripples into two classes-'institutional' and 'non-institutional'-provision for ambulant treatment began to appear in every direction. Whereas in 1902 but 200 cripples, in two places in Germany, received ambulant treatment, there are now at least 36 institutions making such provision, handling 13,000 cases yearly.

The enormous expansion of care for cripples in Germany during the last ten years may best be gauged by considering that whereas in 1902 only $8 \%$ of all the cripples were cared for, the percentage to-day is 21.6. If the same rate of progress is maintained, it is within the range of possibility that in ten years more we may be able to say that, taking them as a whole, each crippled child in Germany is receiving its due share of attention.

It is true that we are still a long way behind the model arrangements of ambulant provision existing in London, and behind the admirable cripple dispensaries in New York and Milan; but we are on the right path and, as Germany has earned the reputation of making the best provision as regards institutional care, so we may hope that the time may not be far distant when ambulant provision for cripples may be equal to the demand.

In Berlin and other large cities, we shall also probably soon have to make arrangements for collecting children every morning by a special omnibus, taking them to centres where they can be treated, instructed, and fed, and returning them to their parents in the evening. We shall have to organize non-residential day schools for non-institutional crippled children, and non-residential continuation schools for those who have left school.

We are also backward in regard to cripples' labor exchanges, in which respect France is far ahead of us. It is true that a 
beginning has been made. There is a special society for this purpose in Berlin, in Munich the municipality has taken the matter up, and in Hamburg and Altona the cripples themselves have organized a union for self-help. But what we lack here is the French system of 'work depots', where the cripples can go every day to exercise their calling and pursue their trades without further trouble or expense. This also, however, we will achieve in time, so that we may make good our contention that properly organized care for cripples converts the recipient of alms into the tax paying citizen.

Now a word regarding the German organization for the care of cripples. Originally the work was entirely in the hands of religious directors who held periodical conferences-and still do, with most beneficial results. Three years ago the 'Deutsche Vereinigung für Krüppelfürsorge' was established under the presidency of Geheimer Obermedizinalrat Professor Dr. Dietrich, of the Prussian Ministry of the Interior, for the purpose of federating the various activities for the care of cripples in Germany, irrespective of their religious affiliation. This association counts among its members not only all the German homes and societies for cripples, but also a large number of public bodies, councils, social unions, and the like. It publishes the Zeitschrift für Krïppelfürsorge which, as managing director of the association, I had the honor of founding and now edit. Among the collaborators of the Zeitschrift you will find the name of the leading representative of orthopedic science in England, Mr. Robert Jones of Liverpool. The association has also published a guide to measures of care for cripples, Leitfaden der Krüppelfïrsorge, which is acquired by public school authorities, schools, associations, and libraries, and serves as a practical book of reference. It also maintains a central office where advice and information are available to inquirers.

Every two years the association holds a convention. The first was held in Berlin, the second took place recently in 
Munich under the presidency of Prince Ludwig of Bavaria, himself a physician and surgeon.

In order to promote lectures descriptive of the nature of deformity and the favorable prospects resultant upon proper treatment and care, the association has prepared several hundred lantern slides, and also a moving picture film, depicting the daily activity at the Berlin institution. By these means the facts are given wide publicity. Finally, the association arranged an exhibit demonstrating modern methods of care for cripples at the 'Internationale Hygieneaustellung' in Dresden, where it had a separate pavilion for the purpose. Over 300,000 persons visited the exhibit; on some Sundays there were 5,000 in a day.

By far the greater part of the exhibits are now housed in a small provisional museum in Bayreuther Strasse, 13. It provides the nucleus of a large museum on the care of cripples, which will be crected on the grounds of the new Berlin institution in the Grunewald Forest.

This in short, is what I have to tell you of the facts and principles of modern care for cripples in Germany. You will see that this province, small as compared with large social measures or the broad field of social hygiene, is permeated by a keen, healthy, progressive spirit. Many of the efforts made during eighty years' experience have justified themselves and will endure; others are still in the experimental stage; others again have had hardly time to manifest the first signs of young growth.

But the transactions of our two conventions have demonstrated the existence of a highly gratifying degree of earnest enthusiasm and a spirit of helpfulness. For my own part, and with me the pioneers of social care for cripples in Germany, I hold that so complex a mechanism would itself be crippled in its activities were it subjected to rigid uniformity and officialdom. I also think that by reason of differences in daily habits, social ideas, and even in climate and landscape, care for cripples in Germany will always tend to assume a form different from that of 
similar work in England, Norway, or Italy. But in spite of this, all countries may learn from one another and thus effect improvements in their own work.

It would, therefore, be a cause for gratification, were representatives from the domain of care for cripples in various countries to unite for the organization of an international congress. The feeling which must be common to all of us, and that inspires us in our work, must be the innate satisfaction inseparable from all efforts to lend a helping hand where it is most needed, together with the desire to give the innocently handicapped crippled child a new joy in life, and to assist him to a position of economic independence. If, therefore, the time should come when you receive from us a friendly summons to attend an international congress on the care of cripples, we earnestly hope you may see your way clear to accept an invitation most heartily extended. 


\section{A SHOP FOR CRIPPLES' WORK}

\section{Carrie M. Seligmann \\ New York}

Great progress can be recorded, during the fifteen or twenty years just passed, in regard to the care, the education and the training of cripples. Previous to this period, the hospitals and dispensaries were doing their utmost to relieve and possibly cure the sufferers, but when this had been done, the patient was discharged.

A few schools were eventually established through private philanthropic efforts, and the next step was to convince the Board of Education of the City of New York that there was a sufficient number of these unfortunate children to justify the formation of special classes, in various parts of the city. In several instances, the Board of Education works hand in hand with previously established organizations. Except in the case of the entirely helpless cripple, who should have custodial care; and the mentally afflicted, who should be placed in a separate category; no crippled child in New York City need be deprived of educational advantages enjoyed by the normal child.

With physical care and mental training provided, the problem develops on the economic side. After school days are over, what prospects are open to the cripple? The one whose handicap is a slight limp, a scarcely perceptible curvature, or a pair of uneven shoulders, which do not seriously hamper his movements, can take his or her place with the average worker. But the seriously deformed, the maimed, and those whose appearance is unpleasant-these cannot compete in the open labor market. Even if the academic or industrial training fits this type of cripples to match their ability with that of the able-bodied 
workers, the possibilities open to them are extremely limited.

The average employer finds his business problems sufficiently complicated, in these days of strenuous commercial and industrial competition. He is not willing to add to his burden, by providing special arrangements and rules for handicapped workers.

Those of us who have been longest concerned with the economic questions affecting cripples, have reached certain conclusions, and this article is being written in the hope of securing co-operation, that will enable us to concentrate our energies on an effective plan for working out a solution of difficulties and bringing together all those interested in the subject.

The efforts thus far made have developed certain fundamental facts: One, as stated above, is the difficulty in securing positions for cripples; another is the cruelty of training them for positions which they will never succeed in obtaining; the third is, that under favorable conditions some of the apparently helpless ones can be taught to do salable work, and the fourth is, that, since the work of the handicapped person is necessarily slow, emphasis should be placed on the quality of the work.

The needle trades offer the largest scope for women and for badly crippled men. There are in New York five organizations, possibly more, that provide training in these. There are three institutions where men or boys may secure trade training in jewelry work, basketry, reed furniture, cabinet work, draughting, engraving and metal work. Two or three of the institutions maintain workrooms, where special provision is made for the comfort of the crippled worker and special facilities supplied, to minimize the hardship of the handicap. Orders are solicited and filled, for the output of these workrooms, and a regular weekly wage paid, based, as nearly as possible, on actual earning capacity. As the number of workers increases, the method of disposing of the material thus produced will have to be changed. Specially organized sales and exhibitions must be 
superseded by a permanently established salesroom and office, where finished work can be displayed and orders received. But-the establishment of such an undertaking requires a substantial foundation, to begin with.

Existing organizations cannot assume such a burden, particularly just now, as their resources are strained to the utmost in fulfilling their existing obligations. One of the main factors in bringing about the Federation of Associations for Cripples was the hope of effective co-operation at this point. The Shop Committee was appointed for this purpose and a tentative effort was made, last year, to start the ball rolling. Two joint sales were conducted; one under the auspices of The Crippled Children's East Side Free School, at its annual sale, at Delmonico's; the other at the Women's Industrial Exposition at the Grand Central Palace.

Independent organizations, working along different lines, can find a point of convergence, when all are animated by the same desire: To render a peculiarly unfortunate group of people self-supporting and self-respecting. The Shop Committee believes in its mission, believes that a Federation Shop can and should be established and believes that its appeal for support will justify itself, by the benefit it will confer. ${ }^{1}$

\footnotetext{
II had been planned, when this article was under consideration, to include the description of some typical instances, to illustrate the conditions referred to. A list will be prepared and made available for examination if anyone interested cares to consult it. Correspondence is invited and should be addressed to Mrs. Albert Seligmann, chairman of Shop Committee, Federation of Associations for Cripples, 780 Park Avenue, New York City.
} 


\title{
INDUSTRIES THAT CRIPPLE THEIR EMPLOYEES; THE NEW YORK STATE COMPENSATION ACT; MEETING OF THE FEDERATION OF ASSOCIATIONS FOR CRIPPLES
}

\author{
Compiled by \\ Douglas C. McMurtrie \\ New York
}

The Federation of Associations for Cripples at its semiannual meeting held in the Assembly Hall of the United Charities Building on December 1, 1914, presented two topics for discussion: 'The Workmen's Compensation Law,' and 'Industries that Cripple their Employees.'

The report of the Executive Committee of the Federation was presented by Miss Eleanor Adler, chairman. It read as follows:

The work of the Federation has been carried on without interruption since the April meeting. The past summer has bcen the first one in which the office has been kept open-a new secretary, Miss Winifred Putnam, having been engaged in June. The work with the cripple cases has been going on steadily. Times have changed since we had to hunt up our cases in schools and tenements, and the secretary is almost swamped with the number of applicants. Relief agencies, schools, hospitals, and so forth, are all making use of the Federation and the cripples themselves have told others about the office. In fact, the amount of help we can give is now merely a question of funds, and the half-time basis we are working on at present docs not let us do what we might.

The census of cripples started last year is being continued, and will undoubtedly prove of great value. When we know exactly the number of cripples in New York, and where and under what conditions they live, we can plan for the whole situation with greater efficiency. 
Threc numbers of the AMErican Journal of CARE for Cripples have been issued by Mr. Douglas $\mathrm{C}$. McMurtrie and the Publication Committee, and a fourth number completing the first volume will be published very soon.

Miss Bond, who was elected treasurer at the last annual meeting, resigned shortly after, and at the request of the president, her place was filled by Mr. Thomas S. McLane, for the remainder of the year. Our vice-president, Mrs. Goldman, tendered her resignation this fall, owing to ill-health and too many calls on her time and strength. With regret it was accepted. We were fortunate in persuading Miss Florence Sullivan to allow her name to be put in nomination.

The Committee hope that at the next meeting they can present some plans for a Federation Shop where the different associations can sell the articles of jewelry, embroidery, furniture, and so forth, which they produce. It may prove feasible to combine this shop with an employment bureau and a workshop for the severely crippled. Whatever direction such plans may take, the Committee believe that the inauguration of such a shop is the next important step before the Federation.

The report of the Executive Secretary regarding the active work of the Federation was presented by Miss Winifred Putnam:

From April 6, 1914, the date of the last semi-annual meeting of the Federation, to November 28, 1914, 151 new cases have been referred to the Federation, and 11 old cases have been re-opened. Of this total, action has been taken in 119 cases, leaving 43 still under consideration.

To follow out the plan reported upon at the Federation meeting in April-to obtain from hospitals, schools, homes, social service agencies, and so forth, the name and address of every cripple coming under the care of each agency, with as detailed information as possible regarding his physical care, education, and industrial training-circular letters were sent to all such agencies, asking for copies of their records. In most cases we have met with hearty response, and the registry has been started with 977 cards on file, and more than twice that number being prepared for us. It often happens that two or even three organizations send records of the same case, and not 
infrequently $I$ find that it has been handled by each organization without definite knowledge of what previous action has been taken. When information so received from two or three sources is combined in one central bureau, the matter of handling that particular case must be greatly simplified. This has already been proven by the Social Service Exchange of the Charity Organization Society, but the cripple problem is in itself so tremendous that special records are necessary to facilitate its study.

The report of the Nominating Committee was presented by Miss Bond. The following officers as nominated were elected:

Mrs. George F. Shrady, president; Miss Florence Sullivan, vicepresident; Mr. Thomas S. McLane, treasurer; Mrs. Ernest Strauss, recording secretary; Miss Eleanor $\mathrm{H}$. Adler, chairman executive committee.

A report on the present status of the Federation was read by the President, Mrs. George F. Shrady. This report follows.

After an interval of nearly eight months since our public meeting in April last, we pause for a few moments to consider how the Federation stands in relation to the various interests which have grown out of its activities. You will recall that at our last meeting $I$ announced the plan of creating an associate members' class, whereby those not directly connected with any society working for cripples could contribute a few dollars annually to the Federation's work. Some of us tried diligently to secure associate members, with the result that a little over $\$ 200$ annually will be subscribed in this way. With the present scheme of organization $\$ 1500$ should be subscribed by associate members. It can readily be seen, therefore, how far the results fall short of the needs. There was no general response from the associations comprising the Federation of which there are now seventeen. The appeal was made but the almost universal reply was that each board was struggling to meet its own financial needs and beyond paying dues to the Federation, could not, in justice to itself, divert funds from its own specific work to the broader purposes of the Federation. Personally, I fully appreciate the justice of this attitude and the query comes to me again and again-should the Federation cost so much? 
Are we not excceding the functions of a federation in some of the things we have undertaken?

One of the principal directions in which we are liable to err is in the matter of finding employment for those who are stranded and helpless. These cases need attention and arouse our sympathies, but.it takes nearly the entire time of a paid secretary to investigate and help even a part of the cases which are brought to the attention of our office. I understand that the Federation was never intended to conduct a relief bureau, but in listening to the report of our Executive Secretary, one is impressed with how many cripples have been placed in positions and assisted in various ways. There are well known and opulent societies, such as the Charity Organization Society and the Association for Improving the Condition of the Poor, which should look out for this class of poor people. I am told that these societies pay no attention to cripples. My answer to this is that by the several hundred cases the Federation has helped in the past two years it has been fully demonstrated that the industrial wants of this class of poor persons are sufficiently extensive and pressing to require recognition from the agencies already existing. I think if the matter were laid before the governing bodies of these two societies, they would see the injustice of discrimination against any special class of poor persons. I intend to investigate this situation and have something definite to report to you at our next public meeting.

The Federation should adhere to the original intention of being a source from which may be obtained all necessary information regarding work for cripples, as well as being a means through which certain mutual benefits may be secured by the co-operation of the associations composing the Federation. It should avoid relief work and turn it over to the existing and well known agencies for such work. I cannot make this assertion too emphatic. It is far better for the Federation to concentrate on a few leading needs which can be met through co-operation, than to do in a meagre way what richer societies organized primarily for relief can do so much more easily.

The shop for the sale of work done by cripples is what a majority of the associations in the Federation are clamoring for. Last year at this time we made a very good beginning by getting six associations to hold their annual sales jointly at Delmonico's, but shortly after that 
some of the moving spirits in the plan were obliged to discontinue work, and later on, the lethargy which the European war has produced in so many commercial and philanthropic activities seized the Federation, and there has been no further development of the shop for cripples' work. I trust, however, that from to-day on there will be a renewal of interest in this project.

The fourth issue of the first volume of the AMERICAN Journal of CARE FOR CRIPples will soon be published. Considering that the JOURNAL is as yet an infant publication only ten months old, and that the European war deprives it of foreign subscribers and contributors from which it should have gained much support, the Federation has reason to be grateful that the publication has done as well as it has. It received favorable editorial comment from the leading medical journal of the country as well as being highly commended by other notable authorities.

As soon as the new Workmen's Compensation Act went into effect on July 1, 1914, reports came in from all sides that after the inauguration of the law it became very much more difficult to secure employment for cripples. Mr. William C. Archer, manager for the Workmen's Compensation Commission, was therefore invited to discuss the law and its possible effects on cripples. Following is a much condensed digest of Mr. Archer's statement.

The idea of social insurance is not a new one, having been first tried in the Middle Ages. The idea of it is most reasonable, and the cost of operation is actually not increased. There are various manufacturing charges such as rent, insurance, depreciation, the replacing of broken or worn-out parts-and it is quite logical to include in this category the charge for workmen broken or worn out in operation. This charge is the compensation cost.

It is not a new cost, but existed before in the expense of damages recovered in long law suits as a result of which the manufacturer paid out a sum very little of which went to the worker injured, the greater part going to lawyers, court charges, and so forth.

The new plan provides the maximum benefit to the worker injured and also eliminates several points of injustice in the common law such as the 'fellow servant' provision. 
In the future the new law will operate to the advantage of industrial cripples as they will receive regular weekly renumeration for their disability and will not, therefore, be indigent charges on the community.

Mr. McMurtrie called attention to the alternative of insurance with private companies or the state fund, stating that the private companies, making rates on the basis of the individual risk and the possible compensation involved, would discriminate in their charges against factories employing many cripples. He asked Mr. Archer if many employers had not insured in such private companies because their rates were lower than the state fund. Mr. Archer replied that quite the contrary was the case; that the state fund charges were $7 \%$ lower than those of the private companies, and that eventually it would be almost certain to eliminate them. The state fund had flat rates which were not dependent on the risks of individual persons (crippled or otherwise) employed.

Miss Adelaide Baylis told of the difficulties she had experienced in securing positions in the jewelry trade for crippled boys trained by the Brearley League, since the new law went into effect. Refusals to employ the crippled young men were always explained as being due to the compensation law.

Miss Winifred Putnam, speaking of the difficulty of securing employment for cripples, emphasized the importance of the question, pointing out how much good training is frequently undone in the discouragement incident on failure to obtain work.

The subject of industries which cripple employees was discussed by Dr. Virgil P. Gibney, of the Hospital for the Ruptured and Crippled. A brief digest of his remarks follows:

The great majority of cripples caused by industry are maimed or accident cases, usually eventuating in amputations. This work lies in the field of the general hospitals and is rather outside the orthopedists' own particular province. Very few of the cripples from disease, which is the type served by the orthopedic hospitals, can ascribe their crippled condition directly to industrial causes. 
All industries contribute indirectly to the causation of cripples in so far as their working conditions are good or bad with respect to ventilation, infection, and general health. If these factors are pernicious they will predispose a worker to the contraction or development of diseases making for deformity.

It used to be considered that some trades were productive of deformity, but it has since been discovered that their effects were only indirect as just described. One of the few deformities which might be considered as directly occupational is flat foot, which is frequently acquired, for instance, by saleswomen, motormen, and so forth; with the salesgirls in department stores the difficulty of constant standing is enhanced by their low wages which prevent them from buying proper shoes to support their feet.

One of the greatest difficulties with which the orthopedic surgeon has to contend is his inability to get his patients early enough in the course of their disease. This is probably the most important single factor in their cure or improvement.

Dr. Felix Adler said that at the present time the Federation should insist on the munificent support of the public. In Europe they are making cripples; here we are curing and caring for them. It is important, Dr. Adler said, to make cripples economically valuable, to find their special talent and develop it, so that they may have over others superiority in some particular field. In closing he spoke of the efforts of Gustav Werner to provide industrial occupation for cripples, which he had become acquainted with when traveling in Germany in 1875. 


\title{
FEEDING CRIPPLED SCHOOL CHILDREN IN NEW YORK CITY
}

\author{
EDWARD F. BROWN \\ Execulive Secretary, New York School Lunch Commillee
}

Enlightened school authorities have awakened to the need for especial skill in the nurture of exceptional children. The crippled children are only now coming into what remains of their birthright. Their educational career is being surrounded with every facility. Special classes are formed to meet their peculiar requirements. The conduct of these groups presages an era of a profound social philosophy which seeks to assist the helpless to become self-supporting and self-respecting citizens who through their acquired ability to produce are dependent merely on their own resources for the means wherewith to live. This is a radical departure from the ancient method of shunning the unfortunate cripple, whose choice was narrowed to the life of a beggar or the almshouse. This generation seeks to help the cripple to learn, to work, to earn, and to take his place in the community with the more fortunate. While this humane and wise solicitude has not yet reached to the limits of its profession, other agencies, working harmoniously with the educators, are seeking to sustain and keep intact the physical welfare of these blighted lives. One such movement is the provision of hot, nourishing, noon meals for crippled children in the public school.

Cripples have had usually to bring a package of dry, cold lunch to school for the noon recess, or return home in the vehicle provided for the purpose, with its swinging, jolting and jumping movements. Whether it was the dry lunch from home eaten in the school, or the hasty trip with its hurried lunch at 
home, both presented unsatisfactory results and were often objectionable.

The New York School Lunch Committee, operating through the generosity of Mrs. Elizabeth Milbank Anderson the pennya-portion hot lunch service in seventeen schools with a register of over 25,000 school children, seeks to make its facilities available to the crippled children of the public schools wherever possible. This service was first extended to Public School No. 107, Manhattan, where children sit on specially constructed benches to a hot meal which now takes the place of the dry, cold food brought from home. At Public School No. 69, Manhattan, with its 86 crippled children, there has just been inaugurated similar service.

The foods which are provided are prepared under the direction of Miss Edna M. Klaer, a dietitian, and are cooked in sanitary kitchens by workers who have been subjected to rigid health tests to preclude the possibility of disease transmission. The raw foods are purchased in factories which have been inspected for insanitary features, and the foods are submitted to the laboratories to detect injurious matter.

The children's choice of food is directed only to the extent of insisting that the first penny shall be spent for a bowl of hot soup. The menu is changed daily, and the variety adapted to many preferences, as can readily be seen from the following partial list (to which is appended the respective caloric value):

$\begin{array}{lrlr}\text { Green pea } & 128.31 & \text { Macaroni and tomato } & 105.29 \\ \text { Cream of barley } & 120.47 & \text { Split pea } & 100.70 \\ \text { Cream of macaroni } & 113.57 & \text { Tapioca and tomato } & 90.83 \\ \text { Lentil } & 112.77 & \text { Corn } & 90.66 \\ \text { White bean } & 111.27 & \text { American vegetable } & 85.00 \\ \text { Scotch broth } & 84.91 & \text { Clam chowder } & 82.00\end{array}$

After taking soup the child may then purchase of the other dishes, some of which are here enumerated, together with the caloric value of each, any one of which costs one penny. 
Rice pudding

Bread pudding

Chocolate pudding

Baked beans

Baked macaroni

Potato salad

Lentil salad

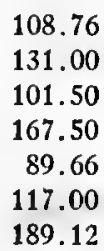

Apple sauce.

Egg sandwich

Butter sandwich

Jam sandwich

Cheese sandwich

Prune sandwich

Dates
108.57

236.28

247.25

227.75

250.17

243.20

200.00

Fresh fruits are always on the table in season. It is estimated that the child requires approximately four to five hundred calories for the noon meal. It is obvious that, carefully chosen, an expenditure of three cents gives the child a good and adequate meal.

Such a service as is here described easily eliminates the objections to the package lunch brought from home, which is dry, cold and often lacks the essentials which make up a balanced, adequate and nourishing ration. Of ten these packets are made up of the leavings of the family meal of the night before. Little or no care is given to the proper care of this food over night, which frequently results in its deterioration. Even when the food is freshly prepared or purchased (and it is often purchased prepared) it lies in ill-ventilated cloakrooms in the schools where the mingled odors of many wraps are absorbed by the food. This is especially objectionable on moist or stormy days. Such foods, with their doubtful careers, have but a questionable value. Moreover, it invariably costs more than the price of the freshly prepared, expertly sclected and hot nourishing foods provided through a carefully administered school lunch system.

Many of these little cripples come from homes which lie in the deep shadows of poverty. Some of the mothers are compelled to work in the factories, where they supplement the meagre incomes of the chief breadwinners of the family. To such it means an extra early awakening in the morning to prepare the package lunch, subject as it is to the exploitation of food stores where insanitary conditions and adulterated foods go hand in hand to undermine health. 
No. 4 . AMERICAN JOURNAL OF CARE FOR CRIPPLES

At Public School No. 69, which will soon be opened as a lunch centre, about half of the children in the cripple classes have the added affliction of being tubercular. The need for proper nourishment for these children is especially pressing. The need for proper food to prevent the nontubercular from infection is none the less urgent, however.

There are in the public schools of New York City 39 classes for cripples registering 657 children. These shattered lives deprived of so many of the joys which others have, might at least be given the means wherewith to build up their frail frames to resist the misfortunes to which poorly nourished systems are heirs.

It is hoped that those who have the care of crippled children may be encouraged to provide for them a noon lunch service in the school building. 


\section{EDITORIAL NOTES}

\section{A NEW JERSEY INSTITUTION}

In the December issue of the state magazine of New Jersey, appears an articlel dealing with provision for crippled children, with especial reference to the work of the Newark Home for Crippled Children. After a sketch of the historical development of care for cripples, it states as follows:

The United States, in its provision for cripples, holds high rank among these countries. Its first institution was established in 1863, and over fifty more have been founded since that time.

New Jersey has done her share in this field. The largest institution for the deformed in the state is the Home for Crippled Children, Newark. The Home has two buildings in a splendid location at the intersection of Park and Clifton Avenues, one of the highest points. of ground in the city, plentifully supplied with fresh air and sunshine.

Here there are cured each year many of the crippled children who come under the care of the Home. Others, who cannot be entirely cured, have their condition greatly improved. The actual work is similar to that of regular hospital, except that there are many special facilities, and provision is made to keep the children during the long period of treatment, which is generally necessary. Almost equal in importance to the surgical treatment is the abundance of fresh air on the open sleeping porches, and the sufficiency of eggs, milk, and other nourishing foods.

There is seen typified in the work of this institution the change which has come over the attitude of the community toward the cripple. In this Home the effort is not to provide a retreat for the deformed apart from the public gaze, not to provide an asylum home

${ }^{1}$ Douglas C. McMurtrie. Eliminating the cripple from the community; concerning the Newark Home for Crippled Children. 'New Jersey', Jersey City, 1914, i, 116-121. 
where incurables may pass their days, nor even to take young people already crippled and endeavor to teach them special trades. The main emphasis is placed on reaching young children suffering from maladies which make them cripples and cure those progressive diseases before the permanent harm is done. In this way the work is really to prevent cripples, and if the provision were adequate enough, with certain important types of deformity, this end could be approximately attained.

There is, of course, need for various types of care for persons permanently crippled, and for cripples from birth, but in any work the ultimate end of prevention should be kept constantly in view.

There is a saying abroad that the best thing that can be done for the cripple is to make a well person of him, and the truth of this does not require demonstration. It is, however, a fact of great import-. ance that, in the cases of many cripples seen about the streets, they need never have been so deformed had they received proper treatment at the right time.

This kind of treatment the Newark Home for Crippled Children is providing every day. It is doing its share toward eliminating the cripple from the community.

\section{NEED FOR STATE PROVISION}

In the same magazine an editorial' ${ }^{2}$ points out the desirability of and the need for a state institution for crippled children in New Jersey.

Though some crippled children are excellently cared for in some individual cities and communities, there are many more in other localities for whom there is available no provision whatever. This is particularly true of crippled children in country districts where even the ordinary hospital facilities are not possible of access.

Such children, furthermore, need special care and educational training which the average hospital cannot provide.

Both these requirements are fully met by a state hospital school for crippled children. Such an institution, located in the country, can receive children from all sections of the state, rural or urban,

${ }^{2}$ Crippled children (editorial). 'New Jersey', Jersey City, 1914, i, 124. 
and make of many, who would otherwise become helpless dependents, healthy self-sustaining citizens.

The economy of such a course has appealed already to four states: Minnesota, New York, Massachusetts, and Nebraska. The results attained have been excellent, and the work has met the urgent needs of a large class of handicapped children.

There are in New Jersey three standard institutions for crippled children, in Newark, Englewood and Orange; and several summer homes, as for instance, at Westfield and Atlantic City. But there is real need for a state hospital school in New Jersey.

The cost would not be large-entirely out of proportion to the results which would be obtained. Perhaps the crippled children may find some champions in the approaching Legislature.

\section{GRADUATION OF NURSES AT NEWARK HOME}

Graduation exercises of the nurses who had completed their course in the training school for nurses at the Home for Crippled Children, Newark, were held October 15, 1914.

Dr. Sidney A. Twinch, the surgeon-in-chief, presented the diplomas. Addresses were made by Rev. John S. Miller, rector of the House of Prayer, and Dr. Frank Pinneo.

\section{NEEDLEWORK AS AN INDUSTRY}

Industrial instruction in needlework given to crippled girls in Cleveland, under the auspices of the Sunbeam Circle, is described in a recent issue of the Social Bulletin issued by the Cleveland Federation of Charity and Philanthropy.

The industrial work of the Sunbeam Circle started on an entirely new enterprise last summer. Through weekly sewing lessons given by the Board of Education to grade scholars, a group had made great headway in practical sewing. Other crippled girls in all parts of the city, some once pupils under Sunbeam Circle's former school work, seemed more adapted to sewing than other work.

With this material, during the months of July and August, the Circle conducted a sewing school. Two teachers not only taught the 

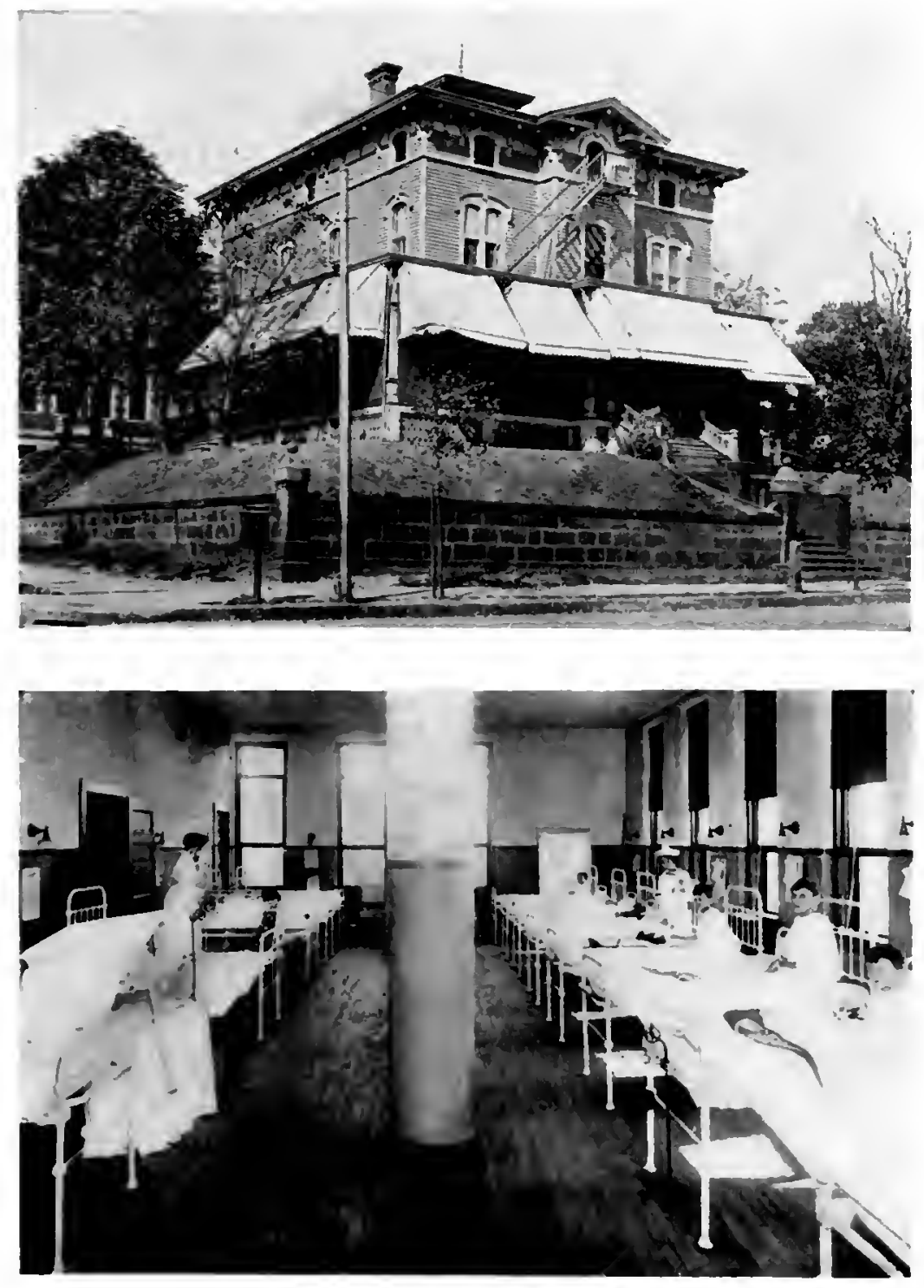

1. OLD BULLDING SHOWTG PORCH WARDS

II. ONE OF THE WARUS IN THE NEW BUILBSO 

sewing but interested themselves particularly in the physical condition of the class.

The girls met five days of every week from ten until three o'clock at a house in the East End. The girls who depended on crutches and could not go in the car were taken back and forth by auto and omnibus.

The sewing was done almost entirely out of doors. Lunches were brought by the girls and eaten in the garden. Milk and cocoa were provided for them. Flowers were picked daily and taken home.

As a result, the girls are undoubtedly in better condition to meet the winter's work, both in health and in spirits, and their enthusiasm and amount of clothes made have quite exceeded expectations.

An endeavor to make this training productive is now being made. At the beginning of the regular term, the younger girls returned to school, but the older ones, with one teacher, are continuing work. They have turned their quarters at 424 Quinby Block into a shop, and are soliciting customers for their work. Children's clothes-their specialty-are already on sale.

SCHOOL LUNCHES FOR CRIPPLES

Beginning with the fall term the Cleveland Board of Education has assumed responsibility for the provision of school lunches for crippled children. This work was done last year by the Sunbeam Circle.

\section{OBJECTION TO HOSPITAL ERECTION}

The House of St. Giles the Cripple, now located in Garden City, L. I., recently raised funds to build a city hospital in Brooklyn. Work was begun on a site located at Brooklyn Avenue and President Street, and the excavation for the cellar had been completed when legal objection was made by the residents of the locality. Litigation over the matter is now pending.

SALE BY EAST SIDE FREE SCHOOL

The Crippled Children's East Side Free School held its annual exhibition and sale of goods made by the pupils at Delmonico's, December 8, 1914. 


\section{BREARLEY LEAGUE EXHIBITION}

The Brearley League, New York, held an exhibition and fair for the benefit of its trade classes for cripples on December 5,1914 , at the Brearley School. The exhibition included specimens of the work of Brearley School graduates. Jewelry made by the boys and embroidery executed by the girls in the trade classes were on sale.

\section{BENEFIT FOR ORTHOPEDIC W'ARD}

For the benefit of the orthopedic ward of the Post Graduate Hospital, New York, the Ladies' Auxiliary of the ward gave a bazaar and dansant at Sherry's on December 21. There were various booths for the sale of Christmas gifts, exhibition and general dancing, and fortune telling. For the children there were a Christmas tree, games, and 'grab bags.'

\section{CONSTRUCTION OF THE HOSPITAL BUILDING}

The experience gained in the erection of the splendid structure of the Hospital for the Ruptured and Crippled, New York, and the results of extended observation and study have been set forth by Mr. Oliver $\mathrm{H}$. Bartine, superintendent of the hospital named, in a most scholarly paper delivered before a meeting of the Hospital Alliance at the New York Academy of Medicine, December 1.

Mr. Bartine advised a systematic scheme to develop the plans for the hospital under the direction of a building committee assisted by an advisory committee. The membership of the latter, being representative of the various branches of hospital activity, makes available the experience gained in each branch of work. On this committee should be the superintendent, the surgeon-in-chief, president of the Medical Board, architect, consulting engineer, operating engineer, and probably the directress of nurses.

The various problems encountered in the planning and erection of a hospital building were fully discussed. 


\section{MAKING CURES PERMANENT}

Following up children in their homes after discharge from the institution is an important part of the work of Rainbow Hospital in the outskirts of Cleveland. The following extract from the report of a special worker throws light on the methods employed:

Another cured case, or rather nearly cured, without deformity, is Helen, eight years old, one of our tubercular spines. In our annual report for 1911, three pictures of Helen were printed, showing her condition when she came to us, under treatment, and nearly cured. Helen remained at Rainbow one year and a half. Now she is wearing her brace only part of each day as a matter of precaution, and it is expected that she will soon leave it off entirely. All the orthopedic cases discharged during the last six months are reporting regularly to the clinic, their braces are inspected in the home at least every two weeks, and $\mathrm{x}$-rays and tracings are taken whenever necessary. By these methods we hope to prevent the children from returning to Rainbow, in order to begin treatment all over again. The ideal toward which we are all working is to keep each child at Rainbow until he is cured, but until this is possible, these methods seem to be the nearest approach.

\section{DEDICATION OF NEW DISPENSARY BUILDING}

The new dispensary building of the Hospital for Deformities, and Joint Diseases, at 41 East 123d Street, New York City, was dedicated on the afternoon of November 3. Addresises were made by Dr. Abraham Jacobi, Adolph Lewisohn, Judge Julius M. Mayer, Jacob H. Schiff, Lewis Straus, Louis Wiley, and Emanuel M. Gattle. The following statement appeared in the New York Evening Post:

During the eight years of the hospital's existence the number of treatments has increased from 9,471 to 45,633 , and the new cases from 1,212 to 4,505 . The new dispensary building, which is six stories in height, is equipped for the manufacture of mechanical braces and shoes for patients afflicted with deformed feet, and, among other things, 
with rooms for the application of plaster in the treatment of paralytic distortions, bowlegs, and other similar diseases, and apparatus for the treatment by massage and electricity of the various types of infantile paralysis.

It also contains two gymnasiums, chemical, bacteriological, and pathological laboratories, an operating room, constructed on modern lines of aseptic surgery, and in conjunction a plaster room, anæsthetizing, sterilizing, $\mathrm{X}$-ray, and photographic rooms.

\section{WORK OF THE BOSTON SCHOOL}

The Industrial School for Crippled and Deformed Children, Boston, a non-resident, private, primary and industrial school, is one of the American pioneers in work for cripples. Its annual report $^{3}$ which has just appeared is an unusually informing document and, as it presents conclusions derived from long experience, should be of general interest. There follows an extract from the report of the trustees:

The Industrial School for Crippled and Deformed Children has been in existence long enough, short though its period really is, to be able to record accomplishments that are definite and unusual among the results of charity organization in this city. Starting as a small elementary school for a group of crippled children, it has instituted a systematic course of primary school instruction abreast of the standard set for public schools; it has developed industrial training classes; it has set up and equipped shops for practical work; it has furnished work in these shops to graduate crippled workers; and it has succeeded in aiding graduates to find working positions.

The school now has an alumni association which meets annually, and covers in the reports of these meetings the varied activities of the former pupils of the school. These reports demonstrate clearly just how serviceable the school's training has been to the pupils, and also how much aid has been given to the graduates in finding work.

The transportation of pupils from their homes to the school and back again daily has been found to be of great value to the proper

${ }^{3}$ Industrial School for Crippled and Deformed Children. Boston. Twentieth annual report, 1914. 
conduct of the institution, though it provides a large item of expense. In this way only can the school be brought within the reach of many pupils who would otherwise be obliged to remain without school instruction. In this way only parents of the pupils are able to give their children home care while they are enjoying the advantages of a school training.

In like manner the policy of furnishing to each child a hearty midday meal has been justified, after careful study by the committee in charge of the problem. Most of the children with whom the school started were afflicted chiefly by tuberculous bone affection, and such cases have continued to furnish a large proportion of the pupils. It is well known that crippled children generally, and those suffering from bone tuberculosis especially, need a more substantial diet than is given ordinarily to school children. This fact raises the cost of the school's noon meal, but only emphasizes the need of it.

Most gratifying results have followed also the adoption of special gymnastics as part of the school curriculum; the improvement in the condition of the children is readily noted. And after one year of use, the value of the large fresh-air schoolroom, the gift of a friend, has been shown as clearly.

The industrial work done at the school falls within two categories: manual training supplementary to school work for the pupils of the primary and grammar classes; and trade classes for girls and boys over the age of fifteen. The latter classes, the workers in which receive pay as soon as they become proficient, come under the jurisdiction of the Industrial Committee, an excerpt from whose report is appended:

The cobbling classes, which have hitherto taken no industrial pupils, encourage us to develop a cobbling department. The old shoes cobbled find a ready sale to the families of our children, and the trade seems an eminently practical one for the cripple.

The sewing department receives orders for children's dresses and shirt waists sufficient to keep the girls busy. The fancy articles made at odd times find a ready sale whenever we are able to offer them to the public.

Financially, the cane-seating and basket department makes a good 
showing. The chairs come steadily, and give employment, but there is more money in the baskets when we can get a sale. For both workmanship and variety we may be justly proud of them.

The printing department has been successful as usual in a business way, and its pupils gain in efficiency each year.

\section{FRANCIS J. COTTING}

In the death during the past year of Mr. Francis J. Cotting, president of the Industrial School for Crippled and Deformed Children, Boston, that institution lost a most energetic worker in the cause. Himself a cripple, he gave largely of his time and money to further the interests of crippled children. In referring to his personality and work, the annual report of the institution just referred to speaks of him as follows:

No lesson to the handicapped could be more helpful than a statement of his life and work. Those wishing to aid the crippled can find no greater stimulus for their efforts than the example of one who, overcoming the obstacles of physical affliction, was so successful in the work of helping those afflicted like himself.

Francis J. Cotting was born in Brookline, Mass., on September 4,1865 . At an early age he was stricken with a severe form of crippling and paralytic affection in a manner to condemn him to lifelong suffering and the imprisonment to a wheel chair. His activities became limited to those possible through the help of attendants. He was, however, blessed with an enviable temperament, a pleasant nature, great courage, and unusual qualities of good sense and judgment; he had with these qualities an ability for painstaking devotion to detail which would have been of the greatest value in the world of affairs.

He made his life one of unusual usefulness. All his ability was brought into play in the work which he undertook-that of developing an industrial school for crippled children.

To the more recent friends of the school it would be a surprise if they could realize the condition of the institution when Mr. Cotting first became connected with it. It is a happy fact that he lived to see the result of his efforts presented so evidently that he could not, even 
with all his modest disparagement of his own ability, escape from the conclusion that his service in the work of aiding the handicapped and crippled was of the greatest value.

Resignation is a valuable quality in affliction, but a quiet determination to utilize the utmost that remains is the lesson most needed by the crippled, and this lesson was taught in the life of our late President. His achievement was unusual. In less than fifteen years of personal exertion he gradually built up this school from small beginnings to its present position of great usefulness. He demonstrated not only the need of the work, but showed also that by a careful administration every dollar contributed was wisely and economically used.

To win success when gifted with capable abilities is admirable, but to achieve nobly when hampered by harassing disabilities is heroic. This was done by Francis J. Cotting, and his work will live.

\section{CRIPPLES SUBJECT OF CLUB MEETING}

A monthly meeting of the Monday Club, an organization of professional social workers in New York City, was held November 30, 1914, at the Hospital for the Ruptured and Crippled. The members convened during the late afternoon and thoroughly inspected the new building of the Hospital. Dr. Hastings $H$. Hart of the Russell Sage Foundation, who is president of the Club, then gave a concise lantern slide talk on institutions for cripples in the United States.

The visitors next had supper as the guests of the Hospital and later assembled to hear papers and discussion in the waiting room of the dispensary. The speakers were representative of the three largest orthopedic institutions in the city.

Dr. Virgil P. Gibney, surgeon-in-chief of the Hospital for the Ruptured and Crippled, welcomed the members of the club and spoke delightfully of his reminiscences of long years of service in the treatment and cure of crippled children.

Dr. Russell A. Hibbs, surgeon-in-chief of the New York Orthopædic Hospital, urged the importance of early treatment for cripples. He said that in studying the cripples' needs it 
would simplify matters to divide them into three classes. First, those crippled from joint tuberculosis; second, those crippled from infantile paralysis; third, a large class crippled by a variety of causes, such as congenital deformity, disease, and accident.

The one general fact to be emphasized is that if their surgical needs are met very early in life and early in disease, many can be restored to a socially normal status. The methods of doing this are well known; the only trouble is that it is not being done for any considerable number of children.

Dr. Henry W. Frauenthal, surgeon-in-chief of the Hospital for Deformities and Joint Diseases, spoke of the great service that was being rendered by the orthopedic dispensaries. He drew attention to the superiority of American over European provision in this regard. Social workers could be of great assistance by sending promptly to the dispensaries persons in need of their care.

A gencral discussion took place after each speaker had finished. Among those who took part were Dr. Charles H. Jaeger, Miss Florence Campbell, and Mr. Douglas C. McMurtrie.

\section{GYMNASTICS FOR CRIPPLED CHILDREN}

Gymnastics as a feature of value in the care of crippled children has been discussed by Dr. Ewerhardt of St. Louis, in a recent article. ${ }^{4}$ After speaking of the large numbers of cripples to be found in any urban community he states as follows:

Properly selected and carefully applied gymnastic exercises are a valuable adjunct in the treatment of some of the many types of deformities. They favorably influence muscular and nerve structure, restore impaired muscular action, stimulate the actual functions of the body and thus improve bodily efficiency. Motor training educates a muscular sense. Numerous perceptions, clear-cut and well-defined, are thus formed regarding distance, direction, weight, force, resistance

"F. H. Ewerhardt. Gymnastics in relation to crippled children. American Physical Education Reviezv, Springfield, Mass., 1914, xix, 563-567. 
and effort, which, without motor training, would remain dim and vague. Exercise, therefore, may justly be regarded as a valuable therapeutic agent in attempts to restore physical and mental balance in unfortunate cripples.

It must, however, be borne in mind that in some cases of deformities, particularly the active tubercular, exercise is absolutely contraindicated and a violation of this principle might seriously aggravate the condition.

The author urges that if gymnastics be given at all that the time allowed be adequate to make possible concrete results. Recreative or educational gymnastics, while highly useful, do not meet the special needs of the physically defective child. More specialized corrective gymnastics should be provided for cases which will profit by it. Laying the main emphasis on physical betterment will increase the capacity of the individual for self-support, thus working an economic advantage.

The two types of gymnastics can, however, be very properly combined and the corrective work can be identified with recreational and educational features. The latter part of the paper goes into exercise in relation to the limitations imposed by various surgical diagnoses and discussed the advantage of systematic gymnastics in the therapeusis of certain diseases.

\section{HOSPITAL ALUMNI MEET}

The second annual meeting of the Society of Alumni of the Hospital for the Ruptured and Crippled, New York, was held at the Hospital December 29 and 30. The programme included operations, demonstrations of cases, luncheons, and a reunion dinner. The officers of the Society are: Dr. Virgil P. Gibney, president; Dr. Clarence Starr, vice-president; Dr. Charles Ogilvy, secretary-treasurer.

\section{ADDITION OF AN INCLINE}

The use of inclines instead of stairways in homes for crippled children seems very general. A new incline leading from the 
ground to the platform between the solarium and schoolhouse has just been added at the Home of the Merciful Saviour, in Philadelphia. The cost of the improvement was two hundred dollars. This institution completed its thirty-second year November 1, 1914.5

\section{A MOVING PICTURE FILM}

Among the juvenile films issued by one of the large concerns making moving picture machines for home use is one dealing with two crippled children. By reason of its popular circulation the theme is of interest. The synopsis of the film, which is entitled 'The Dream Fairy,' is as follows:

Tim, a lame newsboy, does not believe in fairies. Sylvia, a daughter of a wealthy man, is also a cripple. When she learns that her parents have secured the services of a great surgeon, who has promised to cure her, she falls asleep and dreams that a fairy offers her three wishes. Her thoughts go out to little Tim whom she has met on the street and who has declared his unbelief in fairies. She unselfishly wishes that she might visit his home and then that Tim might be cured. She is warned to make her own cure the object of her last wish, but instead wishes that Tim's poverty-stricken family might prosper. Then she awakens and tells her dream to her parents, and, miracle of miracles, all her wishes are fulfilled and she is cured besides. Now Tim believes in fairies.

'Home of the Merciful Saviour. Philadelphia. Thirty-second annual report, 1914. 


\section{BIBLIOGRAPHICAL NOTES}

Becher, Paul. Krüppelheim und Schule mit besonderer Berücksichtigung der Verhältnisse des Zwickauer Krüppelheims. Zeitschrift für Krüppelfürsorge, Hamburg and Leipzig, 1912, $\mathrm{v}$, 30-35.

BIEsalski, KonRad. Krüppelfürsorge. In Soziale Kultur und Volkswohlfahrt während der ersten 25 Regierungsjahre Kaiser Wilhelm II. Berlin, 1913. p. 469-478.

Biesalski, Konrad. Die moderne Krüppelfürsorge in Deutschland. Zeitschrift fïr ärztliche Fortbildung, Jena, 1913, x, 155-159.

Biesalski, Konrad. Statt und Krüppelfürsorge in Preussen. Zeitschrift für Krïppelfïrsorge, Hamburg and Leipzig, 1914, vii, 3-16.

Blanchard, Wallace. The state care of crippled children. Chicago Medical Recorder, 1914, xxxvi, 162-167.

Champness, Mary. Birmingham and District Cripples' Union. The Child, London, 1911-1912, ii, 506-510.

Charity Organisation Society. The epileptic and crippled child and adult. A report on the present condition of these classes of afflicted persons with suggestions for their better education and employment. London, 1893.

Crippled (the) child. (Editorial). Youth's Companion, Boston, 1914, lxxxviii, 506.

DAM, CH. L'assistance aux estropiés et les écoles d'estropiés. Progrès Médical Belge, Brussels, 1914, xvi, 25-29. 
Fellows, Reginald B. St. Vincent's Cripples' Home, Eastcote. The Child, London, 1912-1913, iii, 248-257.

Flower, Ernest. Sir William Treloar, Bart. The Child, London, 1911-1912, ii, 576-580.

Descriptive of the establishment and work of the Lord Mayor Treloar's Cripples' Hospital and College.

FöRSTER. Zentralisation der Krüppelarbeitsstätten. Zeitschrift für Krüppelfïrsorge, Hamburg and Leipzig, 1913, vi, 153-155.

FürstenheIM, W. Zur Lehre von der Wechselwirkung zwischen körperlicher und geistiger Schwäche im Kindesalter. Zeitschrift für Krüppelfürsorge, Hamburg and Leipzig, 1912, $\mathrm{v}, 10-25$.

Fuessle, Newton A. Making new lives for children. Collier's, New York, 1914, lii, March 14, pp. 21; 24.

Good Shepherd Home. Allentown, $P a$. The sixth anniversary of the Good Shepherd Home. Allentown, Pa., 1914.

Gottstein, J. F. Das "Krüppelheim" in Reichenberg. Prager Medizinische Wochenschrift, 1913, xxxviii, 218-226.

Great Britain. Board of Education. Annual report for 1912 of the Chief Medical Officer of the Board of Education. London, 1913 [Cd. 7184].

Section X. The special schools for blind, deaf, and physically defective children. p. 211-228.

Haglund, Patrik. Barnförlamningsföljderna och deras behandling. Stockholm, 1913.

Chapter XII. Om barnförlamningsföljderna från social synpunkt.

(Infantile paralysis in its social aspect.)

Bibliography appended. 
Haglund, Patrik. Huru bör "vanföresaken" ordnas i Sverige? Reflexioner från medicinsk synpunkt. Almänna Svenska Läkartidningen, Stockholm, 1904, i, 65-72.

Haglund, Patrik. Om vanförevård. Social-medicinsk studie. Stockholm, 1906.

Haglund, Patrik. Om vanförhet och vanförevård. Till de vanföras, deras målsmäns och allmanhetens tjänst. Stockholm, 1912.

Hoeftman, H. Wiederherstellung der Arbeitsfähigkeit durch Prothesen, mit kinematographischen Demonstrationen. Zeitschrift für orthopädische Chirurgie, Stuttgart, 1913, xxxiii, 112-130.

Kimmins, Mrs. C. W. Child welfare and the Guild of the Brave Poor Things. The Child, London, 1913-1914, iv, 257-262.

KIRK, Sir JoHs. The holiday work of the Ragged School Union. The Child, London, 1912-1913, iii, 1020-1026.

Kirschstein, Johannes. Die neue Kruppel-Heil- und Lehranstalt für Ostpreussen in Königsberg. Zeitschrift fïr Krüppelfürsorge, Hamburg and Leipzig, 1913, vi, 146-153.

Kronacher, Berthold. Die Beratungsstelle für krüppelhafte Kinder in Nürnberg. Zeitschrift für Krüppelfürsorge, Hamburg and Leipzig, 1914, vii, 78-81.

Künne, Bruno. Das Phytin bei Krüppelleiden. Medizinische Klinik, Berlin, 1913, ix, 215-216.

LANDWEhr, H. Das erste kommunale Krüppelheim. (Die Stiftung Dr. Dormagen der Stadt Köln.) Zeitschrift für Krüppelfürsorge, Hamburg and Leipzig, 1913, vi, 294-300. 
Liverpool. Education Committee. Report on the medical inspection of school children for the year 1913. Liverpool, 1914. Special schools, p. 68-71.

London. London County Council. Minutes of proceedings, January to June, 1913. London, n: $d$.

Part I contains various memoranda regarding acts by the Education Committee relative to special schools for physically defective children. The various transactions are given in minute detail.

Major, Gustav. Lassen sich die Grundsätze der Heilerziehungsheime auf Krüppelheime übertragen. Zeitschrift für Krüppelfürsorge, Hamburg and Leipzig, 1913, vi, 283-291.

McMurtrie, Douglas C. Eliminating the cripple from the community; concerning the Newark Home for Crippled Children. 'New Jersey,' Jersey City, 1914, i, 116-121.

Muensterberg, E. Krüppelfürsorge. Zeitschrift für das Armenwesen, Berlin, 1910, xi, 65-76.

Muskat, Gustav. Das Kopenhagner Krüppelheim. Deutsche medizinische Wochenschrift, Leipzig, 1908, xxxiv, 426-427.

A translation of this article appeared in the last issue of the JourNal.

Neve, Oscar. Krüppelfürsorge, Volkswohlfahrt und Volkswirtschaft. Archiv für Volkswohlfahrt, Berlin, 1907-1908, i, 16-31.

A bibliography is appended to this article.

Nitzsche, ReInhold. Die sächsische Krüppelfürsorge und das Leipziger Heim für gebrechliche Kinder. Zeitschrift für Krüppelfürsorge, Hamburg and Leipzig, 1913, vi, 227-237.

OrR, H. Winnetr. The industrial education of the crippled and deformed. Western Medical Review, Omaha, Neb., 1912, xvii, 241-243.

A reprint of this article appeared in the last issue of the JournaL. 
No. 4 .

OrR, H. Winnett. Tuberculosis in children. [Lincoln, Neb. 1908].

A folder for popular distribution.

Physically defective school. Saturday Review, London, 1908, cvi, 291-292.

Plothow, Anna. Die Ästhetik im Leben des Krüppels. Zeitschrift für Krüppelfürsorge, Hamburg and Leipzig, 1914, vii, 43-46.

ReEves, Edith. Care and education of crippled children in the United States. Introduction by Hastings H. Hart, LL.D. (Russell Sage Foundation publication). New York, 1914.

REsmaRK, Th. Die Krüppelfürsorge in Schweden. Zeitschrift für Krüppelfürsorge, Hamburg and Leipzig, 1913, vi, 214-226.

Scherb. Die Anstalt Balgrist in Zürich 8. Schweizerische Heil- und Erziehungsanstalt für krüppelhafte Kinder und orthopädische Poliklinik. Zeitschrift für Krüppelfürsorge, Hamburg and Leipzig, 1913, vi, 134-139.

Smith, Kitty. How I made hands of my feet. Ladies' Home Journal, Philadelphia, 1911, xxviii, March 1, p. 19.

Svenska Vanföreanstalternas Centralkommitté. Stockholm, Sweden. Flygblad N:o 1. Stockholm, 1913.

A general description of how cripples are cared for in Sweden.

Concerning hospitals and schools for cripples.

Stockholm, 1913.

Concerning the number of cripples in Sweden. 
To the medical men of Sweden.

Stockholm, 1914.

Flygblad N:o 5.

To the nurses of Sweden.

Stockholm, 1912.

Till Sveriges Barnmorskor! Flygblad N:o 6.

To the midwives of Sweden.

- Till Sveriges Folkskolelärare och -lärarinnor! Flygblad N:o 7. Stockholm, 1912.

To the men and women teachers of Sweden.

- Till Sveriges kommunal- och Fattigvårdsordförande! Flygblad N:o 8. Stockholm, 1914.

To the communal and poor officials of Sweden.

1913.

To the clergymen of Sweden.

Stockholm, 1912.

To the medical gymnasts of Sweden.

Tuckerman, J. E. Management, maintenance and efficiency of the School for Cripples in Cleveland. Bulletin of the American Academy of Medicine, Easton, Pa., 1913, xiv, 95-98.

Ulbrich, Martin. Wie ich ein Handwerkheim für verkrüppelte Lehrlinge bauen würde. Zeitschrift für Krüppelfürsorge, Hamburg and Leipzig, 1913, vi, 110-116.

WaChSNER, Fritz. Orthopädische Jugendfürsorge. KinderArzt, Leipzig, 1914, xxv, 49-54. 
WaChSNER, Fritz. Orthopädische Jugendfürsorge und körperliche Erziehung. Medizinische Reform, Berlin, 1914, xxii, 261-265.

What I faced in my life. Ladies' Home Journal, Philadelphia, 1913, xxx, February, 13; 64.

The autobiography of a crippled girl triumphant over her handicap.

WürTz, Hans. Alkoholfreie Krüppelerziehung. Zeitschrift für Krüppelfürsorge, Hamburg and Leipzig, 1913, vi, 273-283.

Würtz, Hans. Ein Beitrag zur Begrundung der Krüppelpsychologie. Zeitschrift für Krïppelfürsorge. Hamburg and Leipzig, 1914, vii, 16-42.

Würtz, Hans. Krüppeltum und Lebensfreude. Zeitschrift für Krüppelfürsorge, Hamburg and Leipzig, 1913, vi, 83-93.

WÜRTZ, Hans. Die Schulabteilung der Berlin-Brandenburgischen Krüppel-Heil- und Erziehungsanstalt. Zeitschrift für Kriippelfürsorge, Hamburg and Leipzig, 1913, vi, 139-146.

Würtz, Hans. Die Selbsttätigkeit als Prinzip in der Krüppelerziehung. Zeitschrift für Krüppelfürsorge, Hamburg and Leipzig, 1913, vi, 182-199. 
18 


\section{INDEX}

There follows a dictionary index to the text of the volume. Subjects are set in roman letters, geographical divisions and cities in italics, and proper names in capitals and small capitals. Individual institutions are listed under the city or town of their location. The formal titles of articles and notes may be found on the contents pages preceding individual issues.

American Open Air School Association, 98.

American Orthopedic Association, 98.

Allentown, Pa., Good Shepherd Home, $63,91,145$.

Art, cripples in, 76.

Artificial limbs, in U. S. Service, 144.

Atchison, Kan., State Orphans' Home, 142.

Atlantic City, N. J., Children's Seashore House for Invalid Children, 64.

BALDWIN, Louise, 54, 90.

Baltimore, $M d$., public school classes, 88 .

BarNes, Mabel Irving, 73.

Bartine, Oliver H., 190.

Basketry, course in, 45.

Berlin, institution for cripples, 135.

Bibliographical notes, 109, 199.

Biesalski, Konrad, 161.

Blanchard, Wallace, 146.

Baston, Mass., Industrial School for Crippled and Deformed Children, 15, 45, 97, 192, 194.

industrial training around, 15.

Brooklyn, N. $Y$., new work in, 48 .

objection to building by House of St. Giles the Cripple, 189.

Brown, Edward F., 182.

Buffalo, N. Y., Wheel Chair Home for Incurables, 101.

Cane seating, course in, 45 .
Canlon, Mass., Massachusetts Hospital School, 129.

Central States Orthopedic Club, 49.

Chicago, Ill., public school classes, 56, 90.

Cleveland, Ohio, mutual alliance in, 52. public school classes, 139.

Rainbow Hospital, 191.

school lunches for crippled children, 189.

Sunbeam Circle, 188, 189.

Compensation Act, New York State, 175.

Construction, hospital building, 190 .

Copenhagen, institution for cripples, 115.

Cotting, Francis J., 194.

Country homes for crippled children in the vicinity of New York, 78.

Davis, Gwilym G., 5.

Denmark, Copenhagen institution, 115.

Detroit, Mich., public school classes, 140.

Driving fund, for crippled children, 62 , 89.

Editorial, on the crippled child, 138.

Education of crippled children, 5.

England, Liverpool public school classes, 153.

London public school classes, 150, 152. statistics of public school classes, 154.

Ewerhardt, F. H., 196.

Federation of Associations for Cripples, $3,21,92,132,175$. 
Feeding crippled school children, 182.

Fifteenth century painter of cripples, 76.

Fish, John E., 129.

Fish, Lilian Gilbert, 53.

France, Paris societies for cripples, 101.

Garden City, L. I., House of St. Giles the Cripple, 189.

Germany, Berlin institution, 135.

modern methods of care in, 161.

Munich institution, 104.

statistics and provision for care, 119.

Gymnastics, for crippled children, 155, 196.

Hardy, Grace F., 45.

Hawthorne, N. Y., Blythedale Home for Convalescent Tubercular Cripples, 97.

Hebden, Edwin, 88.

History, care for cripples, 26.

Federation of Associations for Cripples, 21.

Hospital social service, St. Louis, 61 .

Hyde Park, Mass., New England Peabody Home, 49.

Industrial training, 67, 125, 188.

about Boston, 14.

in the West, 142.

Industries that cripple their employees, 175.

Jaeger, Charles H., 67.

Joyce, R. S., 125.

Kansas, State Orphans' Home, 142.

Library, on care of cripples, 148.

Lincoln, Neb., Nebraska Orthopedic Hospital, 52.

Literature, cripples in, 130.

Liverpool, public school classes, 153.

London, public school classes, 150, 152.

McMurtrie, Douglas C., 27, 76, 82, 104, 119, 130, 175, 186.

Magazines, of institutions, 63.

Massachusetts, State Hospital School, 129.

Medical Record, editorial from, 99.

Mentally defective cripple, 82.
Minnesota, first state institution, 58.

Monday Club, meeting on cripples, 195.

Moving picture film, 198.

Munich. Königliche Zentralanstalt für Erziehung und Bildung krüppelhafter Kinder, 104.

Muskat, Gustav, 115.

Mythology and legend, cripples in, 130.

Nebraska, State Orthopedic Hospital, 52.

Needlework, as an industry, 188.

Negro crippled children, institution for, 60.

Newark, N. J., Home for Crippled Children, $186,188$.

New Jersey, need for state provision, 187.

New York City, Association for the Aid of Crippled Children, 73.

Brearley League, 54, 90, 190.

Children's Aid Society, 98.

country homes in vicinity of, 78.

Crippled Children's Driving Fund, 62, 89.

Crippled Children's East Side Free School, 97, 135, 189.

feeding crippled school children, 182.

Free Industrial School for Crippled Children, 53.

Hospital for Deformities and Joint Diseases, 191.

Hospital for the Ruptured and Crippled, 197.

Post Graduate Hospital, Ladies Auxiliary of Orthopedic Ward, 190.

Trade School of the Hospital of Hope, 67.

ORR, H. WinNetT, 43, 49, 52, 102, 142.

Paris, societies for cripples, 101.

Parsons, Marion A., 52.

Philadelphia, Pa., Home of the Merciful Saviour, 59, 101, 197.

House of St. Michael and All Angels, 60.

public school class, 106, 107.

Port Jefferson, L. I., St. Charles Hospital for Crippled Children, 98. 
No. 4 .

Prince Crossing, Ill., Country Home for Convalescent Children, 148.

Public school classes. Cleveland, Ohio, 139.

Detroit, Mich., 140.

Liverpool, 153.

London, 150, 152.

lunches in, 182, 189.

statistics of, in England, 154.

Railway cripple, 125.

RAKER, JoHN H., 91.

Rosseter, E. C., 90.

St. Louis, Mo., Hospital social service, 61.

St. Paul, Minn., Minnesota State Hospital, 58.

Seattle, Wash., Children's Orthopedic Hospital, 97.

Seligmann, Carrie M., 172.

Shop, for cripples' work, 172.
Shrady, Katharine W. A., 21.

Smith, Bertha, 89.

State care of cripples, 102, 146, 187.

Statistics, crippled children in Germany, 119.

cripples in U. S., 43.

Stenography, instruction in, 97.

Sweden, cripples in, 138.

Sweeney, Mrriam Townsend, 155.

Tarrylown, N. Y., Robin's Nest, 142.

Thorndike, Augustus, 14.

Thurston, Clara M., 49.

Trade training for adult cripples, 67.

See also: industrial training.

Truslow, Walter, 48.

U. S. Service, artificial limbs, 144.

Visiting nursing, 73.

War, cripples and, 132.

Welfare Commission for Cripples, 93. 


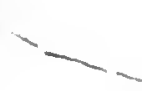




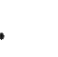

. 


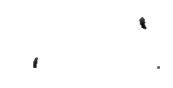

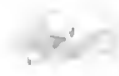
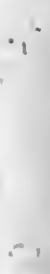

.

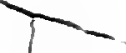


STORAGE 
